\title{
Recent advances in palladium-catalysed asymmetric 1,4-additions of arylboronic acids to conjugated enones and chromones
}

\author{
Jan Bartáček ${ }^{1}$, Jan Svoboda ${ }^{* 1}$, Martin Kocúrik ${ }^{1}$, Jaroslav Pochobradský ${ }^{1}$, \\ Alexander Čegan ${ }^{2}$, Miloš Sedlák ${ }^{1}$ and Jiří Váňa ${ }^{1}$
}

\author{
Review \\ Address: \\ ${ }^{1}$ Institute of Organic Chemistry and Technology, Faculty of Chemical \\ Technology, University of Pardubice, Studentská 573, 53210 \\ Pardubice, Czech Republic, and ${ }^{2}$ Department of Biological and \\ Biochemical Sciences, Faculty of Chemical Technology, University of \\ Pardubice, Studentská 573, 53210 Pardubice, Czech Republic \\ Email: \\ Jan Svoboda* - jan.svoboda@upce.cz \\ * Corresponding author \\ Keywords: \\ asymmetric reaction; boronic acid; conjugated enones; chromones; \\ enantioselective catalysis; Michael addition; Pd complexes
}

\author{
Beilstein J. Org. Chem. 2021, 17, 1048-1085. \\ https://doi.org/10.3762/bjoc.17.84 \\ Received: 14 February 2021 \\ Accepted: 17 April 2021 \\ Published: 10 May 2021 \\ Associate Editor: B. Stoltz \\ (C) 2021 Bartáček et al.; licensee Beilstein-Institut. \\ License and terms: see end of document.
}

\begin{abstract}
The transition metal (palladium)-catalysed asymmetric 1,4-addition of arylboronic acids to conjugated enones belong to the most important and emerging strategies for the construction of $\mathrm{C}-\mathrm{C}$ bonds in an asymmetric fashion. This review covers known catalytic systems used for this transformation. For clarity, we are using the type of ligand as a sorting criterion. Finally, we attempted to create a flowchart facilitating the selection of a suitable ligand for a given combination of enone and arylboronic acid.
\end{abstract}

\section{Introduction}

The asymmetric 1,4-addition of arylboronic acids to conjugated cyclic enones and chromones is a very important reaction nowadays. For illustration, the addition products are very promising in medicinal chemistry research [1-7] and in natural products total syntheses [8-16]. Chiral complexes of Rh [17-24] and Pd usually catalyse the reaction, however, palladium holds a special place in this area. There are several review articles partially covering this topic [25-31]. However, a comprehensive review is missing. In the following sections, we attempt to fill this gap. As a sorting criterion, the type of ligand (phos- phines, NHC-carbenes, bisoxazolines, pyridine-oxazolines, and miscellaneous) is used.

\section{Review}

Catalytic systems based on phosphine ligands

A pioneering work on the enantioselective addition of boronderived carbon nucleophiles to cyclic enones was published by the group of Miyaura et al. in 2005 [32]. Specifically, they have 
dealt with the addition of potassium aryltrifluoroborates to conjugated cyclic enones differing in ring size [32]. The catalysts PdL1a,b exhibited great conversion and enantioselectivities (up to $99 \%$ and up to $96 \%$ ee) for various combinations of nucleophiles and enones (Table 1). The authors also studied the possibility of the addition of boronic acids. The reaction of phenylboronic acid with 2-cyclohexenone catalysed by $5 \%$ of achiral $\left[\mathrm{Pd}(\mathrm{dppe})(\mathrm{PhCN})_{2}\right]\left(\mathrm{BF}_{4}\right)_{2}$ at $-5{ }^{\circ} \mathrm{C}$ gave the product in $21 \%$ yield. When 1 equiv of $\mathrm{BF}_{3} \cdot \mathrm{OEt}_{2}$ was added, the yield was increased to $74 \%$. This result led to the conclusion that in this catalytic system, much better results were obtained when aryltrifluoroborates are used. The system also worked well for linear enone electrophiles (entries 12-20, Table 1). The main disadvantage of this approach is the necessity of sub-zero temperatures $[32,33]$.

A follow-up report of the Miyaura group in 2007 provided an experimental protocol that allowed the addition of arylboronic acids instead of aryltrifluoroborates [34]. The previously used catalysts PdL1a,b were combined with additional silver salts $\left(\mathrm{AgBF}_{4}\right.$ or $\left.\mathrm{AgSbF}_{6}\right)$ that greatly accelerated the transmetalation of the boronic acid to Pd. This enhanced catalytic system showed a great turnover number (TON) up to 9,900. The authors described additions to cyclic substrates with high yields (90-99\%) and enantioselectivities (89-94\% ee; entries 1-5, Table 2). Also, a library of linear enones was tested giving

Table 1: First example of asymmetric addition of organoboron reagents to cyclic enones [32,33]

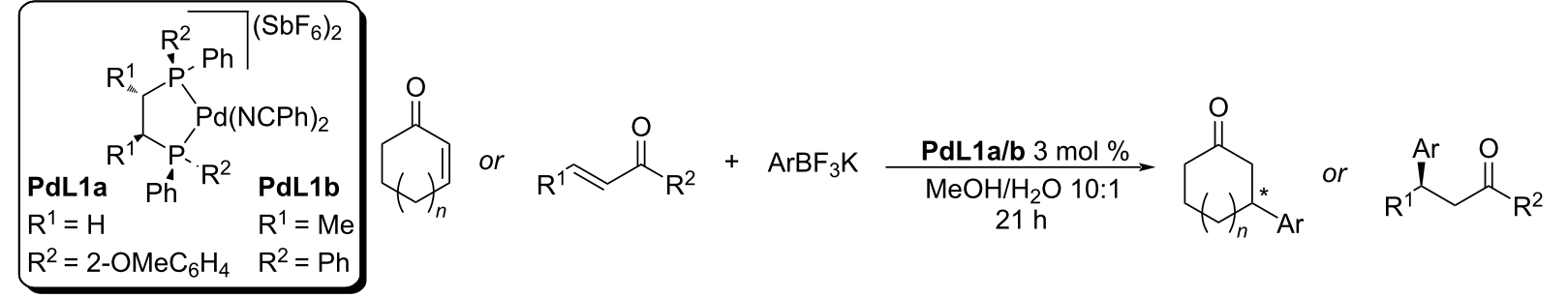

\begin{tabular}{|c|c|c|c|c|c|c|}
\hline entry & $\begin{array}{c}\text { cyclic substrate } \\
n\end{array}$ & $\mathrm{Ar}$ & cat. & temp. $\left({ }^{\circ} \mathrm{C}\right)$ & yield (\%) & ee $(\%)$ \\
\hline 1 & 0 & $\mathrm{Ph}$ & PdL1a & -5 & 60 & $95(S)$ \\
\hline 2 & 1 & $\mathrm{Ph}$ & PdL1b & -15 & 95 & $93(R)$ \\
\hline 3 & 1 & 4- $\mathrm{MeO}-\mathrm{C}_{6} \mathrm{H}_{4}$ & PdL1b & -5 & 89 & $85(R)$ \\
\hline 4 & 1 & $3-\mathrm{MeO}-\mathrm{C}_{6} \mathrm{H}_{4}$ & PdL1b & -15 & 97 & $95(R)$ \\
\hline 5 & 1 & 4-Me- $\mathrm{C}_{6} \mathrm{H}_{4}$ & PdL1b & -5 & 70 & $90(R)$ \\
\hline 6 & 1 & 3-Me- $\mathrm{C}_{6} \mathrm{H}_{4}$ & PdL1b & -5 & 96 & $93(R)$ \\
\hline 7 & 1 & $4-\mathrm{F}-\mathrm{C}_{6} \mathrm{H}_{4}$ & PdL1b & -5 & 99 & $92(R)$ \\
\hline 8 & 1 & $3-\mathrm{F}-\mathrm{C}_{6} \mathrm{H}_{4}$ & PdL1b & -15 & 81 & $96(R)$ \\
\hline 9 & 1 & $4-\mathrm{CF}_{3}-\mathrm{C}_{6} \mathrm{H}_{4}$ & PdL1b & -5 & 33 & $87(R)$ \\
\hline 10 & 1 & $4-\mathrm{CF}_{3}-\mathrm{C}_{6} \mathrm{H}_{4}$ & PdL1b & -5 & $66^{a}$ & $92^{\mathrm{a}}(R)$ \\
\hline 11 & 2 & $\mathrm{Ph}$ & PdL1b & -15 & 91 & $89(R)$ \\
\hline
\end{tabular}

\begin{tabular}{|c|c|c|c|c|c|c|c|}
\hline \multicolumn{8}{|c|}{ acyclic substrate } \\
\hline & $\mathrm{R}^{1}$ & $\mathrm{R}^{2}$ & & & & & \\
\hline 12 & $n-\mathrm{C}_{5} \mathrm{H}_{11}$ & $\mathrm{iPr}$ & $\mathrm{Ph}$ & PdL1a & -15 & 93 & 87 \\
\hline 13 & $n-\mathrm{C}_{5} \mathrm{H}_{11}$ & Cy & $\mathrm{Ph}$ & PdL1a & -15 & 98 & 88 \\
\hline 14 & $n-\mathrm{C}_{5} \mathrm{H}_{11}$ & $\mathrm{Ph}$ & $\mathrm{Ph}$ & PdL1a & -15 & 99 & 89 \\
\hline 15 & $\mathrm{iPr}$ & $\mathrm{Me}$ & 3- $\mathrm{MeO}-\mathrm{C}_{6} \mathrm{H}_{4}$ & PdL1a & -5 & 65 & 83 \\
\hline 16 & Cy & $\mathrm{Me}$ & $\mathrm{Ph}$ & PdL1a & -5 & 22 & 78 \\
\hline 17 & $\mathrm{Ph}$ & $\mathrm{Me}$ & $3-\mathrm{MeO}-\mathrm{C}_{6} \mathrm{H}_{4}$ & PdL1a & 0 & 90 & 95 \\
\hline 18 & $\mathrm{Ph}$ & $n-\mathrm{Bu}$ & $3-\mathrm{MeO}-\mathrm{C}_{6} \mathrm{H}_{4}$ & PdL1a & 5 & 91 & 99 \\
\hline 19 & $\mathrm{Ph}$ & $\mathrm{Ph}$ & $3-\mathrm{MeO}-\mathrm{C}_{6} \mathrm{H}_{4}$ & PdL1a & -5 & 94 & 97 \\
\hline 20 & 2-naphthyl & $\mathrm{Me}$ & $3-\mathrm{MeO}-\mathrm{C}_{6} \mathrm{H}_{4}$ & PdL1a & 0 & 73 & 96 \\
\hline
\end{tabular}

aNo water added. 
Table 2: Addition of arylboronic acids to enones accelerated by silver salts $[34,35]$.

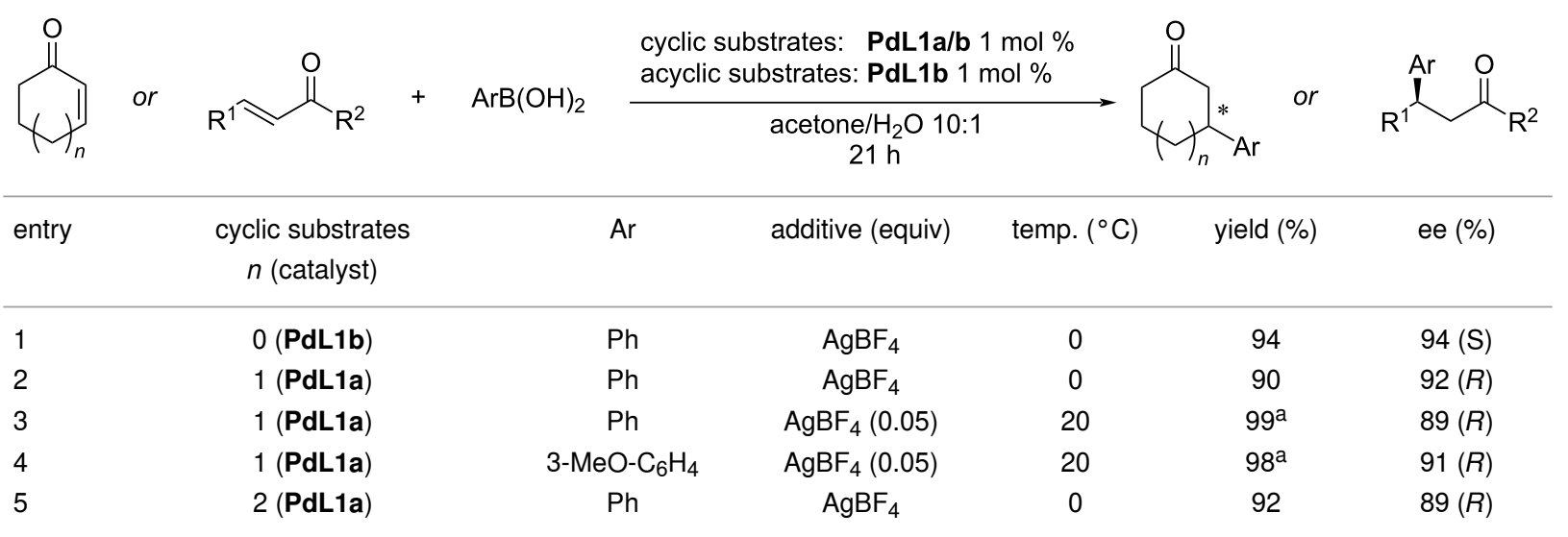

\begin{tabular}{|c|c|c|c|c|c|c|c|}
\hline \multicolumn{8}{|c|}{ acyclic substrates } \\
\hline & $\mathrm{R}^{1}$ & $\mathrm{R}^{2}$ & & & & & \\
\hline 6 & $\mathrm{Ph}$ & $\mathrm{Ph}$ & $4-\mathrm{Me}-\mathrm{C}_{6} \mathrm{H}_{4}$ & $\mathrm{AgBF}_{4}(0.1)$ & 20 & 73 & 95 \\
\hline 7 & $\mathrm{Ph}$ & $\mathrm{Me}$ & $3-\mathrm{Cl}-\mathrm{C}_{6} \mathrm{H}_{4}$ & - & 25 & 90 & 93 \\
\hline 8 & $\mathrm{Ph}$ & $\mathrm{Me}$ & 3-MeO- $\mathrm{C}_{6} \mathrm{H}_{4}$ & $\mathrm{AgBF}_{4}(0.1)$ & 0 & 96 & 95 \\
\hline 9 & $\mathrm{Ph}$ & $\mathrm{Me}$ & $4-\mathrm{MeO}-\mathrm{C}_{6} \mathrm{H}_{4}$ & $\mathrm{AgBF}_{4}(0.1)$ & 0 & 75 & 94 \\
\hline 10 & $\mathrm{Ph}$ & $\mathrm{Me}$ & $3,4-\left(\mathrm{CH}_{2} \mathrm{O}_{2}\right)-\mathrm{C}_{6} \mathrm{H}_{3}$ & - & 0 & 77 & 95 \\
\hline 11 & $\mathrm{Ph}$ & $\mathrm{Me}$ & 4-MeS- $\mathrm{C}_{6} \mathrm{H}_{4}$ & $\mathrm{AgBF}_{4}(0.1)$ & 25 & $<10$ & - \\
\hline 12 & $\mathrm{Ph}$ & $\mathrm{Me}$ & $4-\mathrm{Ac}^{-} \mathrm{C}_{6} \mathrm{H}_{4}$ & - & 0 & 95 & 93 \\
\hline 13 & $\mathrm{Ph}$ & $n-\mathrm{Bu}$ & $3-\mathrm{MeO}-\mathrm{C}_{6} \mathrm{H}_{4}$ & $\mathrm{AgBF}_{4}(0.1)$ & 0 & 66 & 99 \\
\hline 14 & $\mathrm{Ph}$ & $\mathrm{iPr}$ & $3-\mathrm{MeO}-\mathrm{C}_{6} \mathrm{H}_{4}$ & $\mathrm{AgBF}_{4}(0.1)$ & 0 & 80 & 95 \\
\hline 15 & $\mathrm{Ph}$ & Cy & $3-\mathrm{MeO}-\mathrm{C}_{6} \mathrm{H}_{4}$ & $\mathrm{AgSbF}_{6}(0.05)$ & 0 & 93 & 95 \\
\hline 16 & $\mathrm{Ph}$ & $\mathrm{Ph}$ & $3-\mathrm{MeO}-\mathrm{C}_{6} \mathrm{H}_{4}$ & $\mathrm{AgBF}_{4}(0.1)$ & 0 & 86 & 97 \\
\hline 17 & $\mathrm{Ph}$ & $\mathrm{Ph}$ & $4-\mathrm{Me}-\mathrm{C}_{6} \mathrm{H}_{4}$ & - & 0 & 91 & 95 \\
\hline 18 & $\mathrm{Ph}$ & $4-\mathrm{MeO}-\mathrm{C}_{6} \mathrm{H}_{4}$ & $3-\mathrm{MeO}-\mathrm{C}_{6} \mathrm{H}_{4}$ & $\mathrm{AgSbF}_{6}(0.1)$ & 0 & 73 & 95 \\
\hline 19 & $\mathrm{Ph}$ & $3-\mathrm{NO}_{2}-\mathrm{C}_{6} \mathrm{H}_{4}$ & 3-MeO- $\mathrm{C}_{6} \mathrm{H}_{4}$ & $\mathrm{AgSbF}_{6}(0.2)$ & 0 & 44 & 92 \\
\hline 20 & $4-\mathrm{MeO}-\mathrm{C}_{6} \mathrm{H}_{4}$ & $\mathrm{Ph}$ & $3-\mathrm{MeO}-\mathrm{C}_{6} \mathrm{H}_{4}$ & $\mathrm{AgBF}_{4}(0.1)$ & 0 & 75 & 99 \\
\hline 21 & 2-naphthyl & $\mathrm{Me}$ & $3-\mathrm{MeO}-\mathrm{C}_{6} \mathrm{H}_{4}$ & $\mathrm{AgBF}_{4}(0.1)$ & 0 & 99 & 96 \\
\hline 22 & 2-BnO-5-Me- & $\mathrm{Me}$ & $\mathrm{Ph}$ & - & 0 & 97 & 96 \\
\hline 23 & $\mathrm{C}_{6} \mathrm{H}_{3}$ & $\mathrm{Ph}$ & $\mathrm{Ph}$ & - & 0 & 86 & 98 \\
\hline 24 & $n-\mathrm{C}_{5} \mathrm{H}_{11}$ & $\mathrm{Me}$ & $\mathrm{Ph}$ & $\mathrm{AgBF}_{4}$ & 0 & 99 & 80 \\
\hline
\end{tabular}

aReaction time: $48 \mathrm{~h}$.

excellent yields and enantioselectivities in most of the cases (with up to $99 \%$ yield and $99 \%$ ee; entries 6-24, Table 2). Several substrates did not even require the addition of $\mathrm{Ag}(\mathrm{I})$ salts to achieve high yields (entries 7, 10, 12, 17, 22, and 23, Table 2) [34,35].

An interesting finding was that $\beta$-(2-hydroxyaryl)enones underwent cyclization to ketals (chromanols) after the addition of boronic acid. The prepared chromanols afforded the chromenes through elimination upon treatment with $p-\mathrm{TsOH}$. A series of different $\beta$-(2-hydroxyaryl)enones and boronic acids was tested and provided the substituted chromenes in excellent yields (89-94\%) and enantioselectivities (95-99\% ee; Table 3). It is worth mentioning that a free phenolic hydroxy group did not interfere with the Pd complex and did not affect the enantioselectivity of the reaction.

The authors also demonstrated that the product mixture obtained after the addition of the boronic acid to the $\beta$-(2-hydroxyaryl)enone could be oxidized to afford optically pure 4-phenylchroman-2-one (Scheme 1).

Also in 2007, Miyaura and co-workers presented the synthesis of enantioenriched 1 -aryl- $1 H$-indenes by a tandem 1,4 -addition of arylboronic acids to enones and aldol condensation [36]. The catalytic system for this transformation was adapted from 
Table 3: Synthesis of chromenes by the 1,4-addition of boronic acids to $\beta$-(2-hydroxyaryl)enones [34].

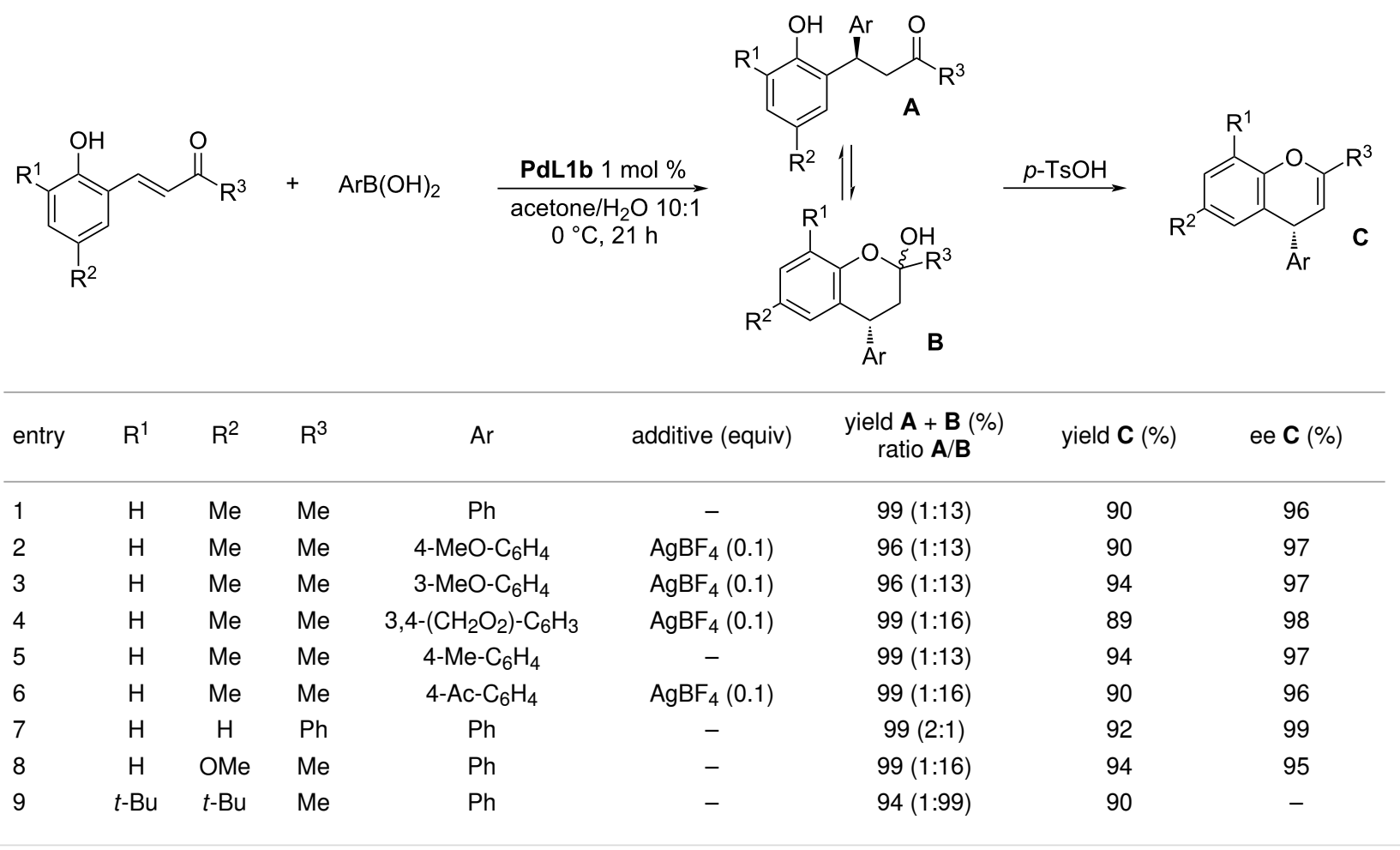

$$
\text { (33\%) }
$$

Scheme 1: Synthesis of optically pure 4-phenylchroman-2-one [34].

earlier works [34,36] and included the addition of a $42 \%$ aqueous solution of $\mathrm{HBF}_{4}$ that facilitated consequent cyclization. A series of various $\beta$-(2-acylphenyl)enones and arylboronic acids was tested. Almost every combination provided the product in an excellent yield (60-99\%) and enantioselectivity (up to $97 \%$ ee; Table 4 ), the only exception being the addition of an ortho-substituted boronic acid (entry 5, Table 4) [36].

In 2008, the same group further expanded the substrate scope of the addition reaction to electron-rich chalcones. The products obtained after the addition reaction with arylboronic acids were further subjected to a regioselective Bayer-Villiger oxidation (Table 5) [3].
An enhanced protocol for the synthesis of 4-aryldihydrocoumarins (Table 6) was also presented [3], which was already mentioned above (Scheme 1) [34].

Both presented methods were used in the synthesis of an antimuscarinic drug $(R)$-tolterodine (Scheme 2) [3].

A plausible catalytic cycle has been proposed (Scheme 3). The usual cross-coupling of an organoboron to $\mathrm{Pd}(0)$ requires a base. In the case of $\mathrm{Pd}(\mathrm{II})$ this reaction smoothly progresses under neutral conditions. The authors postulated that the vacancy on the square-planar Pd(II) species allows a faster alkene insertion in comparison to $\operatorname{Pd}(0)$. The cationic $\operatorname{Pd}(\mathrm{II})$ 
Table 4: Synthesis of enantiomerically enriched 1 -aryl-1H-indenes [36].
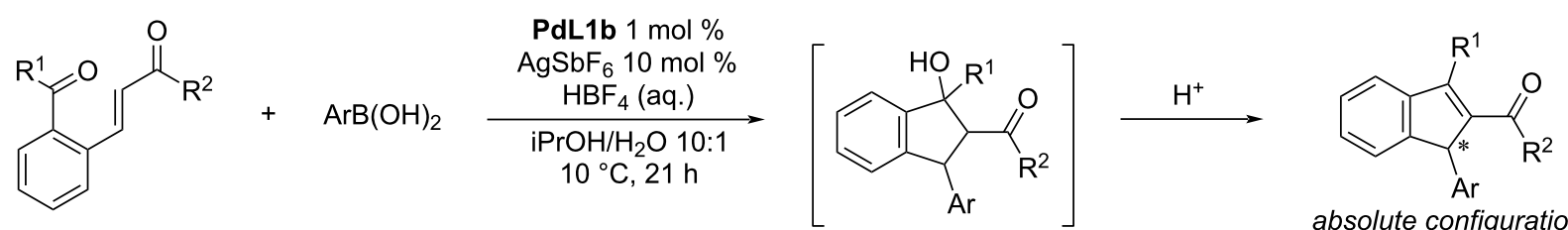

absolute configuration not given

\begin{tabular}{|c|c|c|c|c|c|}
\hline entry & $\mathrm{R}^{1}$ & $\mathrm{R}^{2}$ & $\mathrm{Ar}$ & yield (\%) & ee $(\%)$ \\
\hline 1 & $\mathrm{Me}$ & $\mathrm{Me}$ & $\mathrm{Ph}$ & 95 & 90 \\
\hline 2 & $\mathrm{Me}$ & $\mathrm{Me}$ & $4-\mathrm{Cl}-\mathrm{C}_{6} \mathrm{H}_{4}$ & 91 & 90 \\
\hline 3 & $\mathrm{Me}$ & $\mathrm{Me}$ & $3-\mathrm{Cl}-\mathrm{C}_{6} \mathrm{H}_{4}$ & 88 & 91 \\
\hline 4 & $\mathrm{Me}$ & $\mathrm{Me}$ & 4-Me- $\mathrm{C}_{6} \mathrm{H}_{4}$ & 94 & 93 \\
\hline 5 & $\mathrm{Me}$ & $\mathrm{Me}$ & $2-\mathrm{MeO}-\mathrm{C}_{6} \mathrm{H}_{4}$ & 60 & 24 \\
\hline 6 & $\mathrm{Me}$ & $\mathrm{Me}$ & 3- $\mathrm{MeO}-\mathrm{C}_{6} \mathrm{H}_{4}$ & 91 & 93 \\
\hline 7 & $\mathrm{Me}$ & $\mathrm{Me}$ & 4- $\mathrm{MeO}-\mathrm{C}_{6} \mathrm{H}_{4}$ & 90 & 96 \\
\hline 8 & $\mathrm{Me}$ & $\mathrm{Me}$ & $3,4-\left(\mathrm{CH}_{2} \mathrm{O}_{2}\right)-\mathrm{C}_{6} \mathrm{H}_{3}$ & 76 & 93 \\
\hline 9 & $\mathrm{Me}$ & $\mathrm{Me}$ & 4-(4-MeO- $\left.\mathrm{C}_{6} \mathrm{H}_{4}\right)-\mathrm{C}_{6} \mathrm{H}_{4}$ & 91 & 97 \\
\hline 10 & $\mathrm{Me}$ & $\mathrm{Me}$ & $3-\mathrm{BnO}-\mathrm{C}_{6} \mathrm{H}_{4}$ & 90 & 94 \\
\hline 11 & $\mathrm{Ph}$ & $\mathrm{Me}$ & 4- $\mathrm{MeO}-\mathrm{C}_{6} \mathrm{H}_{4}$ & 99 & 92 \\
\hline 12 & $\mathrm{Ph}$ & $4-\mathrm{MeO}-\mathrm{C}_{6} \mathrm{H}_{4}$ & 4- $\mathrm{MeO}-\mathrm{C}_{6} \mathrm{H}_{4}$ & 79 & 90 \\
\hline 13 & $\mathrm{Ph}$ & 4-MeO- $\mathrm{C}_{6} \mathrm{H}_{4}$ & $3,4-\left(\mathrm{CH}_{2} \mathrm{O}_{2}\right)-\mathrm{C}_{6} \mathrm{H}_{3}$ & 81 & 90 \\
\hline 14 & $\mathrm{Me}$ & Et & 4- $\mathrm{MeO}-\mathrm{C}_{6} \mathrm{H}_{4}$ & 99 & 93 \\
\hline 15 & $\mathrm{H}$ & $\mathrm{Me}$ & $4-\mathrm{MeO}-\mathrm{C}_{6} \mathrm{H}_{4}$ & 60 & 90 \\
\hline
\end{tabular}

Table 5: Stepwise addition of arylboronic acids to electron-rich chalcones and Bayer-Villiger oxidation [3].

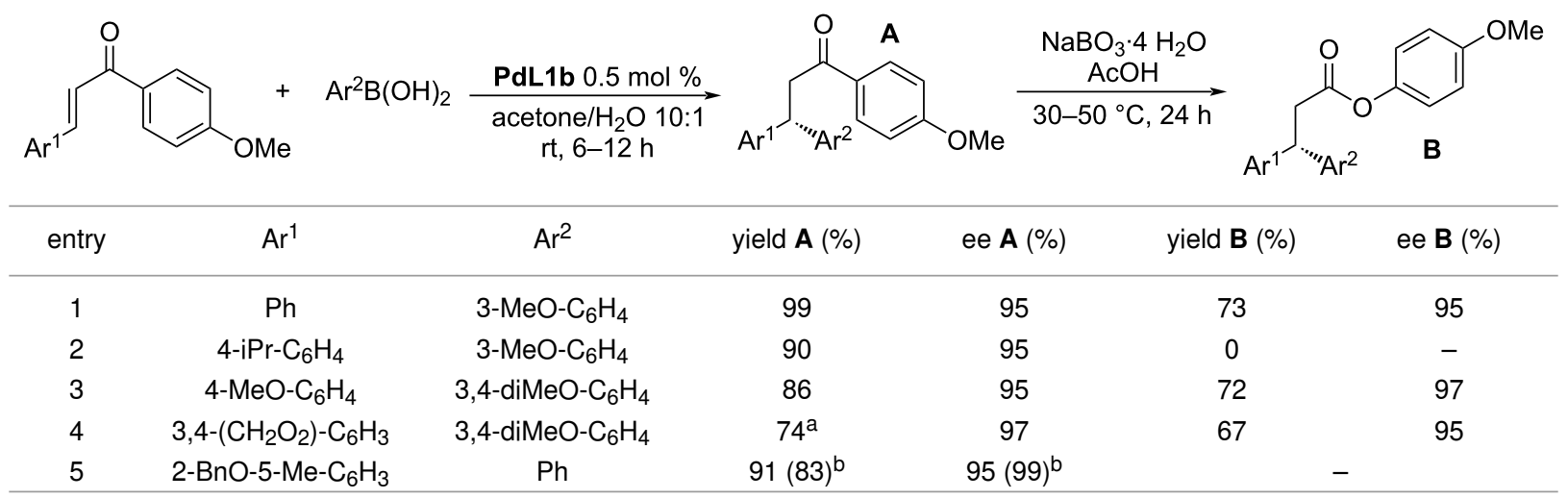

aReaction performed in $\mathrm{MeOH} /$ water 10:1 instead of acetone/water 10:1; bafter recrystallization.

enolate exists as a dynamic mixture of $C$ - and $O$-bound enolate and is highly susceptible to hydrolysis. This means that in the presence of water, it is selectively converted to the 1,4-addition product instead of undergoing a $\beta$-hydride elimination leading to an oxidative Heck product $[3,26,35]$.

In 2005, one month after the very first report of the addition of aryltrifluoroborates to enones by Miyaura [32], the Minnaard group reported a protocol for the addition of boronic acids to enones [37]. At first, they tested the combination of $\mathrm{Pd}(\mathrm{OAc})_{2}$ with triflic acid (TfOH) to obtain a $\mathrm{Pd}(\mathrm{II})$ complex with a weakly coordinating anion that is necessary for a fast $\mathrm{Pd}-\mathrm{C}$ bond cleavage and thus avoiding the undesired $\beta$-hydride elimination. However, the obtained yields were inconsistent. The usage of $\operatorname{Pd}(\mathrm{TFA})_{2}$ led to a better reproducibility of the results. From the various diphosphine ligands tested, $(R, R)-\mathrm{MeDuPhos}$ 
Table 6: Synthesis of 4-aryldihydrocoumarins by stepwise 1,4-addition and Bayer-Villiger oxidation [3].

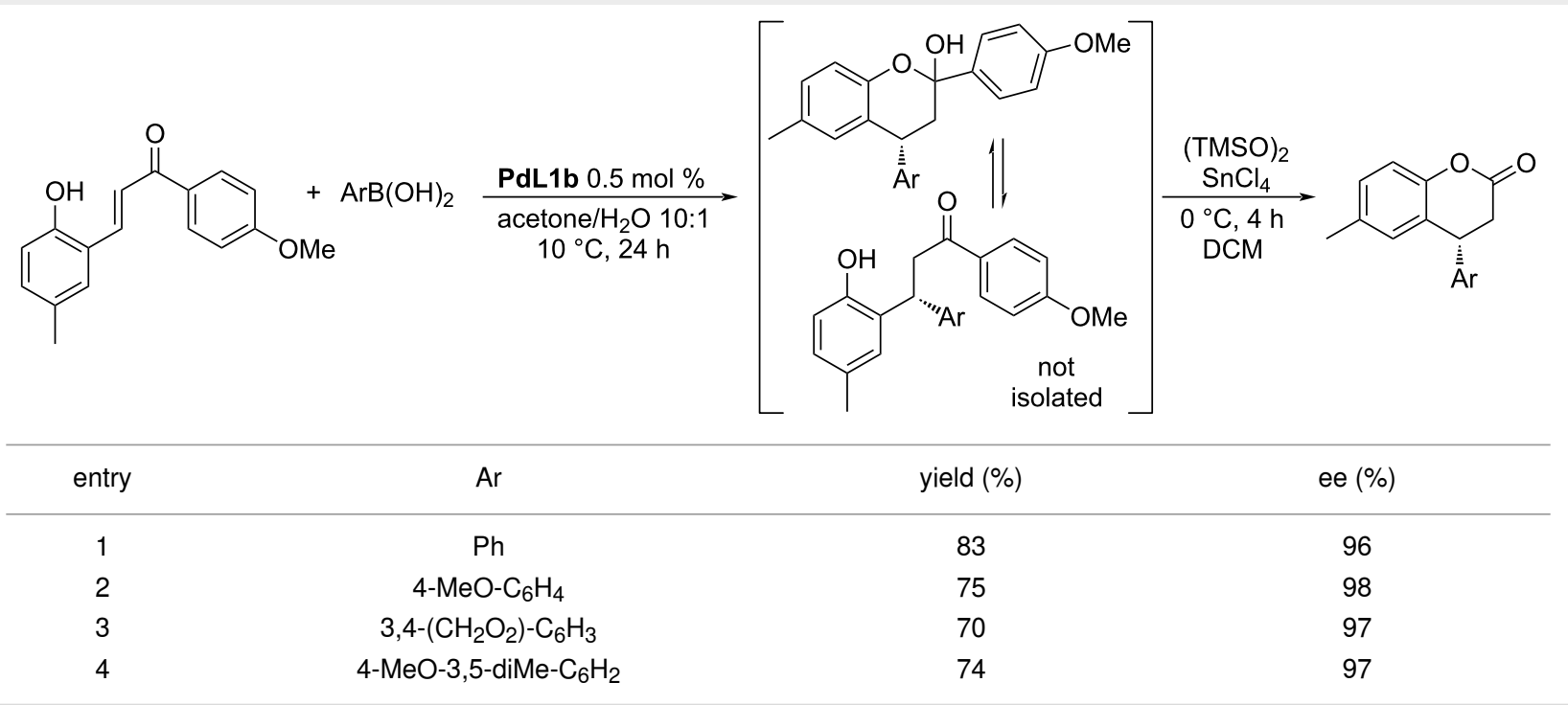<smiles>Cc1ccc2c(c1)C(Br)CC(=O)O2</smiles>

$(96 \%$ ee)

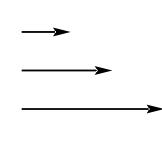

Scheme 2: Synthesis of $(R)$-tolterodine [3]<smiles>Cc1ccc(O)c([C@H](CCN(C(C)C)C(C)C)c2ccccc2)c1</smiles>

$(R)$-tolterodine

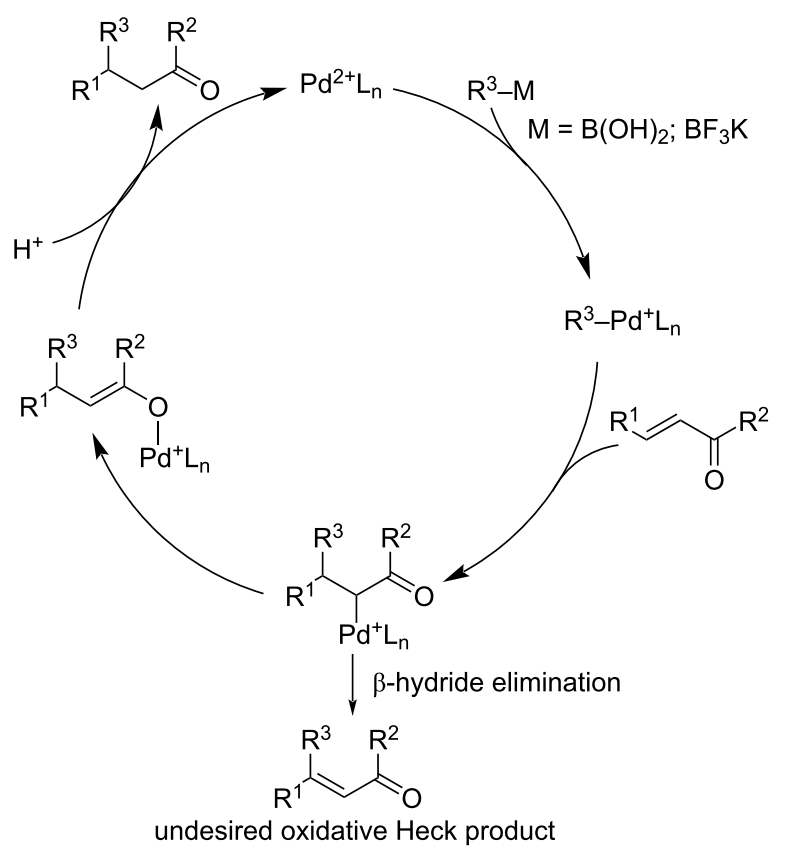

Scheme 3: Catalytic cycle of the Pd(II)-catalysed 1,4-addition of organoboron reagents to enones [3,26,35].
(L2) was identified as the one leading to the best level of enantioselectivity (up to $99 \%$ yield and up to $99 \%$ ee; Table 7) [37].

Furthermore, water was discovered to be a crucial additive in the reaction, increasing the yield without impact on the enantioselectivity [37]. The presented catalytic system worked well in the case of electron-rich arylboronic acids (entries 1-6, Table 7). Electron-poor arylboronic acids reacted much slower or did not react at all due to the slow transmetalation to Pd (entries 7 and 8, Table 7) [37]. The addition of phenylboronic acid (or aprotic triphenylboroxine with slow addition of water to the reaction mixture) was also tested in combination with enones differing in ring size, unsaturated lactone, $\mathrm{N}$-protected dihydropyridone and one example of a linear substrate. In all cases a decreased reactivity was observed, however, good to excellent enantioselectivity levels were maintained (81-99\% ee; Table 8) [37].

To our best knowledge, at this time only one method for the enantioselective $\beta$-arylation of cyclic ketones is known [38]. In 2017, Hu et al. presented the possibility of an enantioselective $\beta$-arylation of cyclohexanone using the above mentioned ligand L2. Cyclohexanone was in situ oxidized by 2-iodoxybenzoic 
Table 7: First report of the Pd-catalysed enantioselective addition of boronic acids to cyclic enones [37].
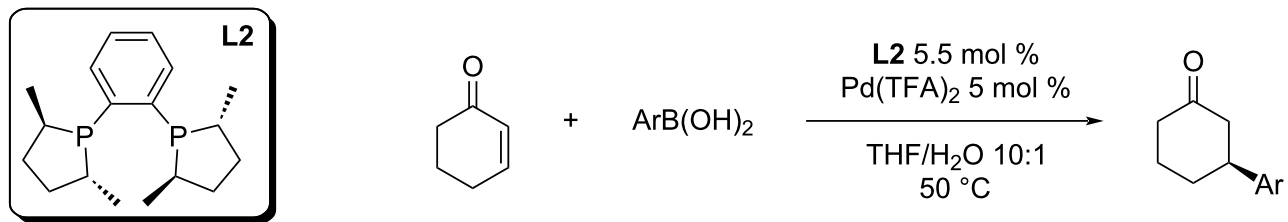

\begin{tabular}{|c|c|c|c|c|}
\hline entry & $\mathrm{Ar}$ & time $(\mathrm{h})$ & yield (\%) & ee $(\%)$ \\
\hline 1 & $\mathrm{Ph}$ & 6 & 80 & 98 \\
\hline 2 & 2-MeO- $\mathrm{C}_{6} \mathrm{H}_{4}$ & 18 & 80 & 99 \\
\hline 3 & $2-\mathrm{Me}-\mathrm{C}_{6} \mathrm{H}_{4}$ & 18 & $>99$ & 99 \\
\hline 4 & $3-\mathrm{Me}-\mathrm{C}_{6} \mathrm{H}_{4}$ & 18 & $>99$ & 97 \\
\hline 5 & 3-MeO- $\mathrm{C}_{6} \mathrm{H}_{4}$ & 18 & 98 & 97 \\
\hline 6 & 4-Me- $\mathrm{C}_{6} \mathrm{H}_{4}$ & 18 & 90 & 98 \\
\hline 7 & $3-\mathrm{NO}_{2}-\mathrm{C}_{6} \mathrm{H}_{4}$ & 24 & 0 & - \\
\hline 8 & $3-\mathrm{Cl}-\mathrm{C}_{6} \mathrm{H}_{4}$ & 24 & 40 & 98 \\
\hline
\end{tabular}

Table 8: Addition of boron-derived $C$-nucleophiles to cyclic enones, catalysed by $\operatorname{L2/Pd(TFA)} 2$ [37].

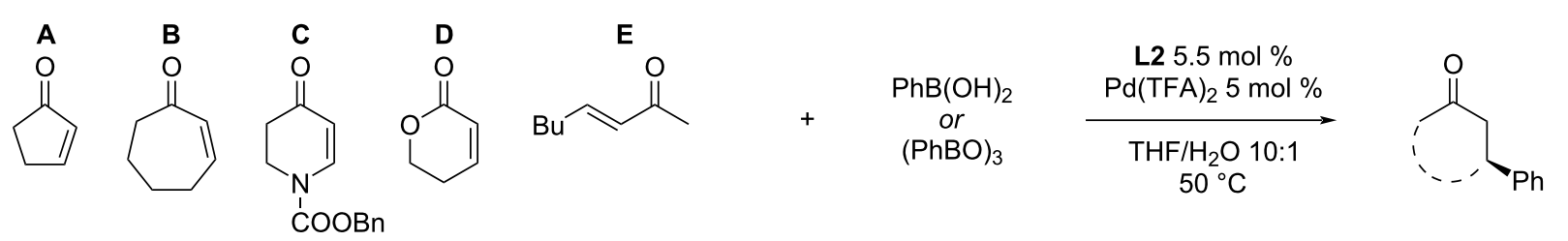

\begin{tabular}{|c|c|c|c|c|c|}
\hline entry & substrate & $C$-nucleophile & time $(\mathrm{h})$ & yield (\%) & ee $(\%)$ \\
\hline 1 & A & $\mathrm{PhB}(\mathrm{OH})_{2}$ & 6 & 75 & 82 \\
\hline 2 & B & $\mathrm{PhB}(\mathrm{OH})_{2}$ & 18 & 55 & 86 \\
\hline 3 & C & $\mathrm{PhB}(\mathrm{OH})_{2}$ & 22 & 60 & $>99$ \\
\hline 4 & D & $\begin{array}{c}(\mathrm{PhBO})_{3} \\
\text { (slow addition of water) }\end{array}$ & 5 & 75 & 94 \\
\hline 5 & $\mathbf{E}$ & $\begin{array}{c}(\mathrm{PhBO})_{3} \\
\text { (slow addition of water) }\end{array}$ & 18 & $45(60 \% a)$ & 81 \\
\hline
\end{tabular}

aConversion

acid (IBX) to 2-cyclohexenone, that subsequently underwent addition of phenylboronic acid (Scheme 4). The complex $\mathbf{L 2} / \mathrm{Pd}(\mathrm{OAc})_{2}$ was used to obtain the product with excellent enantioselectivity (95\% ee) but only poor yield (12\%) (Scheme 4$)$ [38].

A catalytic system based on $\mathbf{L} 2 / \mathrm{Pd}(\mathrm{OAc})_{2}$ was recently used by Khatua et al. for the synthesis of ar-macrocarpenes with excellent yields and enantioselectivities (89-92\%; 91-99\% ee; Scheme 5) [8].

In 2007, the group of Ito described the application of ferrocenylphosphines for the palladium-catalysed addition of aryl-

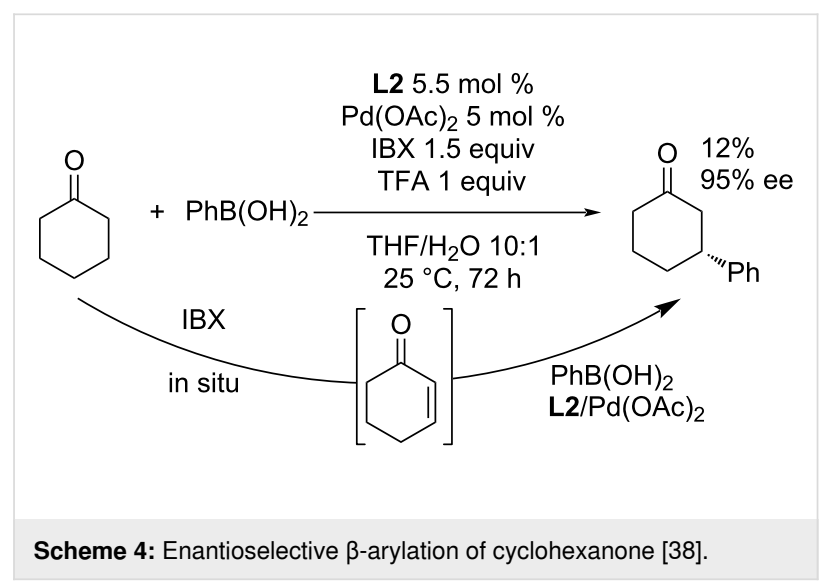




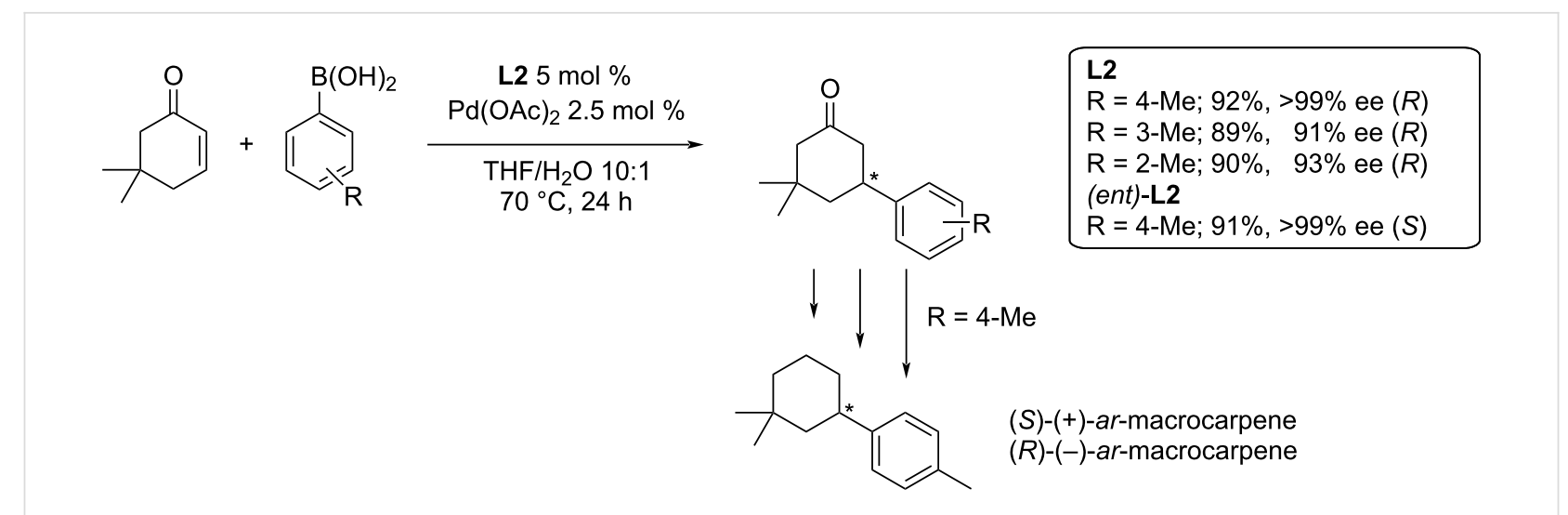

Scheme 5: Application of $\mathbf{L 2} / \mathrm{Pd}(\mathrm{OAc})_{2}$ in the total synthesis of terpenes [8].

boronic acids to 2-cyclohexenone at various temperatures giving the products with high conversions but only very low enantioselectivities (25-71\% ee; Table 9) [39].

The same group continued their work on this catalytic system under different reaction conditions with the cheaper base $\mathrm{K}_{2} \mathrm{CO}_{3}$ and without the addition of water. The observed yields were excellent (45-94\%) although the enantioselectivities were only average to poor (4-79\% ee; entries $1-9$, Table 10). Also several linear enones were tested giving the products with varying yields (53-99\%) and only moderate enantioselectivities (42-52\% ee; entries 10-13, Table 10) [40]. Additionally, the authors proposed a plausible catalytic cycle for the reaction (Scheme 6) [40].

A different approach using microwave irradiation was explored by the group of Toma et al. [41]. After an initial tuning of the reaction conditions of a catalytic system based on $\mathrm{Pd}(\mathrm{OAc})_{2} /$ 2,2'-bipy several optically pure phosphoramidite and diphosphine ligands in combination with $\mathrm{Pd}_{2}(\mathrm{dba})_{3} \cdot \mathrm{CHCl}_{3}$ were tested [41]. The obtained yields were within the range of $12-37 \%$ with enantioselectivities $12-85 \%$ ee. The best level of enantioselectivity was achieved using diphosphine ligand L4 (Scheme 7). The results in terms of both yield and enantioselectivity were very poor $(37 \% ; 85 \%$ ee), but the reaction times were very short (Scheme 7) [41].

In 2011, the groups of Hayashi and Chujo studied Pd complexes of diphosphacrown ethers [42]. The macrocyclic Pd complex PdL5 in combination with $\mathrm{AgSbF}_{6}$ or AgOTf was tested for the addition reaction of various arylboronic acids to 2-cyclopentenone. In the case of the addition of phenylboronic acid, high yields and enantioselectivities were achieved (83-92\% ee; entries 1-4, Table 11). However, in the case of

Table 9: Asymmetric addition of arylboronic acids to 2-cyclohexenone catalysed by $\mathbf{L} 3 / \mathrm{Pd}(\mathrm{dba})_{2}$ [39].
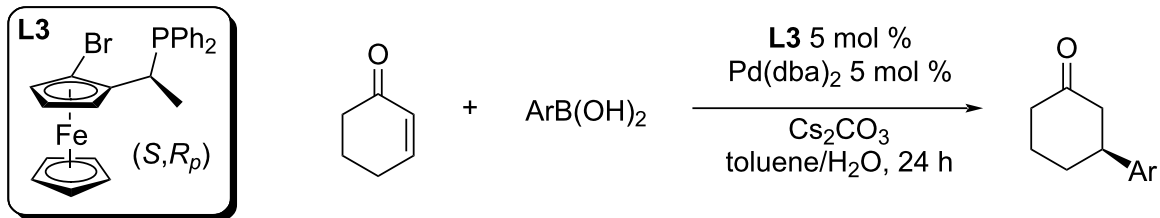

\begin{tabular}{ccccc}
\hline entry & $\mathrm{Ar}$ & temp. $\left({ }^{\circ} \mathrm{C}\right)$ & yield (\%) & \\
\hline 1 & $\mathrm{Ph}$ & 80 & 82 & 42 \\
2 & $\mathrm{Ph}$ & 60 & 83 & 79 \\
3 & $\mathrm{Ph}$ & 25 & 86 & 61 \\
4 & $4-\mathrm{Me}-\mathrm{C}_{6} \mathrm{H}_{4}$ & 80 & 90 & 71 \\
5 & $4-\mathrm{Me}-\mathrm{C}_{6} \mathrm{H}_{4}$ & 25 & 93 & 25 \\
7 & $2-\mathrm{Me}-\mathrm{C}_{6} \mathrm{H}_{4}$ & 80 & 63 & 58
\end{tabular}


Table 10: Additions to different enones catalysed by $\mathrm{L} 3 / \mathrm{Pd}(\mathrm{dba})_{2}[40]$.

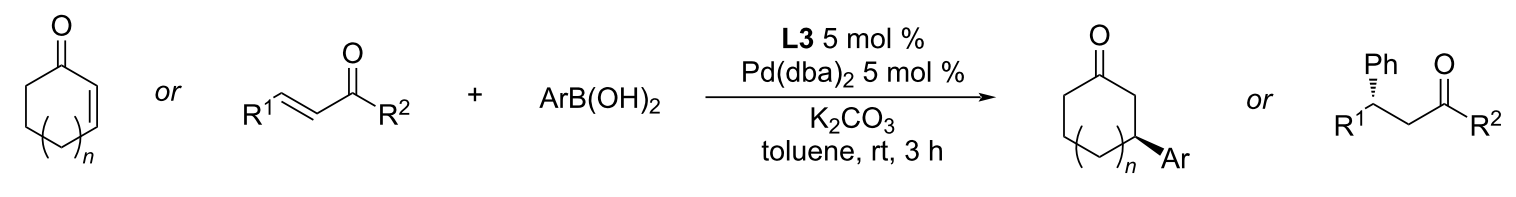

\begin{tabular}{|c|c|c|c|c|}
\hline entry & $\begin{array}{c}\text { cyclic substrates } \\
n\end{array}$ & $\mathrm{Ar}$ & yield (\%) & ee $(\%)$ \\
\hline 1 & 0 & $\mathrm{Ph}$ & 94 & 54 \\
\hline 2 & 1 & $\mathrm{Ph}$ & 92 & 76 \\
\hline 3 & 1 & $4-\mathrm{Me}-\mathrm{C}_{6} \mathrm{H}_{4}$ & 89 & 78 \\
\hline 4 & 1 & $4-\mathrm{MeO}-\mathrm{C}_{6} \mathrm{H}_{4}$ & 83 & 76 \\
\hline 5 & 1 & $4-t-\mathrm{Bu}-\mathrm{C}_{6} \mathrm{H}_{4}$ & 92 & 79 \\
\hline 6 & 1 & $4-\mathrm{CF}_{3}-\mathrm{C}_{6} \mathrm{H}_{4}$ & 81 & 4 \\
\hline 7 & 1 & $4-\mathrm{F}-\mathrm{C}_{6} \mathrm{H}_{4}$ & 45 & 68 \\
\hline 8 & 1 & 1-naphthyl & 80 & 42 \\
\hline 9 & 2 & $\mathrm{Ph}$ & 90 & 38 \\
\hline
\end{tabular}

\begin{tabular}{ccccc}
\hline \multicolumn{2}{c}{ acyclic substrates } & & & \\
& $\mathrm{R}^{1}$ & $\mathrm{R}^{2}$ & & \\
\hline 10 & $\mathrm{Me}$ & $\mathrm{Me}$ & $\mathrm{Ph}$ & 53 \\
11 & $\mathrm{Me}$ & $\mathrm{Et}$ & $\mathrm{Ph}$ & 62 \\
12 & $\mathrm{iPr}$ & $\mathrm{Me}$ & $\mathrm{Ph}$ & 70 \\
13 & $n-\mathrm{C}_{5} \mathrm{H}_{11}$ & $\mathrm{Me}$ & $\mathrm{Ph}$ & 94 \\
\hline
\end{tabular}

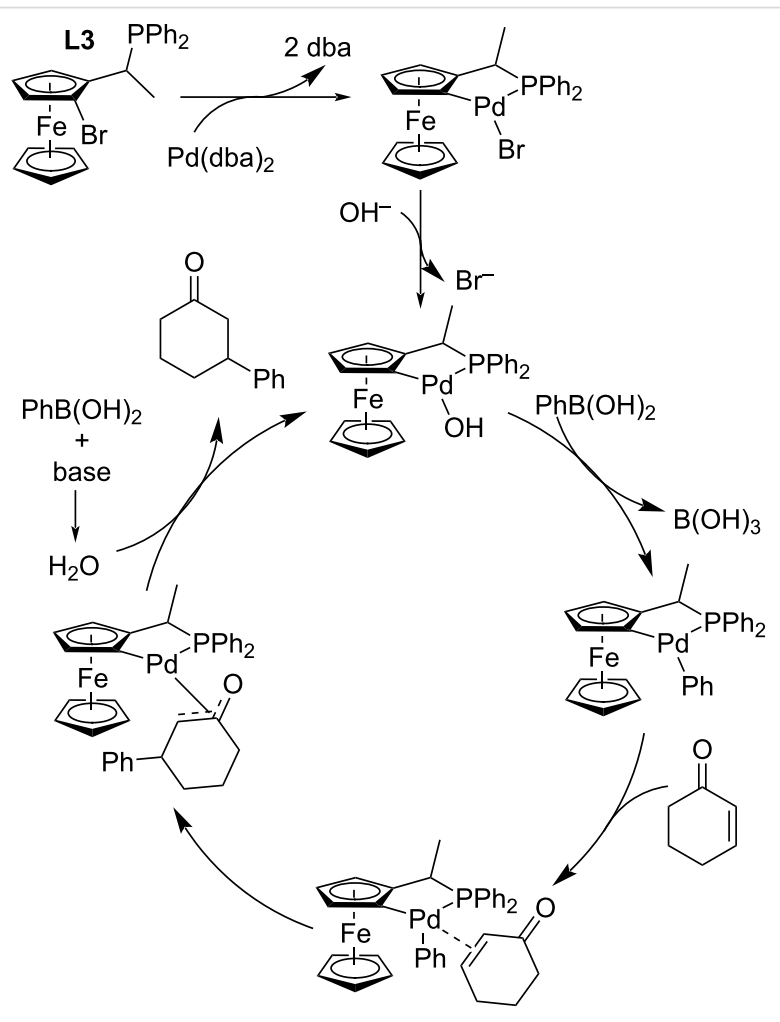

Scheme 6: Plausible catalytic cycle for the addition of phenylboronic acid to 2-cyclohexenone catalysed by $\mathbf{L} 3 / \mathrm{Pd}(\mathrm{dba})_{2}[40]$.
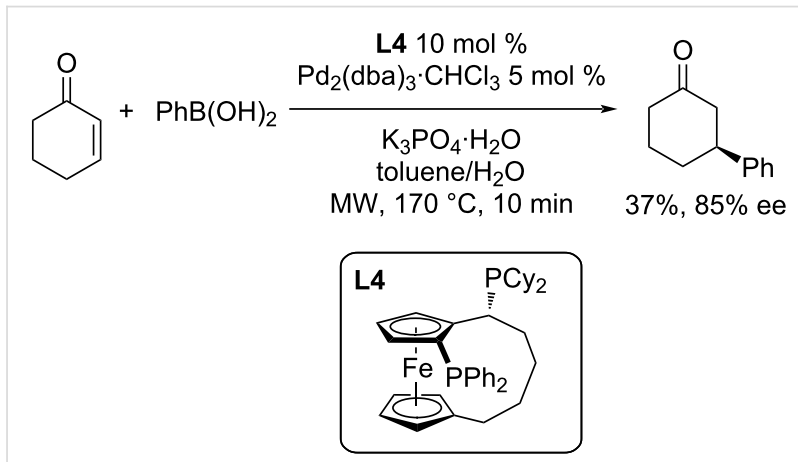

Scheme 7: Microwave-assisted addition of phenylboronic acid to 2-cyclohexenone catalysed by $\mathrm{L} 4 / \mathrm{Pd}_{2}(\mathrm{dba})_{3} \cdot \mathrm{CHCl}_{3}[41]$.

substituted boronic acids decreased enantioselectivities were observed (72-82\% ee; entries 5-8, Table 11) [42].

The most recent systematic study of phosphine-based Pd complexes was done by Wong et al. in 2014. The palladacycle PdL6 was used in combination with triphenylphosphine and $\mathrm{K}_{3} \mathrm{PO}_{4}$ acting as a base. The highest enantioselectivity of $99 \%$ ee of a model addition of phenylboronic acid to 2-cyclohexenone was achieved in dioxane as the solvent, but the yield was only $22 \%$. Therefore, the authors used toluene as the best compromise between yield and enantioselectivity for the next 
Table 11: Addition of arylboronic acid on 2-cyclopentenone catalysed by PdL5 [42].
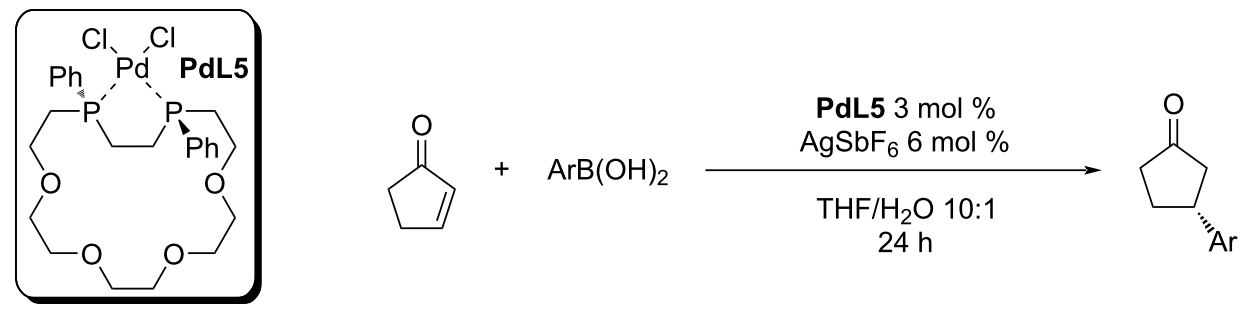

\begin{tabular}{|c|c|c|c|c|}
\hline entry & $\mathrm{Ar}$ & temp. $\left({ }^{\circ} \mathrm{C}\right)$ & yield (\%) & ee $(\%)$ \\
\hline 1 & $\mathrm{Ph}$ & 30 & 90 & 85 \\
\hline 2 & $\mathrm{Ph}$ & 0 & 89 & 87 \\
\hline 3 & $\mathrm{Ph}$ & 30 & $>99^{a}$ & 83 \\
\hline 4 & $\mathrm{Ph}$ & 0 & $36^{a}$ & 92 \\
\hline 5 & $4-\mathrm{MeO}-\mathrm{C}_{6} \mathrm{H}_{4}$ & 30 & 94 & 82 \\
\hline 6 & $4-\mathrm{CF}_{3}-\mathrm{C}_{6} \mathrm{H}_{4}$ & 30 & 91 & 72 \\
\hline 7 & $4-\mathrm{Br}-\mathrm{C}_{6} \mathrm{H}_{4}$ & 30 & 95 & 78 \\
\hline 8 & $2-\mathrm{Me}-\mathrm{C}_{6} \mathrm{H}_{4}$ & 30 & 94 & 72 \\
\hline
\end{tabular}

study (Table 12). The addition reaction using the five-membered enone provided the product in moderate yield and enantioselectivity $(64 \% ; 50 \%$ ee; entry 1 , Table 12$)$. On the other hand, the addition of phenylboronic acid to six and seven-membered cycles as well as linear substrates provided the products with high yields (72-97\%) and enantioselectivities (78-92\% ee;

Table 12: Application of dimeric palladacycle PdL6 in the addition reactions of arylboronic acids to various enones [43].

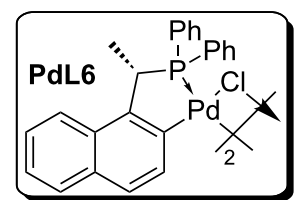

In

or $\mathrm{R}^{1} \stackrel{\mathrm{O}}{\mathrm{l}}_{\mathrm{R}^{2}}$

$+\operatorname{ArB}(\mathrm{OH})_{2}$
PdL6 $2.5 \mathrm{~mol} \%$ $\mathrm{PPh}_{3} 5 \mathrm{~mol} \%$

$\mathrm{K}_{3} \mathrm{PO}_{4}$ toluene, $25^{\circ} \mathrm{C}$<smiles></smiles>

\begin{tabular}{|c|c|c|c|c|}
\hline entry & cyclic substrates & $\mathrm{Ar}$ & yield (\%) & ee $(\%)$ \\
\hline & $n$ & & & \\
\hline 1 & 0 & $\mathrm{Ph}$ & 64 & $50(S)$ \\
\hline 2 & 1 & $\mathrm{Ph}$ & 89 & $92(R)$ \\
\hline 3 & 2 & $\mathrm{Ph}$ & 72 & $87(R)$ \\
\hline
\end{tabular}

\begin{tabular}{|c|c|c|c|c|c|}
\hline \multicolumn{3}{|c|}{ acyclic substrates } & & & \\
\hline & $\mathrm{R}^{1}$ & $\mathrm{R}^{2}$ & & & \\
\hline 4 & $4-\mathrm{F}-\mathrm{C}_{6} \mathrm{H}_{4}$ & $\mathrm{Ph}$ & $\mathrm{Ph}$ & 88 & 81 \\
\hline 5 & $4-\mathrm{Cl}-\mathrm{C}_{6} \mathrm{H}_{4}$ & $\mathrm{Ph}$ & $\mathrm{Ph}$ & 92 & 78 \\
\hline 6 & 4-Br- $\mathrm{C}_{6} \mathrm{H}_{4}$ & $\mathrm{Ph}$ & $\mathrm{Ph}$ & 88 & 78 \\
\hline 7 & $4-\mathrm{MeO}-\mathrm{C}_{6} \mathrm{H}_{4}$ & $\mathrm{Ph}$ & $\mathrm{Ph}$ & 95 & 81 \\
\hline 8 & $4-\mathrm{Me}-\mathrm{C}_{6} \mathrm{H}_{4}$ & $\mathrm{Ph}$ & $\mathrm{Ph}$ & 97 & 81 \\
\hline 9 & $4-\mathrm{CF}_{3}-\mathrm{C}_{6} \mathrm{H}_{4}$ & $\mathrm{Ph}$ & $\mathrm{Ph}$ & 92 & 69 \\
\hline 10 & 2-naphthyl & $\mathrm{Ph}$ & $\mathrm{Ph}$ & 88 & 85 \\
\hline 11 & $4-\mathrm{Ph}-\mathrm{C}_{6} \mathrm{H}_{4}$ & $\mathrm{Ph}$ & $\mathrm{Ph}$ & 85 & 79 \\
\hline
\end{tabular}


Table 12: Application of dimeric palladacycle PdL6 in the addition reactions of arylboronic acids to various enones [43]. (continued)

\begin{tabular}{|c|c|c|c|c|c|}
\hline 12 & $3,4-\left(\mathrm{CH}_{2} \mathrm{O}_{2}\right)-\mathrm{C}_{6} \mathrm{H}_{3}$ & $\mathrm{Ph}$ & $\mathrm{Ph}$ & 95 & 81 \\
\hline 13 & $\mathrm{Ph}$ & $\mathrm{Me}$ & 4-Me- $\mathrm{C}_{6} \mathrm{H}_{4}$ & 63 & 87 \\
\hline 14 & $\mathrm{Me}$ & $\mathrm{Me}$ & $\mathrm{Ph}$ & 56 & 93 \\
\hline 15 & $\mathrm{Ph}$ & $\mathrm{Ph}$ & 2-naphthyl & 97 & 77 \\
\hline 16 & $\mathrm{Ph}$ & $\mathrm{Ph}$ & $4-\mathrm{F}-\mathrm{C}_{6} \mathrm{H}_{4}$ & 92 & 79 \\
\hline 17 & $\mathrm{Ph}$ & $\mathrm{Ph}$ & $4-\mathrm{Cl}-\mathrm{C}_{6} \mathrm{H}_{4}$ & 56 & 82 \\
\hline 18 & $\mathrm{Ph}$ & $\mathrm{Ph}$ & $4-\mathrm{Br}_{-} \mathrm{C}_{6} \mathrm{H}_{4}$ & 88 & 56 \\
\hline 19 & $\mathrm{Ph}$ & $\mathrm{Ph}$ & 4-Me- $\mathrm{C}_{6} \mathrm{H}_{4}$ & 89 & 69 \\
\hline 20 & $\mathrm{Ph}$ & $\mathrm{Ph}$ & 4- $\mathrm{MeO}-\mathrm{C}_{6} \mathrm{H}_{4}$ & 83 & 85 \\
\hline 21 & $\mathrm{Ph}$ & $\mathrm{Ph}$ & $4-\mathrm{CF}_{3}-\mathrm{C}_{6} \mathrm{H}_{4}$ & 47 & 80 \\
\hline
\end{tabular}

entries 2, 3, 4-12, Table 12). In reactions with substituted arylboronic acids and selected acyclic enones comparable enantioselectivities were observed, while the yields were slightly lower in most cases (56-93\% ee, 47-97\%; entries 13-21, Table 12) [43].

Furthermore, the authors proposed a catalytic cycle (Scheme 8) [43] and stated that the rate-determining step (RDS) was the protonolysis of the $O$-bound enolate in the presence of $\mathrm{PPh}_{3}$ that leads to the regeneration of the catalytically active hydroxopal-

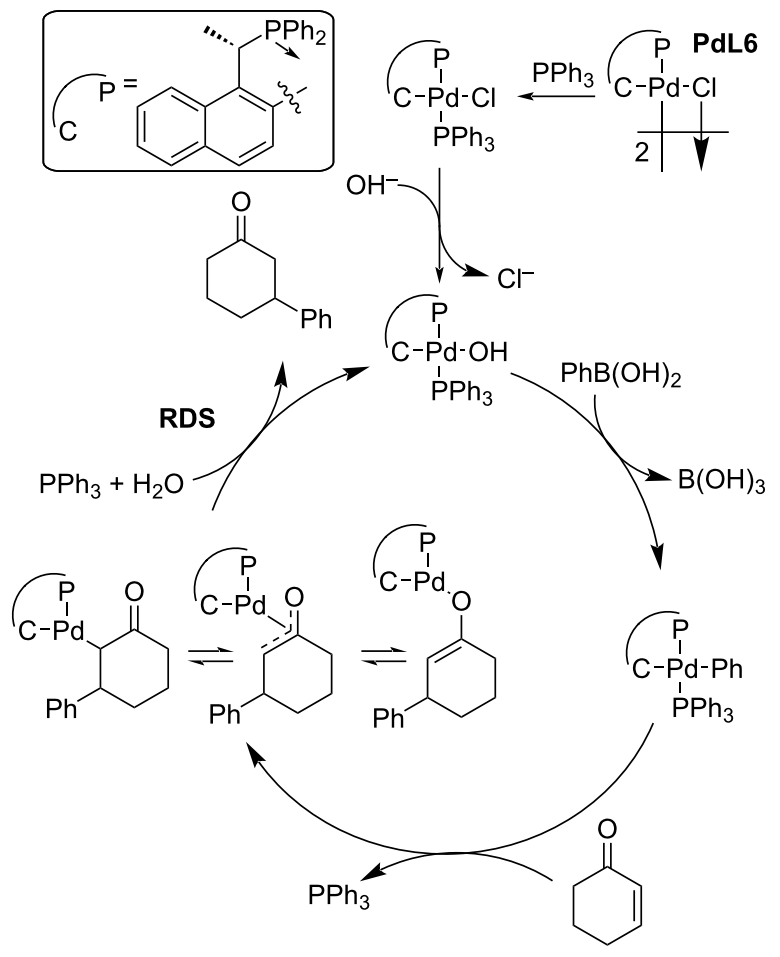

Scheme 8: Plausible catalytic cycle of the addition of phenylboronic acid to 2-cyclohexenone catalysed by palladacycle PdL6 [43]. ladium species and the addition product (Scheme 8) [43]. The presence of $\mathrm{PPh}_{3}$ ensures the preference of hydrolysis instead of a $\beta$-hydride elimination, which would lead to an oxidative Heck-type product. The authors stated that as a result of the coordination with $\mathrm{PPh}_{3}$, there is a steric hindrance disfavouring the $\beta$-hydride elimination [43].

\section{Catalytic systems based on NHC ligands}

Historically, the second type of ligands used were $N$-heterocyclic carbenes (NHC). The first use was reported in a work Shi and co-workers in 2008 who studied the addition of arylboronic acids to 2-cyclohexenone catalysed by Pd complexes of axially chiral NHC carbenes with two other weakly coordinating ligands [44,45]. The complexes with acetates (PdL7a), trifluoroacetates (PdL7b), and diaquo complex (PdL7c) provided similar results in the reactions with simple enones (Table 13). The authors discussed the need for the presence of $\mathrm{KOH}$ as a base $[44,45]$. Without the base the reaction did not give any product.

The broadening of the reaction scope showed that the catalysts were also suitable for reactions with seven-membered cyclic enones. However, the effectiveness was decreased in the case of five-membered rings or heterocyclic six-membered rings as the substrates (Table 14) [44].

The unsatisfactory result obtained for substrate B (entry 10, Table 14) was overcome in the next work that focused on the optimisation of the reaction conditions for the addition of arylboronic acids to substituted dihydropyridones. Under the optimised conditions, 1,4-dioxane was used instead of THF as a solvent. The obtained results for the additions of various boronic acids to a series of alkyl 4-oxo-3,4-dihydropyridine-1(2H)carboxylates were excellent in terms of both conversion (72-96\%) and enantioselectivities (87-99\% ee; Table 15) [45]. In addition, the authors proposed a catalytic cycle for this reaction (Scheme 9). 
Table 13: Addition reaction of boronic acids to 2-cyclohexenone, catalysed by Pd-NHC complexes PdL7a-c [44,45].
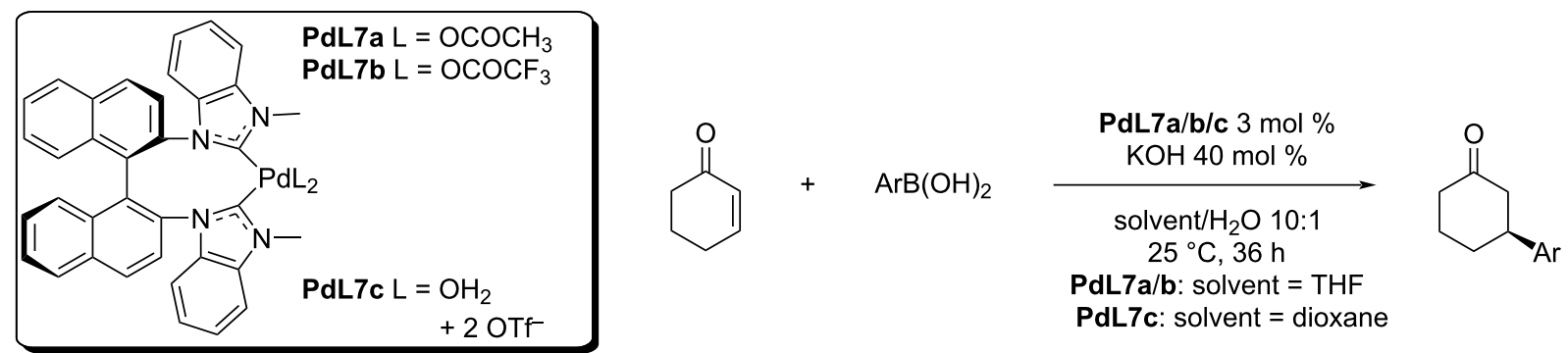

$\mathrm{PdL7a/b}:$ solvent $=\mathrm{THF}$

PdL7c: solvent = dioxane

\begin{tabular}{|c|c|c|c|c|}
\hline entry & $\operatorname{Ar}$ & catalyst & yield (\%) & ee $(\%)$ \\
\hline 1 & $\mathrm{Ph}$ & PdL7a & 95 & 93 \\
\hline 2 & $\mathrm{Ph}$ & PdL7b & 97 & 96 \\
\hline 3 & $\mathrm{Ph}$ & PdL7c & 98 & 95 \\
\hline 4 & $3-\mathrm{Me}-\mathrm{C}_{6} \mathrm{H}_{4}$ & PdL7b & 97 & 97 \\
\hline 5 & 3-Me- $\mathrm{C}_{6} \mathrm{H}_{4}$ & PdL7c & 95 & 92 \\
\hline 6 & 4-Me- $\mathrm{C}_{6} \mathrm{H}_{4}$ & PdL7b & 89 & 92 \\
\hline 7 & $4-\mathrm{Me}-\mathrm{C}_{6} \mathrm{H}_{4}$ & PdL7c & 83 & 90 \\
\hline 8 & $3-\mathrm{MeO}-\mathrm{C}_{6} \mathrm{H}_{4}$ & PdL7a & 92 & 94 \\
\hline 9 & $3-\mathrm{MeO}-\mathrm{C}_{6} \mathrm{H}_{4}$ & PdL7b & 90 & 97 \\
\hline 10 & $3-\mathrm{MeO}-\mathrm{C}_{6} \mathrm{H}_{4}$ & PdL7c & 90 & 97 \\
\hline 11 & $4-\mathrm{MeO}-\mathrm{C}_{6} \mathrm{H}_{4}$ & PdL7b & 82 & 84 \\
\hline 12 & 2-naphtyl & PdL7a & 98 & 96 \\
\hline 13 & 2-naphtyl & PdL7b & 99 & 97 \\
\hline 14 & 2-naphtyl & PdL7c & 99 & 96 \\
\hline 15 & 4- $\mathrm{Ph}-\mathrm{C}_{6} \mathrm{H}_{4}$ & PdL7b & 97 & 93 \\
\hline 16 & $3-\mathrm{Cl}-\mathrm{C}_{6} \mathrm{H}_{4}$ & PdL7b & 78 & 88 \\
\hline 17 & $3-\mathrm{Cl}-\mathrm{C}_{6} \mathrm{H}_{4}$ & PdL7c & 78 & 86 \\
\hline 18 & 3,5-diMe- $\mathrm{C}_{6} \mathrm{H}_{3}$ & PdL7b & 90 & 92 \\
\hline 19 & 3,5-diMe- $\mathrm{C}_{6} \mathrm{H}_{3}$ & PdL7c & 95 & 88 \\
\hline
\end{tabular}

Table 14: Addition reaction of arylboronic acids to different enones catalysed by Pd-NHC complexes PdL7a-c $[44,45]$.

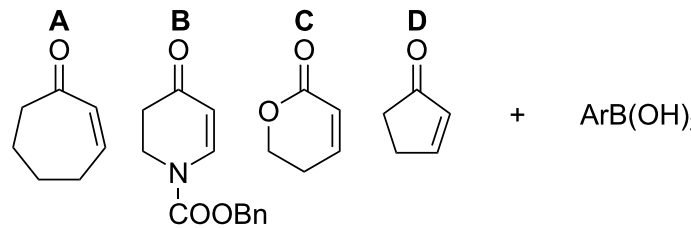

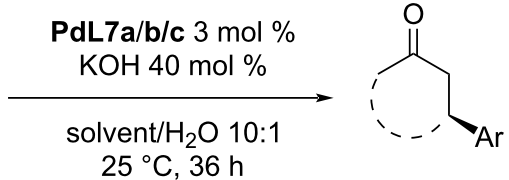

$\mathbf{P d L 7 a} / \mathbf{b}$ : solvent $=\mathrm{THF}$

PdL7c: solvent = dioxane

\begin{tabular}{|c|c|c|c|c|c|}
\hline entry & substrate & $\mathrm{Ar}$ & catalyst & yield (\%) & ee $(\%)$ \\
\hline 1 & A & $\mathrm{Ph}$ & PdL7a & 85 & 94 \\
\hline 2 & A & $\mathrm{Ph}$ & PdL7b & 88 & 91 \\
\hline 3 & A & $\mathrm{Ph}$ & PdL7c & 85 & 94 \\
\hline 4 & A & 4-Me- $\mathrm{C}_{6} \mathrm{H}_{4}$ & PdL7b & 90 & 91 \\
\hline 5 & A & 3- $\mathrm{MeO}-\mathrm{C}_{6} \mathrm{H}_{4}$ & PdL7b & 86 & 96 \\
\hline 6 & A & 3-MeO- $\mathrm{C}_{6} \mathrm{H}_{4}$ & PdL7c & 84 & 96 \\
\hline 7 & $\mathbf{A}$ & 2-naphthyl & PdL7a & 84 & 96 \\
\hline
\end{tabular}


Table 14: Addition reaction of arylboronic acids to different enones catalysed by Pd-NHC complexes PdL7a-c [44,45]. (continued)

\begin{tabular}{cccccc}
8 & A & 2-naphthyl & PdL7b & 99 & 97 \\
9 & A & 2-naphthyl & PdL7c & 93 & 94 \\
10 & B & Ph & PdL7b & $53^{\mathrm{a}}$ & 81 \\
11 & C & $\mathrm{Ph}$ & PdL7b & $62^{\mathrm{a}}$ & 38 \\
12 & D & $\mathrm{Ph}$ & PdL7b & 58 & 32 \\
\hline
\end{tabular}

areaction temperature $50^{\circ} \mathrm{C}$.

Table 15: Addition reaction of arylboronic acids to various 4-oxo-3,4-dihydropyridine-1(2H)-carboxylates catalysed by Pd-NHC complexes PdL7a-c [45].

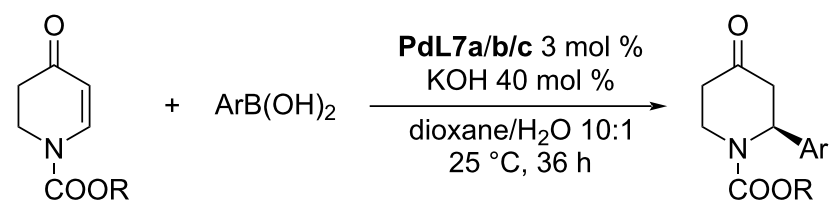

\begin{tabular}{|c|c|c|c|c|c|}
\hline entry & $\mathrm{R}$ & $\mathrm{Ar}$ & catalyst & yield (\%) & ee $(\%)$ \\
\hline 1 & $\mathrm{Bn}$ & $\mathrm{Ph}$ & PdL7a & 86 & 99 \\
\hline 2 & $\mathrm{Bn}$ & $\mathrm{Ph}$ & PdL7b & 88 & $>99$ \\
\hline 3 & $\mathrm{Bn}$ & $\mathrm{Ph}$ & PdL7c & 88 & $>99$ \\
\hline 4 & $\mathrm{Bn}$ & $4-\mathrm{Me}-\mathrm{C}_{6} \mathrm{H}_{4}$ & PdL7b & 85 & 96 \\
\hline 5 & $\mathrm{Bn}$ & 4-Me- $\mathrm{C}_{6} \mathrm{H}_{4}$ & PdL7c & 82 & 95 \\
\hline 6 & $\mathrm{Bn}$ & 3-Me- $\mathrm{C}_{6} \mathrm{H}_{4}$ & PdL7b & 80 & 95 \\
\hline 7 & $\mathrm{Bn}$ & $3-\mathrm{Me}-\mathrm{C}_{6} \mathrm{H}_{4}$ & PdL7c & 80 & 98 \\
\hline 8 & $\mathrm{Bn}$ & $4-\mathrm{MeO}-\mathrm{C}_{6} \mathrm{H}_{4}$ & PdL7b & 78 & $>99$ \\
\hline 9 & $\mathrm{Bn}$ & $4-\mathrm{MeO}-\mathrm{C}_{6} \mathrm{H}_{4}$ & PdL7c & 82 & $>99$ \\
\hline 10 & $\mathrm{Bn}$ & $3-\mathrm{MeO}-\mathrm{C}_{6} \mathrm{H}_{4}$ & PdL7b & 76 & 99 \\
\hline 11 & $\mathrm{Bn}$ & $3-\mathrm{MeO}-\mathrm{C}_{6} \mathrm{H}_{4}$ & PdL7c & 72 & 90 \\
\hline 12 & $\mathrm{Bn}$ & 2-naphthyl & PdL7b & 85 & 98 \\
\hline 13 & $\mathrm{Bn}$ & 2-naphthyl & PdL7c & 86 & 97 \\
\hline 14 & $\mathrm{Bn}$ & 4- $\mathrm{Ph}-\mathrm{C}_{6} \mathrm{H}_{4}$ & PdL7b & 94 & 97 \\
\hline 15 & $\mathrm{Bn}$ & $4-\mathrm{Ph}-\mathrm{C}_{6} \mathrm{H}_{4}$ & PdL7c & 96 & 98 \\
\hline 16 & $\mathrm{Et}$ & $\mathrm{Ph}$ & PdL7b & 92 & 87 \\
\hline 17 & Et & $\mathrm{Ph}$ & PdL7c & 90 & 98 \\
\hline 18 & $\mathrm{Et}$ & 2-naphthyl & PdL7b & 85 & 97 \\
\hline 19 & Et & 4-Ph- $\mathrm{C}_{6} \mathrm{H}_{4}$ & PdL7b & 95 & 97 \\
\hline 20 & $t-\mathrm{Bu}$ & $\mathrm{Ph}$ & PdL7b & 82 & 99 \\
\hline 21 & $t-\mathrm{Bu}$ & $\mathrm{Ph}$ & PdL7c & 80 & 98 \\
\hline 22 & $t-\mathrm{Bu}$ & 2-naphthyl & PdL7b & 80 & 97 \\
\hline 23 & $t-\mathrm{Bu}$ & 4- $\mathrm{Ph}-\mathrm{C}_{6} \mathrm{H}_{4}$ & PdL7b & 95 & $>99$ \\
\hline
\end{tabular}

In 2013, the most recent NHC-Pd based system has been developed by Mullick et al. who used ligands derived from trans9,10-dihydro-9,10-ethanoanthracene-11,12-diyl (DEA) and trans-9,10-dihydro-9,10-ethanoanthracene-11,12-diylmethanediyl (DEAM) in form of Pd-bisNHC complexes [46]. The catalysts were prepared in situ and tested for the addition reaction of various boronic acids to five and six-membered enones (Table 16). The results were unsatisfactory in terms of yield and enantioselectivity $(24-98 \% ; 30-51 \%$ ee) and most of the studied combinations gave no product or the authors were not able to determine the enantioselectivity. A selection of some interesting results is summarised in Table 16 [46]. 


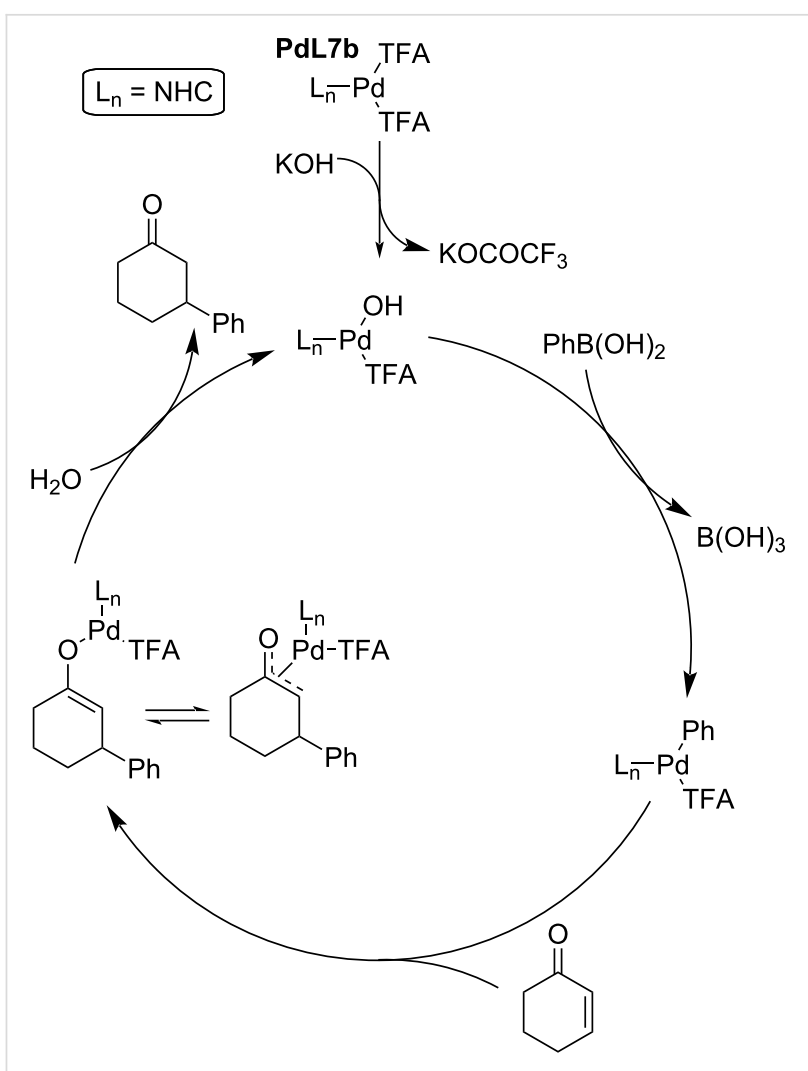

Scheme 9: Proposed catalytic cycle for the addition of phenylboronic acids to 2-cyclohexenone catalysed by Pd-NHC complex PdL7b [44].

\section{Catalytic systems based on pyridine- oxazolines ligands}

Currently, the most studied ligand class is focused on pyridineoxazolines (PyOx). The first report for the use of this type of ligand for the asymmetric addition of arylboronic acids to cyclic enones was published by the Stoltz group in 2011 [47]. The most efficient catalytic system was identified as a combination of (S)-t-Bu-PyOx (L9) with Pd(TFA) $)_{2}$ (Table 17). This system exhibited a remarkable tolerance for water and air. It was demonstrated by the addition of 10 equiv of water into the reaction mixture that caused only a very small decrease of the enantioselectivity from $93 \%$ ee to $91 \%$ ee (entries 1 and 2 , Table 17). Additional deuteration experiments demonstrated that water acted as a proton source in the catalytic cycle [48]. Furthermore, only a very low conversion was achieved without water, especially in large-scale experiments. Proton sources other than water were tested too. The use of $\mathrm{MeOH}$ or $t-\mathrm{BuOH}$ resulted in a 10 to $15 \%$ decrease of enantioselectivity and 2,2,2trifluoroethanol (TFE) had only a minimal impact on the enantioselectivity. The benefit of using TFE instead of water was its miscibility with the reaction medium (DCE) [48].

A series of different arylboronic acids was tested for the addition reaction to 3-methyl-2-cyclohexenone (Table 17). Electronpoor arylboronic acids gave generally better enantioselectivities than electron-rich arylboronic acids [47,49].

Different enone substrates varying in ring size and substitution in the 3-position were also tested. The products were usually obtained with a high degree of enantioselectivity in good yields (up to $96 \%$; up to $93 \%$ ee; Table 18 ) $[47,49]$.

An interesting finding was the effect of non-coordinating hexafluorophosphate anions. The addition of $30 \mathrm{~mol} \% \mathrm{NH}_{4} \mathrm{PF}_{6}$ increased the catalytic activity and allowed to run the reaction at a

Table 16: Addition reactions of boronic acids to five and six-membered enones catalysed by in situ-prepared Pd-bisNHC complex PdL8 [46].
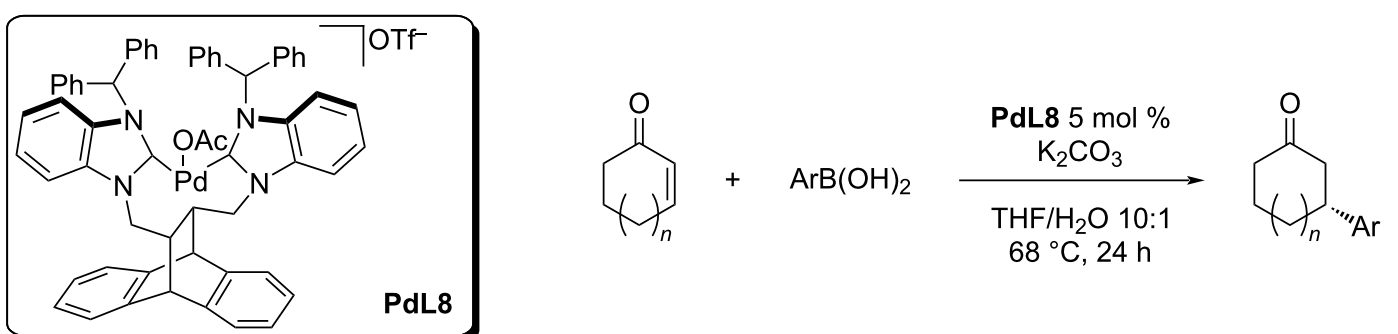

PdL8

\begin{tabular}{ccccc}
\hline entry & $n$ & Ar & yield (\%) & ee (\%) \\
\hline 1 & 0 & $2-\mathrm{Me}_{6} \mathrm{C}_{6} \mathrm{H}_{4}$ & 36 & 50 \\
2 & 0 & $2-\mathrm{MeO}-\mathrm{C}_{6} \mathrm{H}_{4}$ & 35 & 31 \\
3 & 0 & $4-\mathrm{MeO}-\mathrm{C}_{6} \mathrm{H}_{4}$ & 30 & 35 \\
4 & 0 & $1-$ naphthyl & 98 & 51 \\
6 & 1 & $\mathrm{Ph}$ & 62 & 33 \\
7 & 1 & $2-\mathrm{Me}-\mathrm{C}_{6} \mathrm{H}_{4}$ & 48
\end{tabular}


Table 17: Addition reaction of arylboronic acids to 3-methyl-2-cyclohexenone catalysed by $\operatorname{L9} / \operatorname{Pd}(\operatorname{TFA})_{2}[47,49]$.
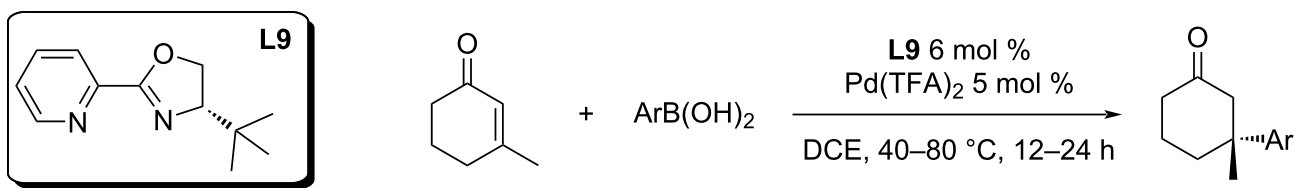

\begin{tabular}{|c|c|c|c|c|c|}
\hline entry & $\operatorname{Ar}$ & temp. $\left({ }^{\circ} \mathrm{C}\right)$ & time $(\mathrm{h})$ & yield (\%) & ee $(\%)$ \\
\hline 1 & $\mathrm{Ph}$ & 60 & 12 & 99 & 93 \\
\hline 2 & $\mathrm{Ph}$ & 60 & 12 & 99 & $91^{\mathrm{a}}$ \\
\hline 3 & 4-Me- $\mathrm{C}_{6} \mathrm{H}_{4}$ & 60 & 12 & 99 & 87 \\
\hline 4 & 4-Et- $\mathrm{C}_{6} \mathrm{H}_{4}$ & 60 & 12 & 90 & 85 \\
\hline 5 & $4-\mathrm{MeO}-\mathrm{C}_{6} \mathrm{H}_{4}$ & 40 & 24 & 58 & 69 \\
\hline 6 & $4-\mathrm{BnO}-\mathrm{C}_{6} \mathrm{H}_{4}$ & 60 & 18 & 96 & 74 \\
\hline 7 & 4-TBSO- $\mathrm{C}_{6} \mathrm{H}_{4}$ & 40 & 24 & 52 & 82 \\
\hline 8 & 4-Ac- $\mathrm{C}_{6} \mathrm{H}_{4}$ & 60 & 18 & 99 & 96 \\
\hline 9 & $4-\mathrm{Cl}-\mathrm{C}_{6} \mathrm{H}_{4}$ & 60 & 12 & 94 & 95 \\
\hline 10 & $4-\mathrm{F}-\mathrm{C}_{6} \mathrm{H}_{4}$ & 80 & 12 & 84 & 92 \\
\hline 11 & $2-\mathrm{F}-\mathrm{C}_{6} \mathrm{H}_{4}$ & 60 & 12 & 32 & 77 \\
\hline 12 & $4-\mathrm{CF}_{3}-\mathrm{C}_{6} \mathrm{H}_{4}$ & 60 & 12 & 99 & 96 \\
\hline 13 & $3-\mathrm{Me}-\mathrm{C}_{6} \mathrm{H}_{4}$ & 60 & 24 & 99 & 91 \\
\hline 14 & $3-\mathrm{Cl}-\mathrm{C}_{6} \mathrm{H}_{4}$ & 60 & 18 & 55 & 96 \\
\hline 15 & $3-\mathrm{Br}-\mathrm{C}_{6} \mathrm{H}_{4}$ & 60 & 24 & 44 & 85 \\
\hline 16 & $3-\mathrm{MeOOC}-\mathrm{C}_{6} \mathrm{H}_{4}$ & 60 & 24 & 91 & 95 \\
\hline 17 & $3-\mathrm{NO}_{2}-\mathrm{C}_{6} \mathrm{H}_{4}$ & 60 & 18 & 40 & 92 \\
\hline
\end{tabular}

addition of 10 equiv of water.

Table 18: Addition reactions of phenylboronic acid to various 3-substituted enones catalysed by $L 9 / P d(T F A)_{2}[47,49]$.

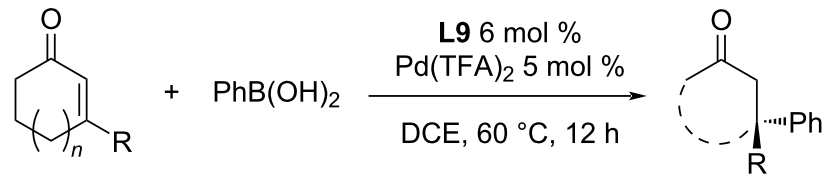

\begin{tabular}{|c|c|c|c|c|}
\hline entry & $n$ & $\mathrm{R}$ & yield (\%) & ee $(\%)$ \\
\hline 1 & 0 & $\mathrm{Me}$ & 84 & 91 \\
\hline 2 & 2 & $\mathrm{Me}$ & 85 & 93 \\
\hline 3 & 1 & Et & 96 & 92 \\
\hline 4 & 1 & $n-\mathrm{Bu}$ & 95 & 91 \\
\hline 5 & 1 & $\mathrm{Bn}$ & 74 & 91 \\
\hline 6 & 1 & Cy & 86 & 85 \\
\hline 8 & 1 & $\mathrm{iPr}$ & 86 & 79 \\
\hline 7 & 1 & cyclopropyl & 68 & 88 \\
\hline 9 & 1 & $\left(\mathrm{CH}_{2}\right)_{3} \mathrm{OBn}$ & 65 & 91 \\
\hline
\end{tabular}

lower temperature [48]. This can be very useful for substrates that can react with traces of $\operatorname{Pd}(0)$ that are formed by minor side reactions. The authors suspected that hexafluorophosphate anions stabilize the cationic Pd species and result in its in- creased solubility. The impact of the addition of $30 \mathrm{~mol} \%$ $\mathrm{NH}_{4} \mathrm{PF}_{6}$ caused that the product yield was almost doubled even when the temperature was $20{ }^{\circ} \mathrm{C}$ lower (Table 19) [48], while there was only a minimal to no effect on the enantioselectivity 
Table 19: Effect of ammonium hexafluorophosphate as additive on the addition reactions of arylboronic acids to 3-methyl-2-cyclohexanone catalysed by $\mathrm{L} 9 / \mathrm{Pd}(\mathrm{TFA})_{2}[48,50]$

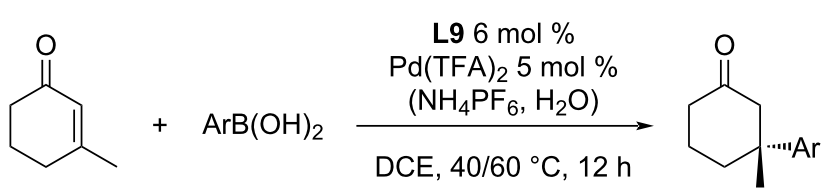

\begin{tabular}{|c|c|c|c|c|c|c|}
\hline \multirow[b]{2}{*}{$\mathrm{Ar}$} & \multicolumn{3}{|c|}{$60^{\circ} \mathrm{C}$, without additive } & \multicolumn{3}{|c|}{$40{ }^{\circ} \mathrm{C}, 30 \mathrm{~mol} \% \mathrm{NH}_{4} \mathrm{PF}_{6}, 5$ equiv $\mathrm{H}_{2} \mathrm{O}$} \\
\hline & entry & yield (\%) & ee $(\%)$ & entry & yield (\%) & ee $(\%)$ \\
\hline $3-\mathrm{Cl}-\mathrm{C}_{6} \mathrm{H}_{4}$ & 1 & 55 & 97 & 6 & 96 & 96 \\
\hline $4-\mathrm{Cl}-\mathrm{C}_{6} \mathrm{H}_{4}$ & 2 & 94 & 95 & $7^{a}$ & $87-91$ & 93 \\
\hline $3-\mathrm{Br}-\mathrm{C}_{6} \mathrm{H}_{4}$ & 3 & 44 & 86 & 8 & 84 & 84 \\
\hline $3-\mathrm{NO}_{2}-\mathrm{C}_{6} \mathrm{H}_{4}$ & 4 & 40 & 92 & 9 & 81 & 91 \\
\hline $2-\mathrm{F}-\mathrm{C}_{6} \mathrm{H}_{4}$ & 5 & 32 & 77 & 10 & 70 & 77 \\
\hline
\end{tabular}

aReaction performed at a $35 \mathrm{mmol}$ scale [50].

(Table 19). Scale-up to a gram-scale was possible, without a major loss of either yield or enantioselectivity (entry 7 , Table 19) [50].

The substrate scope was further expanded with addition reactions of arylboronic acids to 3-acetyl-2-cyclohexenone. The products were isolated in moderate to good yields and excellent enantioselectivities (57-92\%; 90-95\% ee). Furthermore, no 2-arylated products have been detected (Table 20) [49].

Next, the substrate scope was further expanded with the addition reactions of $N$-protected aminophenylboronic acids. The best results in terms of enantioselectivity were achieved when trifluoroacetyl was used as the $N$-protecting group (Table 21) [49].

In other experiments, Stoltz and co-workers showed the ineffectiveness of the $\mathbf{L 9} / \mathrm{Pd}(\mathrm{TFA})_{2}$ catalytic system for the addition of phenylboronic acid to nonsubstituted 2-cyclohexenone, yielding the product with very low enantioselectivity (18\%; entry 1 , Table 22). Furthermore, the addition reaction to a 6,6,3trimethylated substrate gave the product in only very low yield $(9 \%)$, but with high enantioselectivity $(90 \%$ ee; entry 3 , Table 22) [48]. The application of the catalytic system in the addition reaction to an unsaturated lactone yielded the product with both low yield and enantioselectivity $(49 \% ; 57 \%$ ee; entry

Table 20: Addition reactions of arylboronic acids to 3-acetyl-2-cyclohexanone catalysed by L9/Pd(TFA) 2 [49].
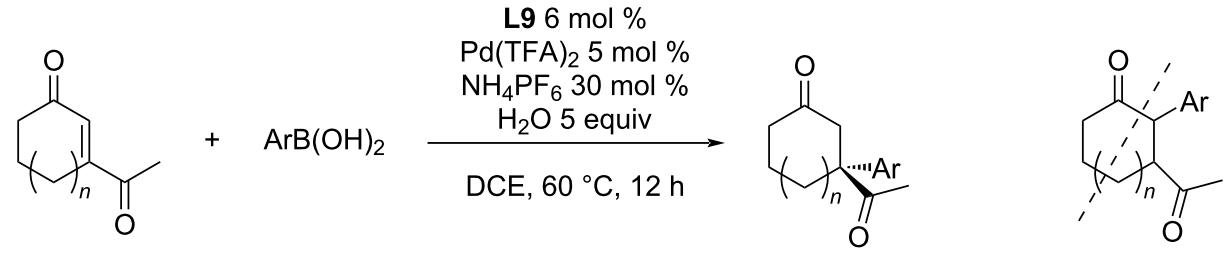

not observed

\begin{tabular}{|c|c|c|c|c|}
\hline entry & $n$ & $\mathrm{Ar}$ & yield (\%) & ee $(\%)$ \\
\hline 1 & 1 & $4-\mathrm{Cl}-\mathrm{C}_{6} \mathrm{H}_{4}$ & 85 & 96 \\
\hline 2 & 1 & $4-\mathrm{F}-\mathrm{C}_{6} \mathrm{H}_{4}$ & 92 & 90 \\
\hline 3 & 1 & $3-\mathrm{Me}-\mathrm{C}_{6} \mathrm{H}_{4}$ & 66 & 92 \\
\hline 4 & 1 & 3- $\left(\mathrm{CF}_{3} \mathrm{CONH}\right)-4-\mathrm{Me}-\mathrm{C}_{6} \mathrm{H}_{3}$ & 73 & 91 \\
\hline 5 & 0 & $\mathrm{Ph}$ & 72 & 93 \\
\hline 6 & 0 & $3-\mathrm{Me}-\mathrm{C}_{6} \mathrm{H}_{4}$ & 72 & 90 \\
\hline 7 & 0 & $4-\mathrm{F}-\mathrm{C}_{6} \mathrm{H}_{4}$ & 57 & 92 \\
\hline
\end{tabular}


Table 21: Addition reactions of $N$-protected aminophenylboronic acids to 3-methyl-2-cyclohexanone catalysed by $L$ (9/Pd(TFA) 2 [49].

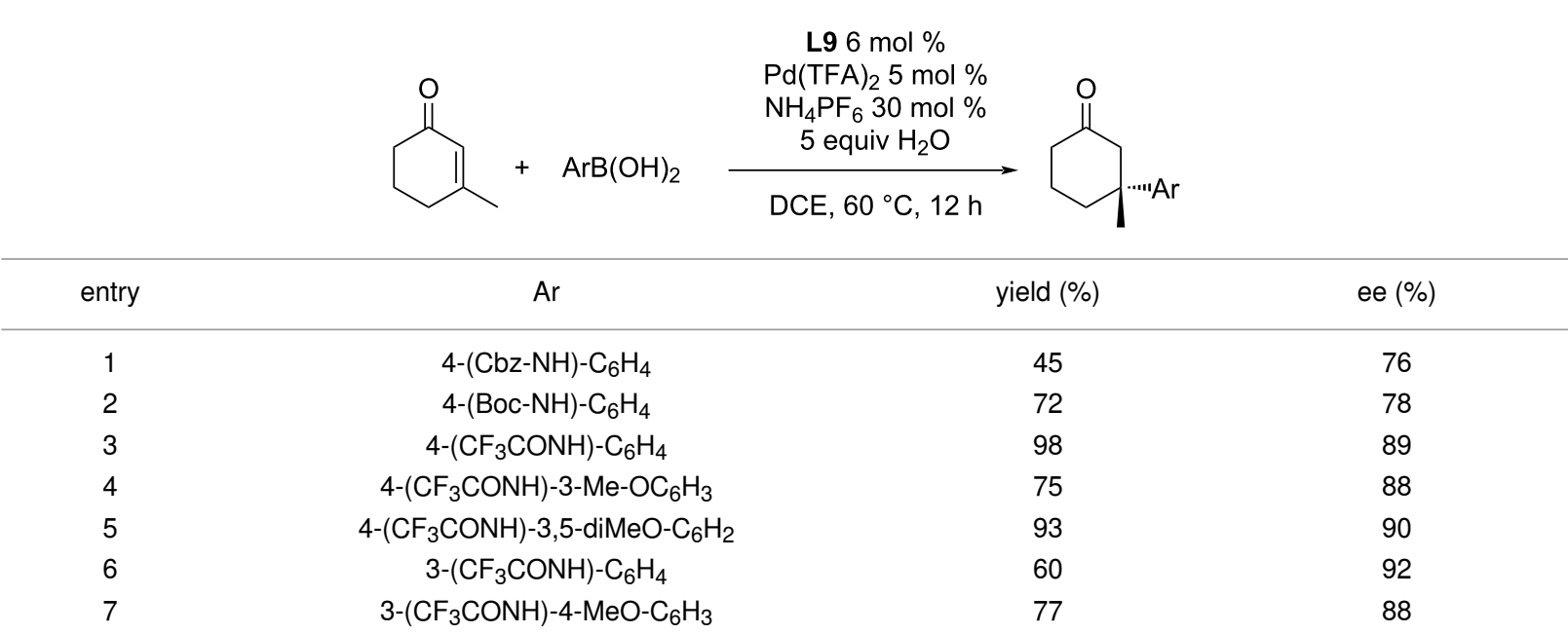

Table 22: Addition reaction of phenylboronic acid to various enones, lactones, and chromones catalysed by $L 9 / \operatorname{Pd}(T F A)_{2}[48,51]$.<smiles>O=C1C=C(P)CCC1</smiles><smiles>[X]C1=CC(C)=CCC1</smiles>

$A R=H$ B $\mathrm{R}=\mathrm{Me}$

$\mathrm{CX}=\mathrm{CMe}_{2}$<smiles>[R]c1cc(=O)c2ccccc2o1</smiles>

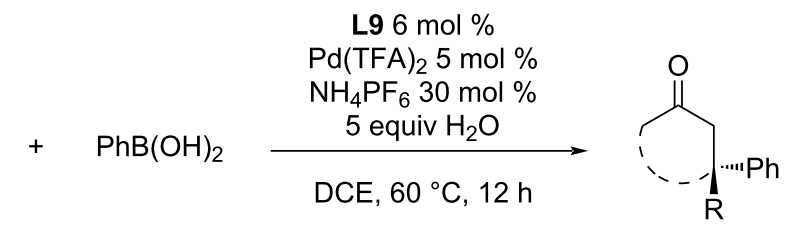

$E R=H$

$\mathbf{F} \mathrm{R}=\mathrm{Me}$

e

.

\begin{tabular}{cccc}
\hline 1 & A & $87\left(\right.$ no $\left.\mathrm{NH}_{4} \mathrm{PF}_{6}\right)$ & 18 \\
2 & B & 99 & 93 \\
3 & C & 90 & 90 \\
4 & D & $49^{\mathrm{a}}$ & 97 \\
5 & E & 91 & 94 \\
6 & F & 0 & - \\
\hline
\end{tabular}

\begin{tabular}{cccc}
\hline entry & substrate & yield (\%) & ee $(\%)$ \\
\hline 1 & A & $87\left(\right.$ no NH$\left._{4} \mathrm{PF}_{6}\right)$ & 18 \\
2 & B & 99 & 93 \\
3 & C & 9 . & 90 \\
4 & D & 49 & 57 \\
5 & E & 91 & 94 \\
6 & F & 0 & - \\
\hline
\end{tabular}

ee $(\%)$

aReaction temperature $40^{\circ} \mathrm{C}$.

4, Table 22) [48]. Finally, the catalytic system failed in the addition reaction with 2-methylchromone and did not yield the expected product, however, it proved to be highly effective for the addition reaction to unsubstituted chromone (91\%; 94\% ee; entry 5, Table 22) [51].

According to these findings, Stoltz and co-workers tested the catalytic system with a library of different chromones for the addition of various boronic acids. The substituted flavanones were obtained with moderate to good yields (36-96\%) and usually very high levels of enantioselectivity (up to $98 \%$ ee; entries 1-29, Table 23) [51]. Also, the addition reaction to the structurally similar $\mathrm{N}$-Cbz-4-quinolone was tested, resulting in the corresponding products with only low to moderate yields (31-65\%) and moderate to good enantioselectivities (40-89\% ee; entries 30-38, Table 23) [51].

In 2018, Wang et al. applied the optimised reaction conditions for the synthesis of various compounds that could be potentially usable for the treatment of cystic fibrosis (Scheme 10) [5].

The large-scale synthesis ( $>130 \mathrm{~g}$ ) of the most successful hit was later published by Greszler et al. (Scheme 11) [6]. 
Table 23: Addition reactions of arylboronic acids to substituted chromones and $\mathrm{N}$-Cbz-4-quinolones catalysed by $\mathrm{L9} / \mathrm{Pd}(\mathrm{TFA})_{2}$ [51].

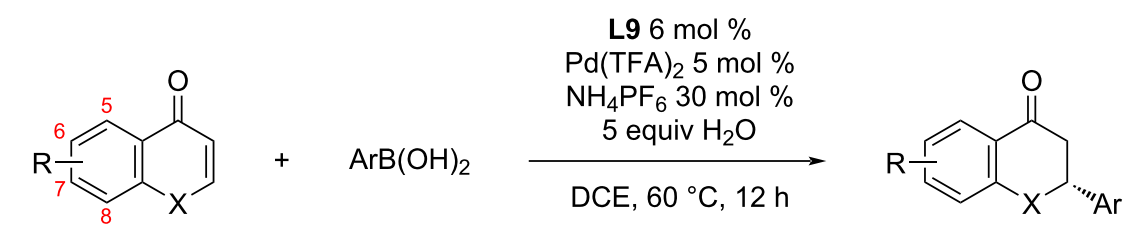

\begin{tabular}{|c|c|c|c|c|c|}
\hline entry & $x$ & $\mathrm{R}$ & $\operatorname{Ar}$ & yield (\%) & ee $(\%)$ \\
\hline 1 & $\mathrm{O}$ & $\mathrm{H}$ & $\mathrm{Ph}$ & 91 & 94 \\
\hline 2 & $\mathrm{O}$ & $\mathrm{H}$ & $2-\mathrm{F}-\mathrm{C}_{6} \mathrm{H}_{4}$ & 50 & 76 \\
\hline 3 & $\mathrm{O}$ & $\mathrm{H}$ & 3-Me- $\mathrm{C}_{6} \mathrm{H}_{4}$ & 66 & 90 \\
\hline 4 & $\mathrm{O}$ & $\mathrm{H}$ & 3-MeOOC- $\mathrm{MeC}_{6} \mathrm{H}_{4}$ & 72 & 93 \\
\hline 5 & $\mathrm{O}$ & $\mathrm{H}$ & $3-\mathrm{Br}-\mathrm{C}_{6} \mathrm{H}_{4}$ & 40 & 89 \\
\hline 6 & $\mathrm{O}$ & $\mathrm{H}$ & 3- $\left(\mathrm{CF}_{3} \mathrm{CONH}\right)-\mathrm{C}_{6} \mathrm{H}_{4}$ & 77 & 98 \\
\hline 7 & $\mathrm{O}$ & $\mathrm{H}$ & $3-\mathrm{Cl}-\mathrm{C}_{6} \mathrm{H}_{4}$ & 52 & 94 \\
\hline 8 & $\mathrm{O}$ & $\mathrm{H}$ & 4-Me- $\mathrm{C}_{6} \mathrm{H}_{4}$ & 64 & 94 \\
\hline 9 & $\mathrm{O}$ & $\mathrm{H}$ & $4-\mathrm{Et}-\mathrm{C}_{6} \mathrm{H}_{4}$ & 36 & 85 \\
\hline 10 & $\mathrm{O}$ & $\mathrm{H}$ & $4-\mathrm{F}-\mathrm{C}_{6} \mathrm{H}_{4}$ & 51 & 90 \\
\hline 11 & 0 & $\mathrm{H}$ & 3,5-diMeO- $\mathrm{C}_{6} \mathrm{H}_{3}$ & 69 & 95 \\
\hline 12 & $\mathrm{O}$ & $\mathrm{H}$ & dibenzofuran-4-yl & 64 & 77 \\
\hline 13 & $\mathrm{O}$ & 6-Ac-5,7-diMe & $\mathrm{Ph}$ & 98 & 90 \\
\hline 14 & $\mathrm{O}$ & 6-Ac-5,7-diMe & $3-\mathrm{Me}-\mathrm{C}_{6} \mathrm{H}_{4}$ & 76 & 88 \\
\hline 15 & $\mathrm{O}$ & 6-Ac-5,7-diMe & $4-\mathrm{Et}-\mathrm{C}_{6} \mathrm{H}_{4}$ & 45 & 86 \\
\hline 16 & $\mathrm{O}$ & 6-Ac-5,7-diMe & $\mathrm{Ph}$ & 79 & 95 \\
\hline 17 & $\mathrm{O}$ & 6-Ac-5,7-diMe & $3-\mathrm{Me}-\mathrm{C}_{6} \mathrm{H}_{4}$ & 84 & 86 \\
\hline 18 & $\mathrm{O}$ & 6-Ac-5,7-diMe & $3-\mathrm{Br}-\mathrm{C}_{6} \mathrm{H}_{4}$ & 65 & 95 \\
\hline 19 & $\mathrm{O}$ & 6-Ac-5,7-diMe & $4-\mathrm{F}-\mathrm{C}_{6} \mathrm{H}_{4}$ & 68 & 91 \\
\hline 20 & $\mathrm{O}$ & 6-Ac-5,7-diMe & 3-MeOOC- $\mathrm{C}_{6} \mathrm{H}_{4}$ & 90 & 86 \\
\hline 21 & $\mathrm{O}$ & 6-Ac-5,7-diMe & dibenzofuran-4-yl & 70 & 83 \\
\hline 22 & $\mathrm{O}$ & 5,7-diMe & $\mathrm{Ph}$ & 84 & 93 \\
\hline 23 & $\mathrm{O}$ & 5,7-diMe & 4- $\left(\mathrm{CF}_{3} \mathrm{CONH}\right)-3-\mathrm{MeO}-\mathrm{C}_{6} \mathrm{H}_{3}$ & 80 & 95 \\
\hline 24 & $\mathrm{O}$ & 7-OAc & $\mathrm{Ph}$ & 77 & 92 \\
\hline 25 & $\mathrm{O}$ & 7-OH & $\mathrm{Ph}$ & 77 & 93 \\
\hline 26 & $\mathrm{O}$ & $7-\mathrm{OH}$ & $3-\mathrm{Me}-\mathrm{C}_{6} \mathrm{H}_{4}$ & 66 & 90 \\
\hline 27 & $\mathrm{O}$ & 7-OH & $4-\mathrm{F}-\mathrm{C}_{6} \mathrm{H}_{4}$ & 50 & 93 \\
\hline 28 & 0 & 7-MeO & $\mathrm{Ph}$ & 96 & 94 \\
\hline 29 & $\mathrm{O}$ & 7-MeO & 3- $\mathrm{MeOOC}-\mathrm{C}_{6} \mathrm{H}_{4}$ & 81 & 96 \\
\hline 30 & $\mathrm{NCbz}$ & $\mathrm{H}$ & $\mathrm{Ph}$ & 50 & 80 \\
\hline 31 & $\mathrm{NCbz}$ & $\mathrm{H}$ & 3- $\left(\mathrm{CF}_{3} \mathrm{CONH}\right)-4-\mathrm{Me}-\mathrm{C}_{6} \mathrm{H}_{3}$ & 45 & 85 \\
\hline 32 & $\mathrm{NCbz}$ & $\mathrm{H}$ & $3-\mathrm{Me}-\mathrm{C}_{6} \mathrm{H}_{4}$ & 51 & 85 \\
\hline 33 & $\mathrm{NCbz}$ & $\mathrm{H}$ & 3,5-diMeO- $\mathrm{C}_{6} \mathrm{H}_{3}$ & 50 & 85 \\
\hline 34 & $\mathrm{NCbz}$ & $\mathrm{H}$ & 3-MeOOC- $\mathrm{C}_{6} \mathrm{H}_{4}$ & 34 & 60 \\
\hline 35 & $\mathrm{NCbz}$ & $\mathrm{H}$ & $4-\mathrm{F}-\mathrm{C}_{6} \mathrm{H}_{4}$ & 65 & 89 \\
\hline 36 & $\mathrm{NCbz}$ & $\mathrm{H}$ & $4-\mathrm{Me}-\mathrm{C}_{6} \mathrm{H}_{4}$ & 45 & 67 \\
\hline 37 & $\mathrm{NCbz}$ & $\mathrm{H}$ & 4-MeO- $\mathrm{C}_{6} \mathrm{H}_{4}$ & 36 & 54 \\
\hline 38 & $\mathrm{NCbz}$ & $\mathrm{H}$ & dibenzofuran-4-yl & 31 & 40 \\
\hline
\end{tabular}

In 2019, another expansion of the substrate scope for the synthesis of substituted flavanones was done by Liu et al. (Table 24). The prepared flavanones were further tested for their cancerostatic activity [7].
In 2019, Timmerman et al. applied the asymmetric addition of phenylboronic acid to a chromone derivative for the total syntheses of (-)-caesalpinnone A and (-)-caesalpinflavan B (Scheme 12) [9]. 


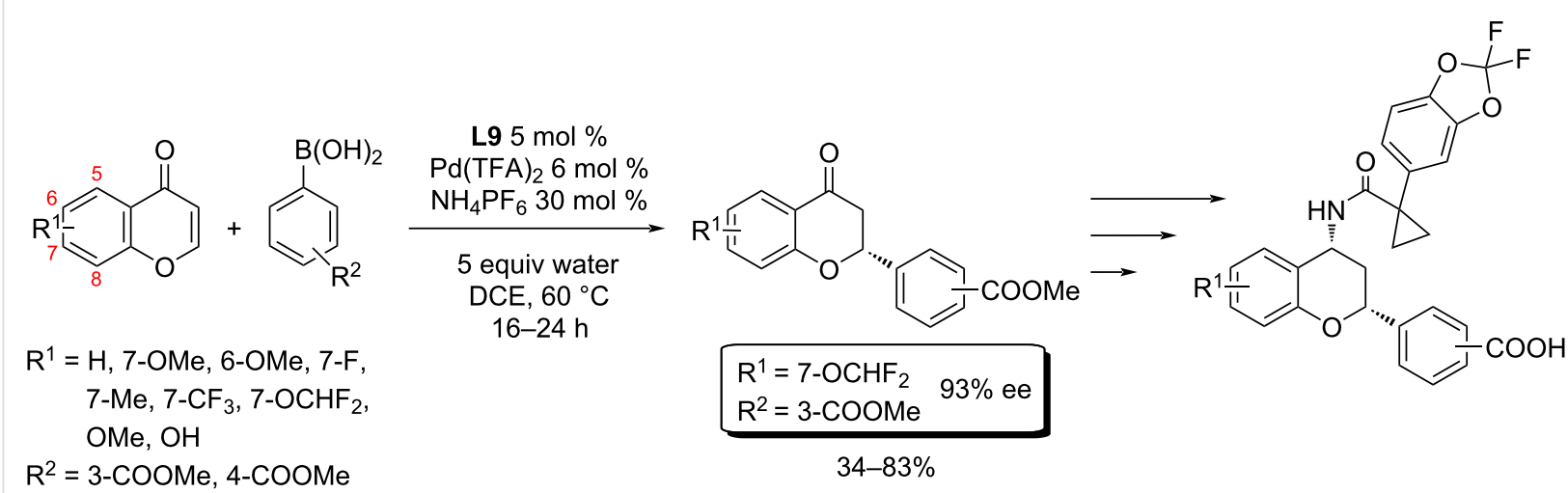

Scheme 10: Usage of addition reactions of boronic acids to various chromones in the syntheses of potentially active substances in medicinal chemistry [5].<smiles>COC(C)=O</smiles>

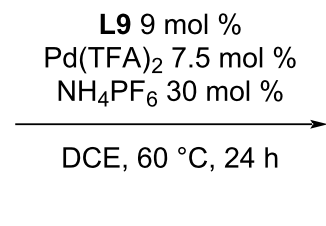<smiles>COC(=O)c1ccc([C@H]2CC(=O)c3ccc(OC)cc3O2)cc1</smiles><smiles>CCC(C)(C)Oc1ccc2c(c1)O[C@H](c1ccc(C(=O)O)cc1)C[C@@H]2NC(=O)C1(c2ccc3c(c2)OC(F)(F)O3)CC1</smiles>

Scheme 11: Multigram-scale synthesis of ABBV-2222 [6].

Table 24: Addition reactions of arylboronic acids to substituted chromones catalysed by $\operatorname{L9} / \operatorname{Pd}(\operatorname{TFA})_{2}[7]$.

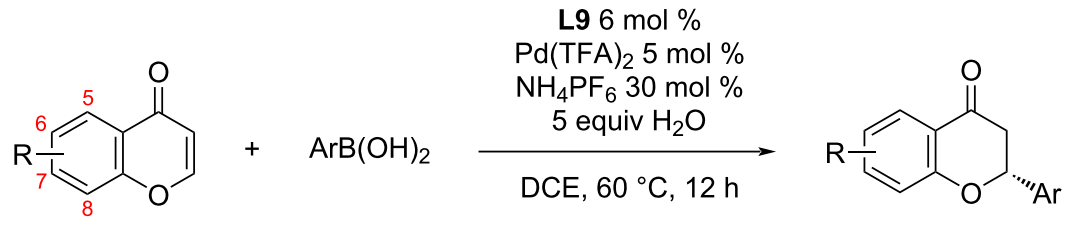

\begin{tabular}{ccccc}
\hline entry & $\mathrm{R}$ & $\mathrm{Ar}$ & yield (\%) & ee (\%) \\
\hline 1 & $\mathrm{H}$ & $\mathrm{Ph}$ & 88 & 94 \\
2 & $\mathrm{H}$ & $3,4-\mathrm{diMeO}-\mathrm{C}_{6} \mathrm{H}_{3}$ & 58 & 89 \\
3 & $\mathrm{H}$ & $4-\mathrm{MeO}-\mathrm{C}_{6} \mathrm{H}_{4}$ & 68 & 95 \\
4 & $\mathrm{H}$ & $3-\mathrm{MeO}-\mathrm{C}_{6} \mathrm{H}_{4}$ & 62 & 86 \\
5 & $\mathrm{H}$ & $3,4,5-$ triOMe- $\mathrm{C}_{6} \mathrm{H}_{2}$ & 70 & 92
\end{tabular}


Table 24: Addition reactions of arylboronic acids to substituted chromones catalysed by L9/Pd(TFA) $[$ [7]. (continued)

\begin{tabular}{|c|c|c|c|c|}
\hline 6 & $\mathrm{H}$ & piperonyl & 59 & 89 \\
\hline 7 & $\mathrm{H}$ & $4-\mathrm{NO}_{2}-\mathrm{C}_{6} \mathrm{H}_{4}$ & 52 & 77 \\
\hline 8 & $\mathrm{H}$ & 4-Me- $\mathrm{C}_{6} \mathrm{H}_{4}$ & 63 & 91 \\
\hline 9 & $\mathrm{H}$ & 3-Me- $\mathrm{C}_{6} \mathrm{H}_{4}$ & 70 & 83 \\
\hline 10 & $\mathrm{H}$ & $4-\mathrm{Cl}-\mathrm{C}_{6} \mathrm{H}_{4}$ & 50 & 96 \\
\hline 11 & $\mathrm{H}$ & $3-\mathrm{Cl}-\mathrm{C}_{6} \mathrm{H}_{4}$ & 58 & 92 \\
\hline 12 & $\mathrm{H}$ & $4-\mathrm{Br}-\mathrm{C}_{6} \mathrm{H}_{4}$ & 49 & 86 \\
\hline 13 & $\mathrm{H}$ & $4-\mathrm{F}-\mathrm{C}_{6} \mathrm{H}_{4}$ & 46 & 75 \\
\hline 14 & $\mathrm{H}$ & 1-naphthyl & 59 & 78 \\
\hline 15 & $\mathrm{H}$ & 2-furyl & 55 & 74 \\
\hline 16 & $\mathrm{H}$ & thiophene-2-yl & 45 & 87 \\
\hline 17 & $\mathrm{H}$ & $4-\mathrm{Me}_{2} \mathrm{~N}-\mathrm{C}_{6} \mathrm{H}_{4}$ & 43 & 83 \\
\hline 18 & $\mathrm{H}$ & 4-Et- $\mathrm{C}_{6} \mathrm{H}_{4}$ & 58 & 77 \\
\hline 19 & $\mathrm{H}$ & 4-MeS- $\mathrm{C}_{6} \mathrm{H}_{4}$ & 72 & 90 \\
\hline 20 & $\mathrm{H}$ & $4-t-\mathrm{Bu}-\mathrm{C}_{6} \mathrm{H}_{4}$ & 66 & 91 \\
\hline 21 & 7-MeO & 4-MeO- $\mathrm{C}_{6} \mathrm{H}_{4}$ & 76 & 90 \\
\hline 22 & $7-\mathrm{OBn}$ & $4-\mathrm{MeO}-\mathrm{C}_{6} \mathrm{H}_{4}$ & 83 & 74 \\
\hline 23 & $7-\mathrm{Br}$ & 4- $\mathrm{MeO}-\mathrm{C}_{6} \mathrm{H}_{4}$ & 70 & 93 \\
\hline 24 & $7-\mathrm{F}$ & 4-MeO- $\mathrm{C}_{6} \mathrm{H}_{4}$ & 52 & 66 \\
\hline 25 & 7-Me & $4-\mathrm{MeO}-\mathrm{C}_{6} \mathrm{H}_{4}$ & 80 & 82 \\
\hline 26 & 6-Cl-7-Me & $4-\mathrm{MeO}-\mathrm{C}_{6} \mathrm{H}_{4}$ & 68 & 79 \\
\hline 27 & 7-Cl-6-Me & 4- $\mathrm{MeO}-\mathrm{C}_{6} \mathrm{H}_{4}$ & 57 & 70 \\
\hline 28 & 6-Cl & $4-\mathrm{MeO}-\mathrm{C}_{6} \mathrm{H}_{4}$ & 70 & 95 \\
\hline 29 & $6-\mathrm{Br}$ & $4-\mathrm{MeO}-\mathrm{C}_{6} \mathrm{H}_{4}$ & 59 & 76 \\
\hline 30 & $6-\mathrm{F}$ & $4-\mathrm{MeO}-\mathrm{C}_{6} \mathrm{H}_{4}$ & 60 & 80 \\
\hline 31 & $6-\mathrm{MeO}$ & $4-\mathrm{MeO}-\mathrm{C}_{6} \mathrm{H}_{4}$ & 87 & 94 \\
\hline 32 & $6-\mathrm{Me}$ & $4-\mathrm{MeO}-\mathrm{C}_{6} \mathrm{H}_{4}$ & 44 & 79 \\
\hline 33 & $6-\mathrm{NO}_{2}$ & $4-\mathrm{MeO}-\mathrm{C}_{6} \mathrm{H}_{4}$ & 67 & 95 \\
\hline 34 & 6,7-diMeO & $4-\mathrm{MeO}-\mathrm{C}_{6} \mathrm{H}_{4}$ & 48 & 85 \\
\hline 35 & 5-MeO & $4-\mathrm{MeO}-\mathrm{C}_{6} \mathrm{H}_{4}$ & 75 & 94 \\
\hline 36 & 5,7-diOMe & $4-\mathrm{MeO}-\mathrm{C}_{6} \mathrm{H}_{4}$ & 65 & 89 \\
\hline 37 & 6,8-diCl & $4-\mathrm{MeO}-\mathrm{C}_{6} \mathrm{H}_{4}$ & 83 & 93 \\
\hline 38 & benzo $[f]$ & $4-\mathrm{MeO}-\mathrm{C}_{6} \mathrm{H}_{4}$ & 88 & 77 \\
\hline 39 & 5,7-bis(MEM) & $4-\mathrm{MeO}-\mathrm{C}_{6} \mathrm{H}_{4}$ & 74 & 88 \\
\hline 40 & $7-\mathrm{OCH}_{2} \mathrm{OMe}$ & $4-\mathrm{MeO}-\mathrm{C}_{6} \mathrm{H}_{4}$ & 47 & 81 \\
\hline 41 & 5,7-diOH & $4-\mathrm{MeO}-\mathrm{C}_{6} \mathrm{H}_{4}$ & 86 & - \\
\hline 42 & $5-\mathrm{OH}$ & $4-\mathrm{MeO}-\mathrm{C}_{6} \mathrm{H}_{4}$ & 89 & - \\
\hline
\end{tabular}

Mechanistic studies of this catalytic system were also made by Stoltz's group. A linear relationship between the ee of the catalyst and the product has been found [48]. That means that the catalytically relevant species is monomeric $\mathrm{Pd}-\mathrm{PyOx}$. This was further supported by a mass spectrometric study [52]. The catalytic cycle was also suggested in accordance with DFT calculations and mechanistic studies (Scheme 13) $[48,49]$. The key step for both, the enantioselectivity and turnover, is the migratory insertion via TS1 (Scheme 13). The stereochemistry is controlled mainly by the hydrogen repulsion of the methylene group neighbouring the keto group of the enone with the $t$ - Bu group of the ligand $\mathbf{L 9}$.
Another interesting example for the application of this reaction in the preparation of precursors of natural molecules was reported by Li et al. in 2014. They presented the synthesis of terpenoid precursors ((+)-taiwaniaquinone $\mathrm{H}$ and (+)-dichroanone) [10] starting from 3-methyl-2-cyclohexenone using the $\mathbf{L 9} / \mathrm{Pd}(\mathrm{TFA})_{2}$ catalytic system. The precursors were prepared in good yields (42-98\%) with high enantioselectivities (85-99\% ee; entry 1; Table 25) and used in the total synthesis of terpenoids (Scheme 14) [10].

In the same year, these terpenoids were also prepared by the Stoltz group [11]. Arylboronic acids bearing the appropriate 


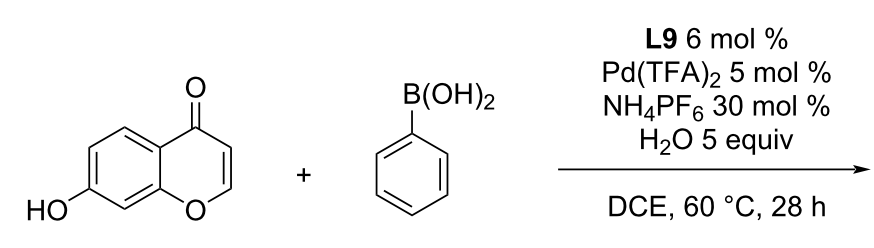<smiles>O=C(/C=C/c1ccccc1)c1ccc(O)c(C2CC(c3ccccc3)Oc3cc(O)ccc32)c1O</smiles>

(-)-caesalpinflavan B<smiles>O=C1C[C@H](c2ccccc2)Oc2cc(O)ccc21</smiles><smiles>[3H][13IH]</smiles>

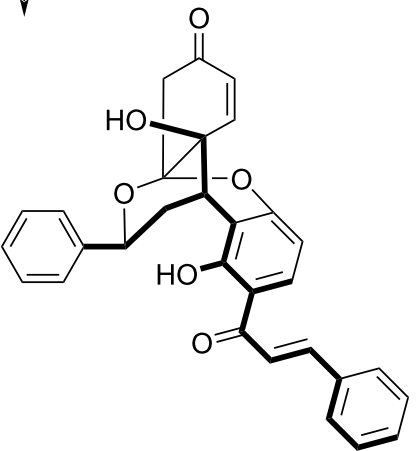

(-)-caesalpinnone A

Scheme 12: Application of the asymmetric addition of phenylboronic acid to a chromone derivative for the total syntheses of the natural products (-)-caesalpinnone A and (-)-caesalpinflavan B [9].

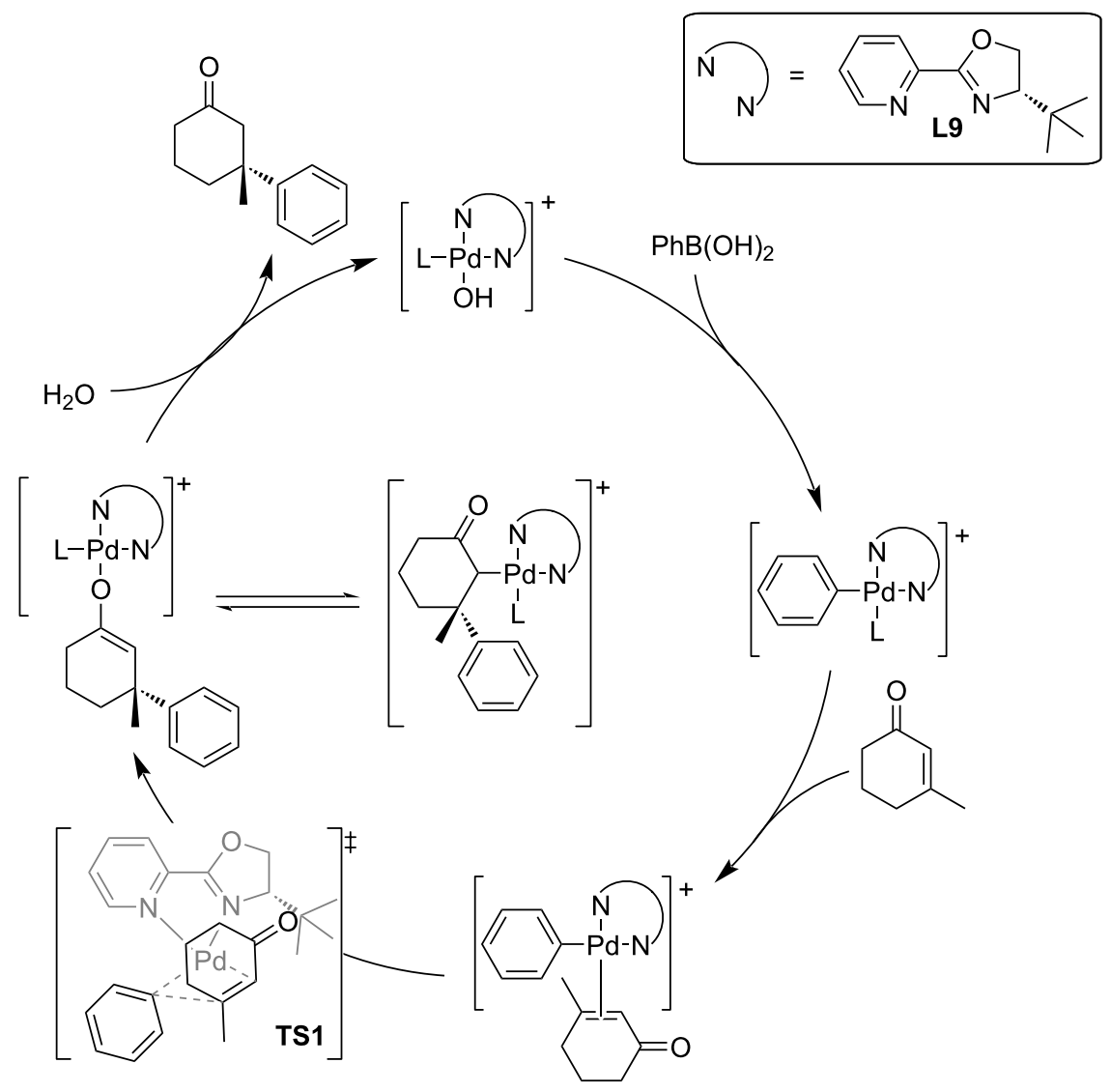

Scheme 13: Plausible catalytic cycle for the addition of phenylboronic acid to 3-methyl-2-cyclohexenone catalysed by L9/Pd(TFA) 2 [48,49]. 
Table 25: Addition of various highly functionalized arylboronic acids to 3-methylcyclohexanone for the synthesis of terpenoids [10,11].

\begin{tabular}{clcccc} 
& & \\
\hline
\end{tabular}

aReaction performed at $60^{\circ} \mathrm{C}$ for $48 \mathrm{~h}$.<smiles>CC1(c2cc(O[14CH3])c(Br)c(O[14CH3])c2)CCCC(=O)C1</smiles>

$(>99 \%$ ee) OPiv

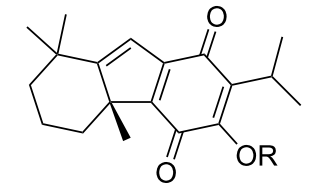

$\mathrm{R}=\mathrm{Me},(+)$-taiwaniachinone $\mathrm{H}$ $\mathrm{R}=\mathrm{H},(+)$-dichroanone

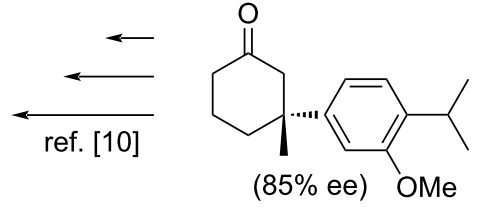

Scheme 14: Total syntheses of naturally occurring terpenoids [10,11].

functional groups were identified and the addition reactions to 3-methyl-2-cyclohexenone were studied (entries 2-6, Table 25) [11]. The product, which was obtained in an almost quantitative yield and practically maximal possible enantioselectivity (entry 5 in Table 25), was subsequently converted to suitable intermediates for the synthesis of naturally occurring terpenoids (Scheme 14) [11].
Another possible use of this catalytic system was demonstrated by the groups of Lautens and Hashmi [4]. The starting enone, prepared by the $\mathrm{Au}(\mathrm{I})$-catalysed Rautenstrauch rearrangement, was subjected to the addition reaction with phenylboronic acid (Scheme 15). Without isolation of the intermediate, the protecting group was removed and the product was obtained in $88 \%$ yield and $80 \%$ ee. The enantiomeric excess of the ob-

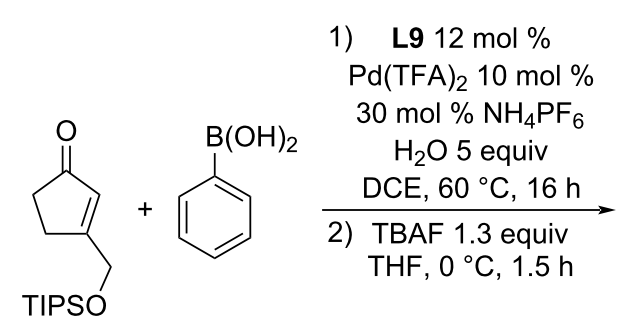

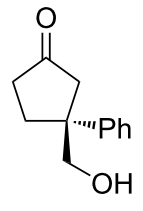

$88 \%$

$80 \%$ ee

( $97 \%$ ee after double recrystallization)

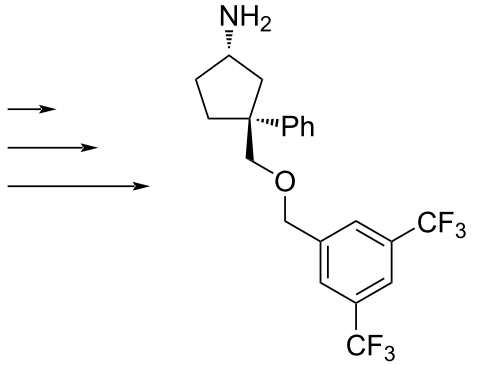

Scheme 15: Use of the L9/Pd(TFA $)_{2}$ catalytic system for the synthesis of intermediates of biologically active compounds [4]. 
tained (S)-3-(hydroxymethyl)-3-phenyl-2-cyclopentanone could be increased by double recrystallization to up to $97 \%$ ee (Scheme 15) [4].

The catalytic system $\mathbf{L 9} / \mathrm{Pd}(\mathrm{TFA})_{2}$ was further used in the work published in 2020 by Bisai et al. for the addition of 4-tolylboronic acid to 3-methyl-2-cyclohexenone in the total synthesis of the aromatic sesquiterpene (-)-ar-tenuifolene (Scheme 16) [12].

Later in 2020, Bisai et al. published the application of the $\mathbf{L 9} / \mathrm{Pd}(\mathrm{TFA})_{2}$ catalytic system for the preparation of the enan- tiomers of other sesquiterpenoids by the addition reactions of tolylboronic acids to 3-methyl-2-cyclopentenone (Scheme 17) [13].

Also in 2020, Ochi et al. expanded the synthetic usability of 3-alkyl-3-arylcyclopentanones by developing a method for their $\mathrm{Rh}$-catalysed isomerisation to 1-tetralones with $>99 \%$ stereoretention (Scheme 18) [53].

To obtain the starting material for the transformation (Scheme 18), the authors have described the addition of arylboronic acids to 3 -substituted-2-cyclopentenones (Table 26)

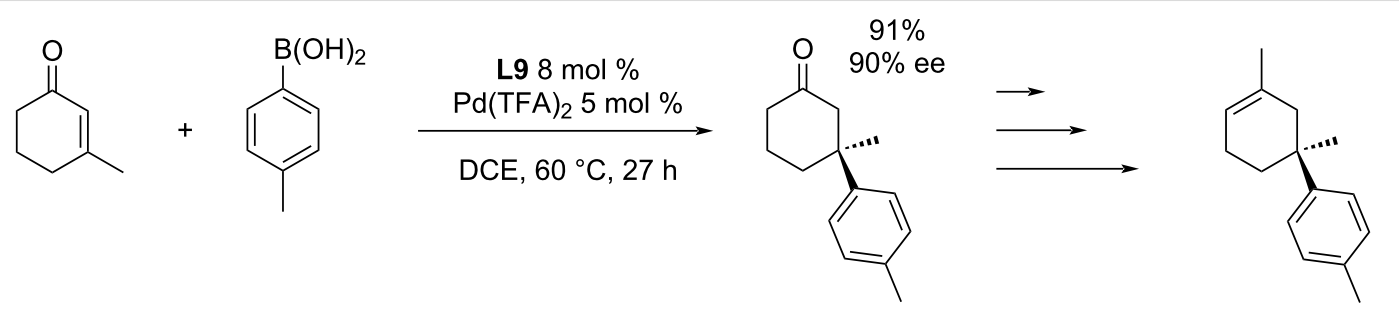

(-)-ar-tenuifolene

Scheme 16: Usage of a Michael addition catalysed by L9/Pd(TFA $)_{2}$ in the total synthesis of (-)-ar-tenuifolene [12].

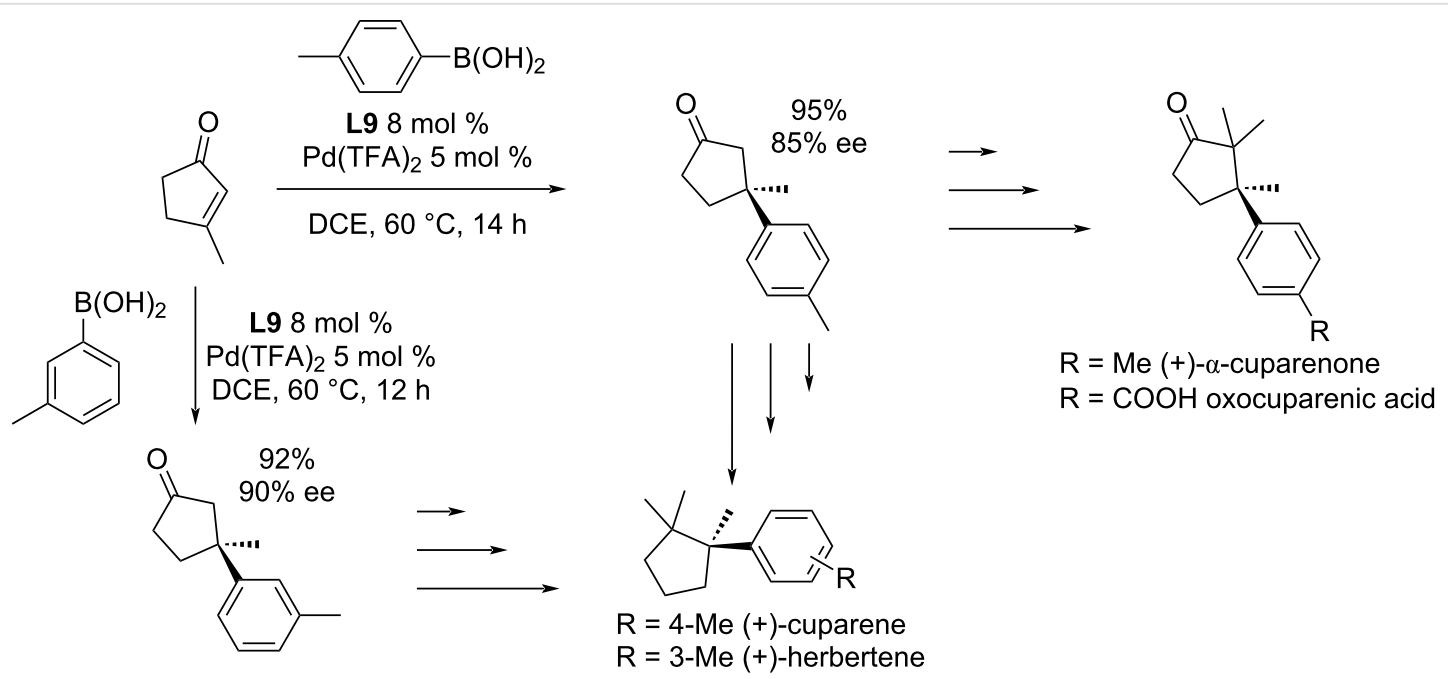

Scheme 17: Synthesis of terpenoids by Michael addition to 3-methyl-2-cyclopentenone [13]
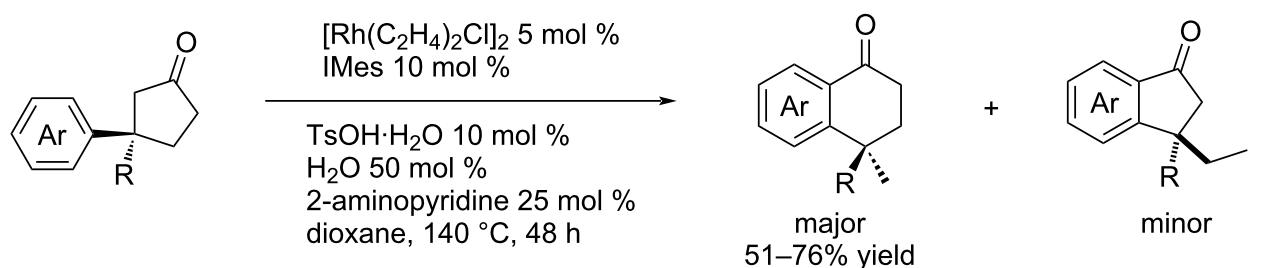

Scheme 18: Rh-catalysed isomerisation of 3-alkyl-3-arylcyclopentanones to 1-tetralones [53]. 
Table 26: Addition reactions of arylboronic acids to 3-alkyl-2-cyclopentenones catalysed by L9/Pd(TFA) 2 [53].

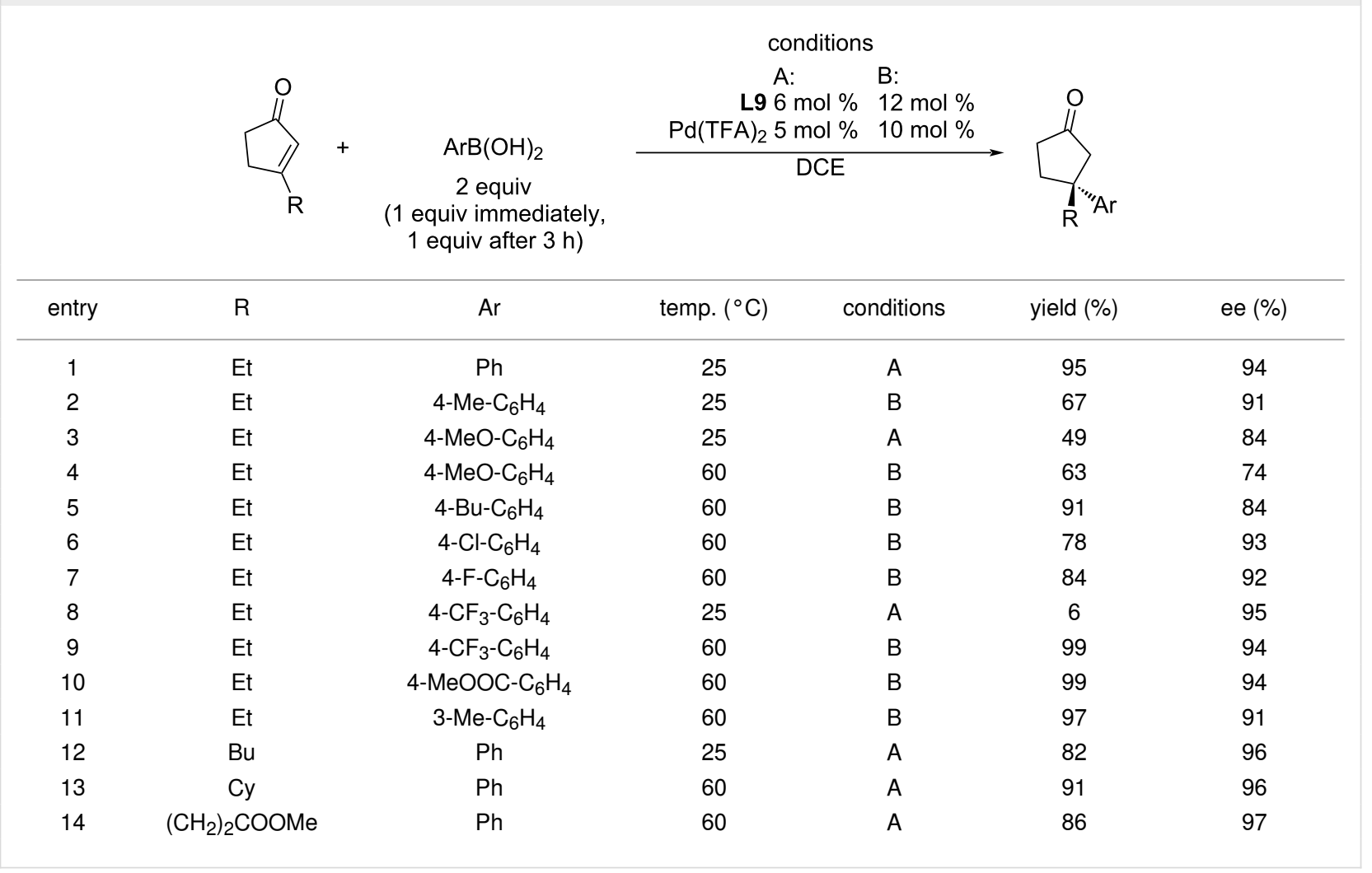

either by using Stoltz's catalytic system L9/Pd(TFA) $)_{2}$ or by its simple modification (temperature, catalyst loading) combined with the iterative addition of boronic acids (1 equiv immediately and 1 equiv after 3 hours) [49].

Following Stoltz's works [11,27,47-49,51,52], Stanley et al. published the first example for the formation of all-carbon quaternary stereocentres, in an aqueous medium (Scheme 19) [54] by the addition of phenylboronic acid to 3-methyl-2-cyclohexenone using the $\mathbf{L 9} / \mathrm{Pd}(\mathrm{TFA})_{2}$ catalytic system. Compared to the reaction in DCE (93\% yield, 92\% ee,) [47], a slightly lower yield and significantly lower enantioselectivity were obtained in water as the solvent ( $86 \%$ yield, $71 \%$ ee, Scheme 19) [54].

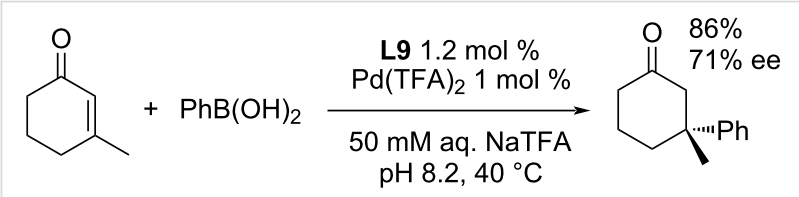

Scheme 19: Addition reaction of phenylboronic acid to 3-methyl-2cyclohexenone catalysed by $\mathrm{L9} / \mathrm{Pd}(\mathrm{TFA})_{2}$ in water [54].

Significant successes of the Stanley group were achieved in the subsequent study of the as yet unexplored asymmetric addition of arylboronic acids to 3-aryl-2-cyclohexenones, where double benzyl quaternary stereogenic centres were formed [55]. The initial studies showed the formation of significant amounts of protodeborylation products, small amounts of boronic acid homocoupling products, and the corresponding phenols as boronic acid oxidation products. To optimise the yields, the amount of the boronic acid was increased to 3 equiv, which was added gradually ( 1 equiv every 3 hours) [55]. The authors presented interesting results and expanded the range of compounds that could be prepared by this methodology. The obtained results were excellent both in terms of enantioselectivity (up to $91 \%$ ee) and conversion (92\%; Table 27) [55].

In 2018, the very first heterogeneous catalytic system for the addition of arylboronic acids to cyclic enones was introduced by O'Reilly and co-workers [56]. The micellar nanoreactor was tested for the preparation of flavanones. The main advantages of such catalytic system were short reaction times in an aqueous medium and with a very small amount of the catalyst needed (Table 28). The heterogeneous catalyst PdL10b system worked significantly better than the conventional homogeneous synthesis, even when using a significantly higher amount of the PdL10a catalytic species in the homogeneous system. The results were excellent both in terms of enantioselectivities and conversions (up to $98 \%$; up to $83 \%$ ee; Table 28 ). The reuse of the heterogeneous catalyst has not been studied in this case. 
Table 27: Addition reactions of arylboronic acids to 3-aryl-2-cyclohexenones catalysed by $\mathrm{L9} / \mathrm{Pd}(\mathrm{TFA})_{2}$ [55].<smiles>O=C1C=C(Br)CCC1</smiles><smiles>[R]O[Ga]c1ccccc1</smiles>

L9 $12 \mathrm{~mol} \%$ $\underset{\mathrm{Pd}(\mathrm{TFA})_{2} 10 \mathrm{~mol} \%}{\mathrm{DCE}, 80^{\circ} \mathrm{C}, 9 \mathrm{~h}}$

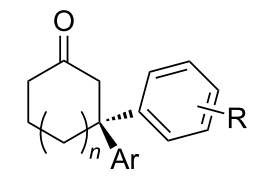

3 equiv

( 1 equiv every $3 \mathrm{~h}$ )

\begin{tabular}{|c|c|c|c|c|c|}
\hline entry & $n$ & $\mathrm{Ar}$ & $\mathrm{R}$ & yield (\%) & ee (\%) \\
\hline $1^{a}$ & 1 & $4-\mathrm{MeO}-\mathrm{C}_{6} \mathrm{H}_{4}$ & 4-Me & $83(81)^{b, c}$ & $89(87)^{b, c}$ \\
\hline $2^{a}$ & 1 & $4-\mathrm{MeO}-\mathrm{C}_{6} \mathrm{H}_{4}$ & $\mathrm{H}$ & $70^{\mathrm{c}}$ & $87^{c}$ \\
\hline 3 & 1 & $4-\mathrm{MeO}-\mathrm{C}_{6} \mathrm{H}_{4}$ & 4-Ph & 92 & 90 \\
\hline 4 & 1 & $4-\mathrm{MeO}-\mathrm{C}_{6} \mathrm{H}_{4}$ & $4-\mathrm{Cl}$ & 55 & 83 \\
\hline 5 & 1 & $4-\mathrm{MeO}-\mathrm{C}_{6} \mathrm{H}_{4}$ & 4-F & 49 & 91 \\
\hline 6 & 1 & $4-\mathrm{MeO}-\mathrm{C}_{6} \mathrm{H}_{4}$ & 4-COOMe & 39 & 87 \\
\hline 7 & 1 & $4-\mathrm{MeO}-\mathrm{C}_{6} \mathrm{H}_{4}$ & $4-\mathrm{CF}_{3}$ & 38 & 82 \\
\hline 8 & 1 & $4-\mathrm{MeO}-\mathrm{C}_{6} \mathrm{H}_{4}$ & 3-Me & 88 & 90 \\
\hline 9 & 1 & $4-\mathrm{MeO}-\mathrm{C}_{6} \mathrm{H}_{4}$ & 3-MeO & 60 & 90 \\
\hline 10 & 1 & $4-\mathrm{MeO}-\mathrm{C}_{6} \mathrm{H}_{4}$ & $3-\mathrm{Cl}$ & 35 & 85 \\
\hline 11 & 1 & $4-\mathrm{MeO}-\mathrm{C}_{6} \mathrm{H}_{4}$ & $3-\mathrm{F}$ & 18 & 84 \\
\hline 12 & 1 & $4-\mathrm{MeO}-\mathrm{C}_{6} \mathrm{H}_{4}$ & $2-\mathrm{F}$ & 23 & 81 \\
\hline 13 & 1 & $4-\mathrm{MeO}-\mathrm{C}_{6} \mathrm{H}_{4}$ & 3-F-4-MeO & 66 & 88 \\
\hline 14 & 1 & $4-\mathrm{MeO}-\mathrm{C}_{6} \mathrm{H}_{4}$ & $3,4-\left(\mathrm{CH}_{2} \mathrm{O}_{2}\right)$ & 44 & 90 \\
\hline 15 & 1 & $4-\mathrm{MeO}-\mathrm{C}_{6} \mathrm{H}_{4}$ & 3,4-diMe & $36^{c}$ & 85 \\
\hline 16 & 1 & $4-\mathrm{MeO}-\mathrm{C}_{6} \mathrm{H}_{4}$ & 3,5-diMe & $38^{c}$ & 90 \\
\hline 17 & 1 & $4-\mathrm{MeO}-\mathrm{C}_{6} \mathrm{H}_{4}$ & 3,4,5-triMeO & 67 & 78 \\
\hline 18 & 1 & $\mathrm{Ph}$ & 4-Me & 70 & 87 \\
\hline 19 & 1 & $4-\mathrm{NMe}_{2}-\mathrm{C}_{6} \mathrm{H}_{4}$ & 4-Me & 36 & 91 \\
\hline 20 & 1 & $4-\mathrm{F}-\mathrm{C}_{6} \mathrm{H}_{4}$ & 4-Me & 74 & 89 \\
\hline 21 & 1 & $4-\mathrm{CF}_{3}-\mathrm{C}_{6} \mathrm{H}_{4}$ & 4-Me & 54 & 90 \\
\hline 22 & 1 & 3- $\mathrm{MeO}-\mathrm{C}_{6} \mathrm{H}_{4}$ & 4-Me & 72 & 93 \\
\hline 23 & 1 & $2-\mathrm{MeO}-\mathrm{C}_{6} \mathrm{H}_{4}$ & 4-Me & 28 & 80 \\
\hline 24 & 1 & $1 H$-indol-3-yl & 4-Me & 41 & 77 \\
\hline 25 & 1 & $\mathrm{Ph}$ & 3-Me & 76 & 88 \\
\hline 26 & 1 & $\mathrm{Ph}$ & 4-MeO & 44 & 80 \\
\hline 27 & 1 & $4-\mathrm{Me}-\mathrm{C}_{6} \mathrm{H}_{4}$ & $\mathrm{H}$ & $70^{c}$ & 88 \\
\hline 28 & 0 & $4-\mathrm{MeO}-\mathrm{C}_{6} \mathrm{H}_{4}$ & 4-Me & 60 & 87 \\
\hline
\end{tabular}

a $5 \mathrm{~mol} \% \mathrm{Pd}$ catalyst were used; bon a $1 \mathrm{mmol}$ scale; cin the presence of 5 equiv $\mathrm{H}_{2} \mathrm{O}$.

In 2020, our group reported the first heterogeneous polystyrenesupported recyclable catalyst for the asymmetric conjugate additions of arylboronic acids to five and six-membered enones (Table 29) [57]. For most of the substrates, the enantioselectivity was similar to the values reported for the homogeneous L9/Pd(TFA) 2 system. The conversions obtained were a bit worse, especially for the more sterically demanding boronic acids (Table 29).

Under the optimised conditions, we were able to use the catalyst in 6 runs with no significant drop in the enantioselectivity and only a small decrease in the conversion (Table 30). The main issues with transferring into heterogeneous conditions were the impossibility of using water as a proton source and the observed reduction of $\mathrm{Pd}(\mathrm{II})$ to $\mathrm{Pd}(0)$. HFIP was used as a proton source instead and $\mathrm{Pd}(0)$ was reoxidised to $\mathrm{Pd}(\mathrm{II})$ by $p$-chloranil between the individual cycles. The ratio PS-PyOx:Pd(TFA) 2 showed a crucial role in the enantioselectivity. Using a higher excess of PS-PyOx allowed achieving a higher ee, however, it also caused a faster loss of catalytic activity.

Later in 2020, Zhou et al. used an analogous heterogeneous system as O'Reilly (cf. Table 28) [56,58]. A RAFT polymerisa- 
Table 28: Micellar nanoreactor for the synthesis of substituted flavanones [56].
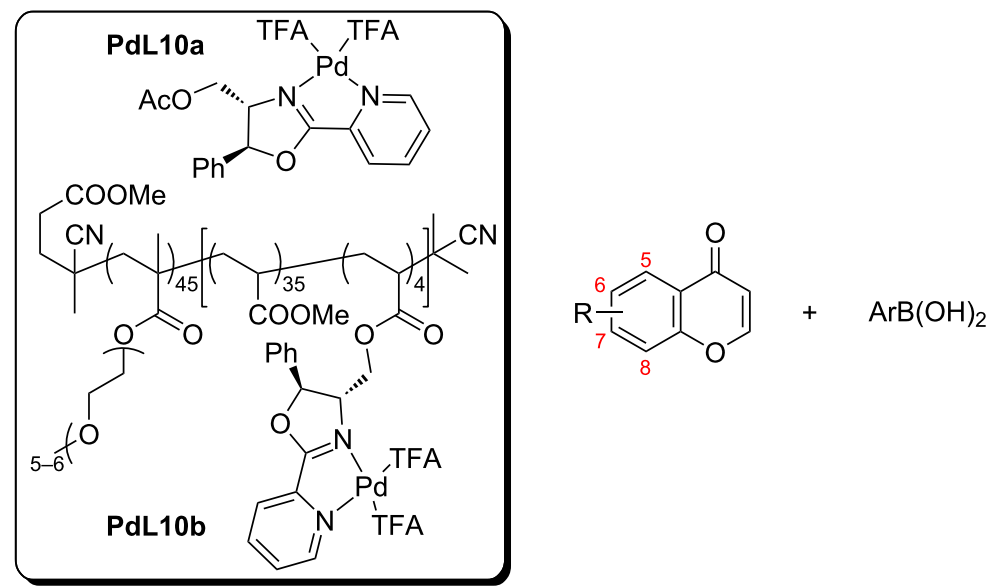

\section{PdL10a $5 \mathrm{~mol} \%$}

DCE/ $\mathrm{H}_{2} \mathrm{O}$

or

PdL10b $0.5 \mathrm{~mol} \%$

$\mathrm{H}_{2} \mathrm{O}, 25^{\circ} \mathrm{C}$

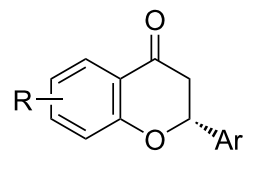

\begin{tabular}{cccccccccc}
\hline & & \multicolumn{4}{c}{ homogeneous system with PdL10a } & \multicolumn{3}{c}{ heterogeneous system with PdL10b } \\
R & Ar & entry & time (h) & yield (\%) & ee (\%) & entry & time (h) & yield (\%) & ee (\%) \\
\hline $\mathrm{H}$ & $\mathrm{Ph}$ & 1 & 24 & 98 & 84 & 5 & 24 & 90 & 80 \\
$\mathrm{H}$ & $\mathrm{Ph}$ & 2 & 24 & $95^{\mathrm{a}}$ & 79 & 6 & 92 & 94 & 82 \\
$\mathrm{H}$ & $4-\mathrm{Cl}-\mathrm{C}_{6} \mathrm{H}_{4}$ & 3 & 24 & 94 & 81 & 7 & 24 & 68 & 76 \\
$6-\mathrm{Cl}$ & $4-\mathrm{Cl}_{-} \mathrm{C}_{6} \mathrm{H}_{4}$ & 4 & 24 & 80 & 83 & 8 & 24 & 32 & 71 \\
\hline
\end{tabular}

a $30 \mathrm{~mol}_{\%} \mathrm{NH}_{4} \mathrm{PF}_{6}$

Table 29: Polystyrene-supported Pd complex PdL11 as catalyst for addition reactions of arylboronic acids to cyclic enones [57].
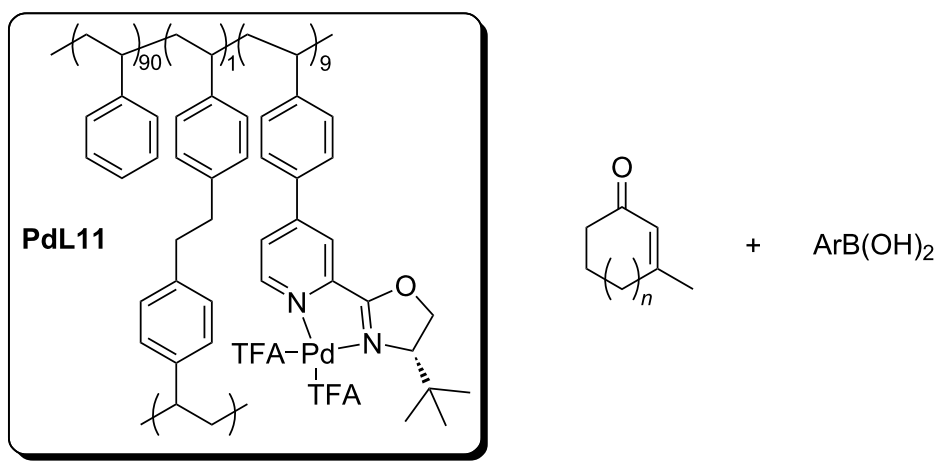

PdL11 $13 \mathrm{~mol} \%$

DCE, $60^{\circ} \mathrm{C}, 24 \mathrm{~h}$

HFIP 5 equiv

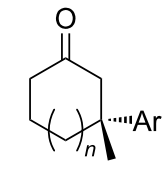

$\begin{array}{ccccc}\text { entry } & n & \mathrm{Ar} & \text { conversion (\%) } & \text { ee (\%) } \\ 1 & 1 & \mathrm{Ph} & 93 & 89 \\ 2 & 1 & 4-\mathrm{Me}^{-} \mathrm{C}_{6} \mathrm{H}_{4} & 94 & 75 \\ 3 & 1 & 4-\mathrm{CF}_{3}-\mathrm{C}_{6} \mathrm{H}_{4} & 85^{\mathrm{a}} & 91 \\ 4 & 1 & 4-\mathrm{Cl}_{6} \mathrm{CH}_{4} & 78^{\mathrm{a}} & 91 \\ 5 & 1 & 4-\mathrm{Ac}_{6} \mathrm{C}_{4} & 52^{\mathrm{a}} & 90 \\ 6 & 1 & 4-\mathrm{BnO}_{6} \mathrm{C}_{6} \mathrm{H}_{4} & 59^{\mathrm{a}} & 58 \\ 7 & 0 & \mathrm{Ph} & 99 & 79 \\ 8 & 0 & 4-\mathrm{Me}-\mathrm{C}_{6} \mathrm{H}_{4} & 92^{\mathrm{a}}(96 \mathrm{~h}) / 99^{\mathrm{b}} & 90 / 87^{\mathrm{b}} \\ 9 & 0 & 4-\mathrm{MeOOC}-\mathrm{C}_{6} \mathrm{H}_{4} & 99^{\mathrm{a}}(96 \mathrm{~h}) / 99^{\mathrm{b}} & 91 / 96^{\mathrm{b}} \\ 10 & 0 & 3-\mathrm{MeOOC}-\mathrm{C}_{6} \mathrm{H}_{4} & 91^{\mathrm{a}}(72 \mathrm{~h}) / 99^{\mathrm{b}} & \end{array}$

a30 mol \% $\mathrm{NH}_{4} \mathrm{PF}_{6}$; ; homogenous conditions: $5 \mathrm{~mol} \% \mathrm{Pd}(\mathrm{TFA})_{2}, 6 \mathrm{~mol} \% \mathrm{L9}, 5$ equiv $\mathrm{H}_{2} \mathrm{O}, 60{ }^{\circ} \mathrm{C}, 24 \mathrm{~h}, \mathrm{DCE}$. 
Table 30: Recyclisation of the polystyrene-supported Pd complex PdL11 [57].

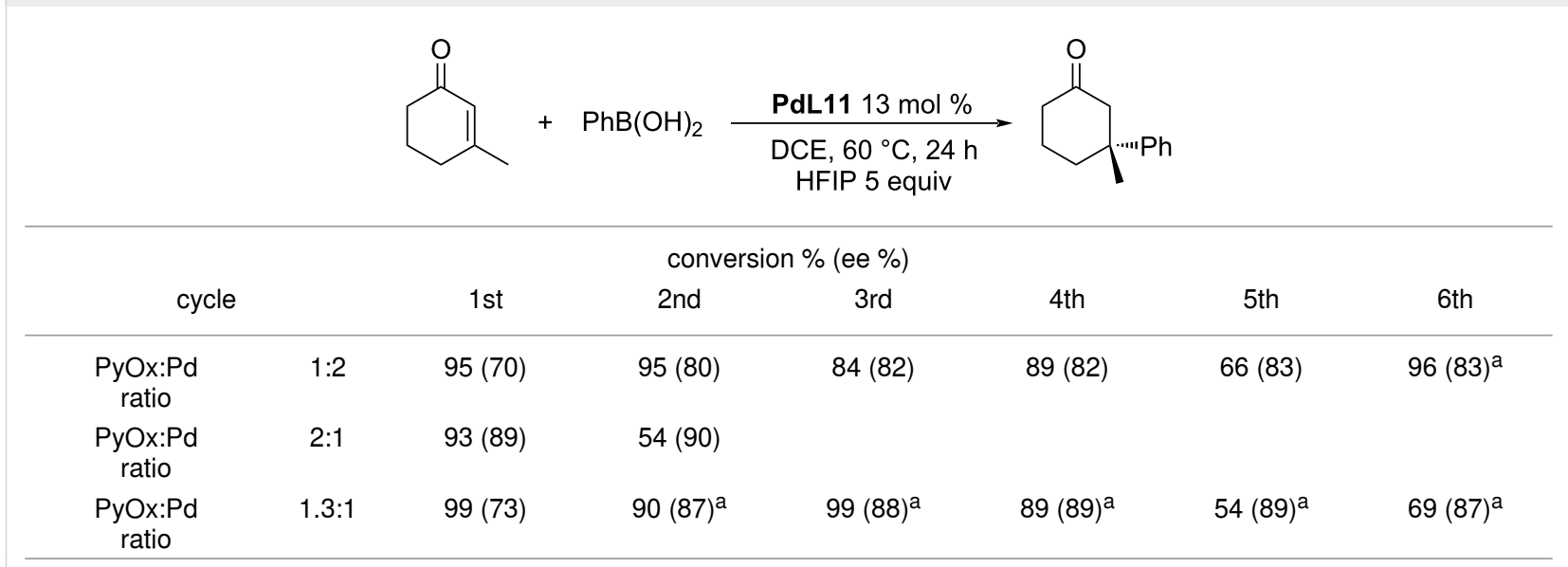

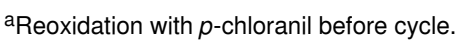

tion reaction, in this case, led to a polymeric backbone with terminal catalytic centres [58] (Scheme 20). The results obtained were consistent with those reported by O'Reilly using a polymeric backbone with catalytic centres inside the chain [56].

The authors outlined the possibility of recycling the catalyst based on the lower critical solution temperature (LCST) of the catalytic polymer system. The catalyst precipitated and was recovered by centrifugation and discarding the supernatant liquid. This process was complicated by a low catalyst loading and high phase-transition temperature leading to the loss of mass during this procedure. The authors, however, did not try the preparation of a polymer with a lower phase-transition temperature. The loss of mass was compensated by the addition of $10 \%$ of fresh catalyst. By this method, they were able to reuse the catalyst in 6 cycles with only a very small decrease in the yield $(98,>97,>97,>96,>95,>91 \%)$. Unfortunately, the enantioselectivity was not estimated after each cycle [58].

In 2019, Lee et al. focused on the enantioselective desymmetrisation of polycyclic cyclohexenediones [59]. The variously substituted pyridine-oxazolines L9 and L12a,b were tested as ligands in combination with $\mathrm{Pd}(\mathrm{OAc})_{2}$ or Pd(TFA) $)_{2}$ (Table 31 ). As a suitable solvent was chosen DMF, although the use of polar aprotic solvents usually leads to products of the oxidative Heck reaction. The authors noticed a significant reduction of $\mathrm{Pd}(\mathrm{II})$ to $\mathrm{Pd}(0)$ (by secondary processes such as oxidative homocoupling or oxidation of boronic acid to the corresponding phenol). The $\operatorname{Pd}(0)$ reduced in this way was reoxidized to Pd(II) by adding oxygen to the reaction mixture. Excellent enantiomeric excesses were observed (80-96\% ee), but the conversions were low (13-83\%), especially for boronic acids with electron-acceptor substituents (Table 31). The authors also proposed a plausible catalytic cycle as outlined in Scheme 21 [59].

The latest ligand derived from pyridine-oxazolines is $\beta$-carbolino-oxazoline, whose Pd(II) complex was studied mainly as a catalyst for the addition of arylboronic acids to nitrostyrenes. It also showed to be a highly active catalyst for the addition to enones, under conditions similar to those developed by Stoltz et al. for pyridine-oxazolines (Table 32) [60].

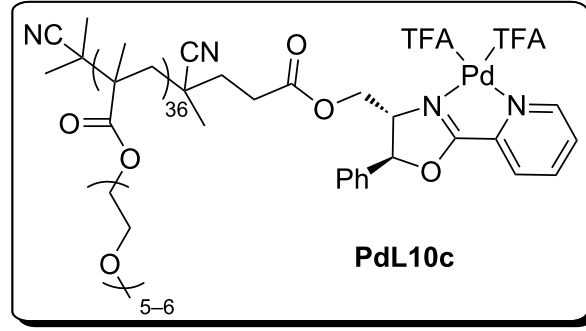<smiles></smiles><smiles>O=C1CC(c2ccccc2)Oc2ccccc21</smiles>

$(98 \% ; 82 \%$ ee) 
Table 31: Addition reactions of various boronic acids to polycyclic cyclohexenediones [59].
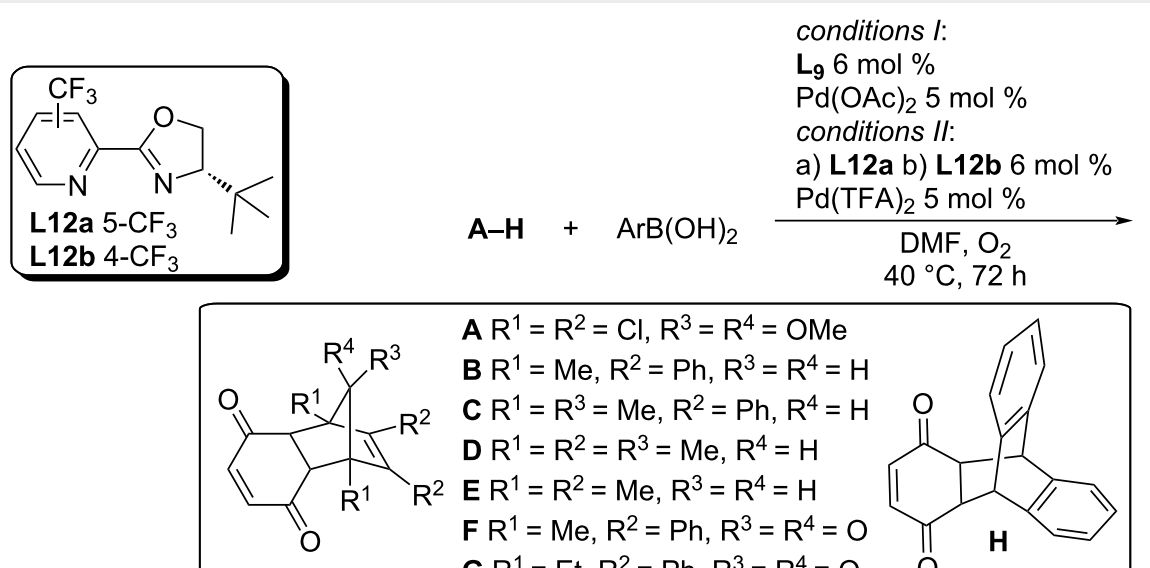
$A \mathrm{R}^{1}=\mathrm{R}^{2}=\mathrm{Cl}, \mathrm{R}^{3}=\mathrm{R}^{4}=\mathrm{OMe}$
$B R^{1}=M e, R^{2}=P h, R^{3}=R^{4}=H$
$C R^{1}=R^{3}=M e, R^{2}=P h, R^{4}=H$
$D R^{1}=R^{2}=R^{3}=M e, R^{4}=H$
$E R^{1}=R^{2}=M e, R^{3}=R^{4}=H$
$F R^{1}=M e, R^{2}=P h, R^{3}=R^{4}=0$
$\mathbf{G ~ R}^{1}=E t, R^{2}=P h, R^{3}=R^{4}=0$
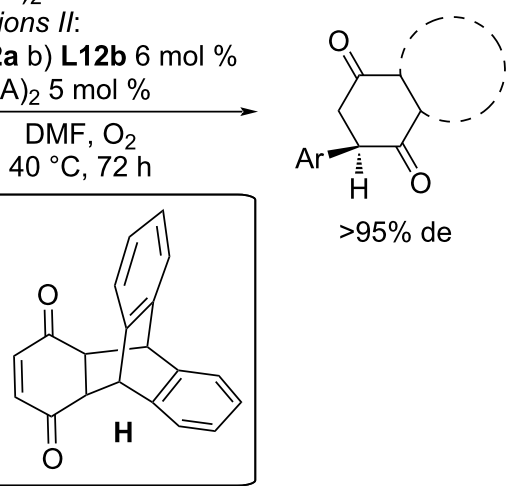

$>95 \%$ de

\begin{tabular}{|c|c|c|c|c|c|}
\hline entry & conditions & substrate & $\mathrm{Ar}$ & yield (\%) & ee $(\%)$ \\
\hline 1 & I & A & $4-\mathrm{MeO}-\mathrm{C}_{6} \mathrm{H}_{4}$ & $80^{\mathrm{a}}$ & 84 \\
\hline 2 & I & A & $4-\mathrm{HO}-\mathrm{C}_{6} \mathrm{H}_{4}$ & 65 & 80 \\
\hline 3 & 1 & B & 4- $\mathrm{MeO}-\mathrm{C}_{6} \mathrm{H}_{4}$ & 70 & 94 \\
\hline 4 & I & B & $3-\mathrm{MeO}-\mathrm{C}_{6} \mathrm{H}_{4}$ & 58 & 94 \\
\hline 5 & I & B & $2-\mathrm{MeO}-\mathrm{C}_{6} \mathrm{H}_{4}$ & $46^{\mathrm{b}}$ & 84 \\
\hline 6 & I & B & $4-\mathrm{HO}-\mathrm{C}_{6} \mathrm{H}_{4}$ & 65 & 96 \\
\hline 7 & I & B & $\mathrm{Ph}$ & $83^{b}$ & 94 \\
\hline 8 & I & B & 4-Me- $\mathrm{C}_{6} \mathrm{H}_{4}$ & $81^{\mathrm{b}}$ & 94 \\
\hline 9 & I & B & 3-Cl-4-MeO- $\mathrm{C}_{6} \mathrm{H}_{4}$ & $51^{\mathrm{b}}$ & 94 \\
\hline 10 & I & B & $4-\mathrm{F}-\mathrm{C}_{6} \mathrm{H}_{4}$ & $57^{b}(80)^{c}$ & 88 \\
\hline 11 & I & B & 4-( $\mathrm{AcNH})-\mathrm{C}_{6} \mathrm{H}_{4}$ & $42^{b, d}(60)^{c}$ & 96 \\
\hline 12 & I & B & 4-EtOOC- $\mathrm{C}_{6} \mathrm{H}_{4}$ & $13^{\mathrm{e}}$ & 90 \\
\hline 13 & 1 & C & $4-\mathrm{MeO}-\mathrm{C}_{6} \mathrm{H}_{4}$ & $73^{b}$ & 86 \\
\hline 14 & $11 a$ & D & 4-MeO- $\mathrm{C}_{6} \mathrm{H}_{4}$ & 64 & 90 \\
\hline 15 & 1 & E & 4- $\mathrm{MeO}-\mathrm{C}_{6} \mathrm{H}_{4}$ & $43^{b}$ & 94 \\
\hline 16 & Ila & E & 4- $\mathrm{MeO}-\mathrm{C}_{6} \mathrm{H}_{4}$ & 68 & 90 \\
\hline 17 & 1 & $\mathbf{F}$ & 4-MeO- $\mathrm{C}_{6} \mathrm{H}_{4}$ & 68 & 88 \\
\hline 18 & 1 & $\mathbf{G}$ & 4-MeO- $\mathrm{C}_{6} \mathrm{H}_{4}$ & $72(60)^{f}$ & $84(86)^{t}$ \\
\hline 19 & 116 & $\mathbf{H}$ & $4-\mathrm{HO}-\mathrm{C}_{6} \mathrm{H}_{4}$ & 65 & 70 \\
\hline
\end{tabular}

aTemperature $30{ }^{\circ} \mathrm{C}$; b $\mathrm{L} 911 \mathrm{~mol} \%$ and $\mathrm{Pd}\left(\mathrm{OAc}_{2}\right) 10 \mathrm{~mol} \%$; cNMR yield; $\mathrm{d}^{\mathrm{C}}$ time $92 \mathrm{~h}$; e temperature $50{ }^{\circ} \mathrm{C}$ and double amount of catalyst $(50 \%$ added at the beginning, $50 \%$ added after $24 \mathrm{~h}) ;{ }^{\mathrm{f}} 10 \times$ larger amount $(1 \mathrm{mmol})$.

\section{Catalytic systems based on bisoxazoline ligands}

In 2012, the Minnaard group followed up their pioneering work with the phosphine ligand $\mathbf{L} 2$ to expand the substrate scope to 3-substituted enones [14]. At first, they have tried their original catalytic system L2/Pd(TFA) 2 for the addition of phenylboronic acid to 3-methyl-2-cyclohexenone (Scheme 22) that provided the product with an excellent enantioselectivity of $96 \%$ but in a very poor yield $<5 \%$.

The previously used ligand was changed to bisoxazoline L14. At first, they tested in situ-generated complexes of $\mathbf{L 1 4}$ and
$\mathrm{Pd}(\mathrm{TFA})_{2}$ in methanol or acetone, but the reduction to catalytically inactive $\operatorname{Pd}(0)$ occurred faster. The reoxidation by $\mathrm{Cu}\left(\mathrm{BF}_{4}\right)_{2} \cdot 6 \mathrm{H}_{2} \mathrm{O}$ led to the loss of enantioselectivity presumably because of the complexation of the bisoxazoline by $\mathrm{Cu}$ (II). This problem could be solved by using a higher amount of the ligand (27 mol \%) [14].

The second more favourable solution was the preparation of the bisoxazoline complex with $\mathrm{PdCl}_{2}$ followed by dehalogenation. The use of $\mathrm{AgSbF}_{6}$ as the dehalogenating agent allowed the complete conversion in the model reaction with a high ee of $96 \%$ (entry 3 , Table 33). Also the addition reactions to five and 


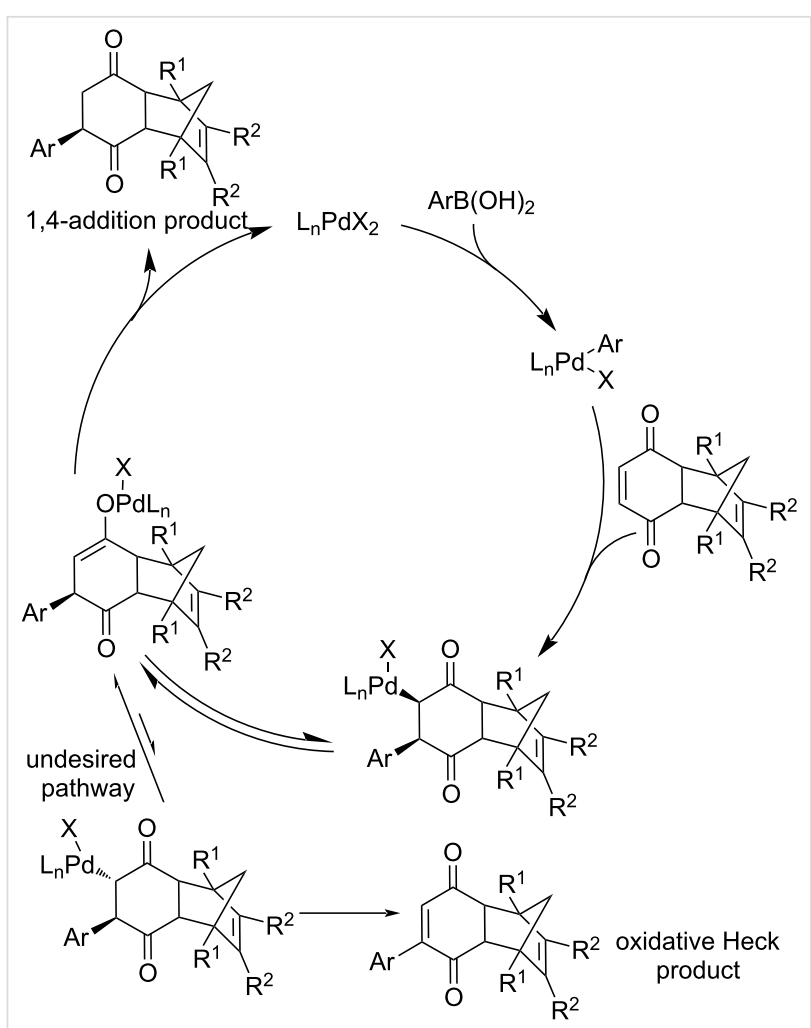

Scheme 21: Plausible catalytic cycle for the desymmetrisation of polycyclic cyclohexenediones by the addition of arylboronic acids [59].

six-membered 3-substituted enones proceeded smoothly in most cases (entries 1-11, Table 33), providing the products with remarkable enantioselectivities. The only exceptions were ortho-substituted arylboronic acids, which did not react at all (entries 12 and 13, Table 33) [14].

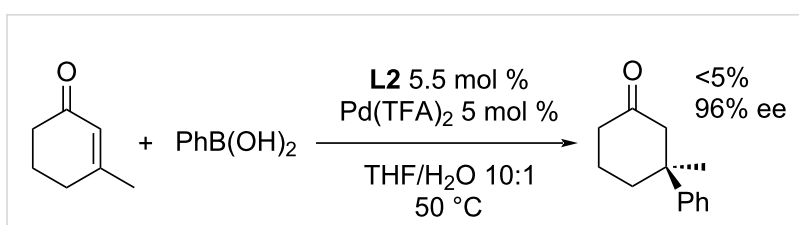

Scheme 22: Attempt to use the catalytic system L2/Pd(TFA) $)_{2}$ for the addition of phenylboronic acid to 3-methyl-2-cyclohexenone [14].

A substituent on the enone in position 3 significantly affected the reactivity (entries 3, 15, and 16, Table 33). In the case of dihydropyranone derivatives (entries 17 and 18, Table 33), the reactivity depended on the position of the oxygen in the ring. The tight geminal arrangement of oxygen with the reaction centre reduced the reactivity and enantioselectivity more than in the more distant arrangements. The substrate scope was expanded to 3-substituted linear enones, but the yields were only poor to good (up to $84 \%$ ) and the enantioselectivities were low to moderate (up to $60 \%$ ee; Table 34 ) [14].

Another option to obtain the linear product is the ring opening of the addition product of the arylboronic acid to the dihydropyran-2-one derivative (Scheme 23) [14].

The Minnaard group next focused on the increase of the reactivity of ortho-substituted boronic acids [14,15]. An optimisation study showed that the presence of AgTFA (dehalogenation reagent) and $\mathrm{NH}_{4} \mathrm{PF}_{6}(\mathrm{Pd}(\mathrm{II})$ stabilizing salt) in the reaction mixture was necessary. Additionally, the solvent was changed from a methanol/water mixture to a DCE/water biphasic system. It was also necessary to use a high excess of the starting

Table 32: Addition reactions of arylboronic acids to 3-methyl-2-cyclohexenone catalysed by $L 13 / \operatorname{Pd}(\operatorname{TFA})_{2}[60]$.
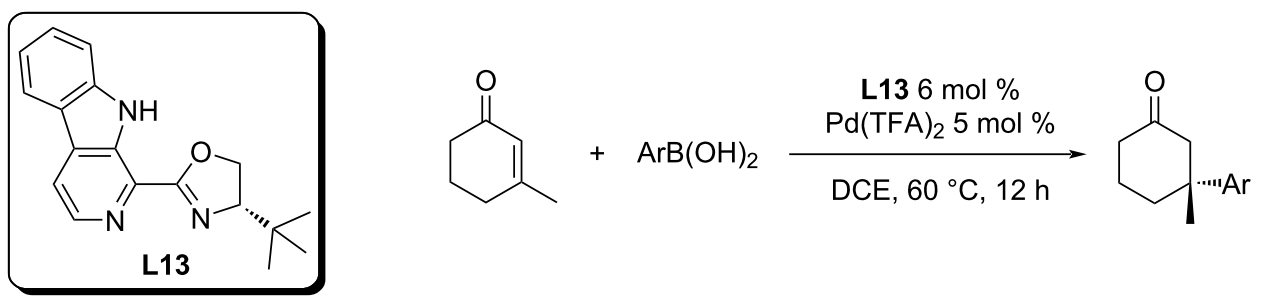

\begin{tabular}{|c|c|c|c|}
\hline entry & $\mathrm{Ar}$ & yield (\%) & ee $(\%)$ \\
\hline 1 & $\mathrm{Ph}$ & 88 & 95 \\
\hline 2 & $4-\mathrm{MeO}-\mathrm{C}_{6} \mathrm{H}_{4}$ & 75 & 70 \\
\hline 3 & $4-\mathrm{Me}-\mathrm{C}_{6} \mathrm{H}_{4}$ & 72 & 91 \\
\hline 4 & 1-naphthyl & 88 & 89 \\
\hline 5 & $4-\mathrm{CF}_{3}-\mathrm{C}_{6} \mathrm{H}_{4}$ & 86 & 96 \\
\hline 6 & $4-\mathrm{F}-\mathrm{C}_{6} \mathrm{H}_{4}$ & 81 & 95 \\
\hline 7 & $3-\mathrm{Me}-\mathrm{C}_{6} \mathrm{H}_{4}$ & 73 & 88 \\
\hline 8 & $3-\mathrm{Cl}-\mathrm{C}_{6} \mathrm{H}_{4}$ & 88 & 99 \\
\hline
\end{tabular}


Table 33: Addition reactions of arylboronic acids to various enones catalysed by palladium bisoxazoline complex PdL14 [14].

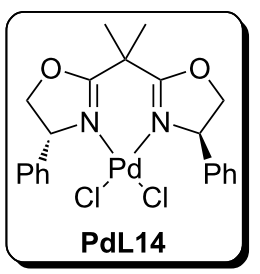<smiles>CC1=CC(=O)CCC1</smiles><smiles>[R]C1=CC(=O)CCC1</smiles><smiles>CC1=CC(=O)CCO1</smiles>

A $n=0 \quad$ D R $=\mathrm{Et}$

B $n=1 \quad \mathrm{ER}=\mathrm{Ph}$

$F$<smiles>O=C1C=CC2COCCC2=C1</smiles>

G

PdL14 $8 \mathrm{~mol} \%$ $\mathrm{AgSbF}_{6} 20 \mathrm{~mol} \%$

C $n=2$

\begin{tabular}{|c|c|c|c|c|}
\hline entry & substrate & $\mathrm{Ar}$ & yield $(\%)$ & ee $(\%)$ \\
\hline 1 & A & $\mathrm{Ph}$ & 93 & 93 \\
\hline 2 & A & 4-Me- $\mathrm{C}_{6} \mathrm{H}_{4}$ & 68 & 90 \\
\hline 3 & B & $\mathrm{Ph}$ & 100 & 96 \\
\hline 4 & B & $3-\mathrm{Me}-\mathrm{C}_{6} \mathrm{H}_{4}$ & 89 & 97 \\
\hline 5 & B & 4-Me- $\mathrm{C}_{6} \mathrm{H}_{4}$ & 96 & 97 \\
\hline 6 & B & $4-\mathrm{F}-\mathrm{C}_{6} \mathrm{H}_{4}$ & 88 & 98 \\
\hline 7 & B & $3-\mathrm{EtO}^{-\mathrm{C}_{6}} \mathrm{H}_{4}$ & 44 & 93 \\
\hline 8 & B & $3-\mathrm{Cl}-\mathrm{C}_{6} \mathrm{H}_{4}$ & $30^{\mathrm{a}}$ & 98 \\
\hline 9 & B & $3-\mathrm{Cl}-4-\mathrm{MeO}-\mathrm{C}_{6} \mathrm{H}_{3}$ & 98 & $>99$ \\
\hline 10 & B & 4- $\mathrm{MeO}-\mathrm{C}_{6} \mathrm{H}_{4}$ & 85 & 98 \\
\hline 11 & B & $3,4-\left(\mathrm{CH}_{2} \mathrm{O}_{2}\right)-\mathrm{C}_{6} \mathrm{H}_{3}$ & 98 & 96 \\
\hline 12 & B & 2-Me- $\mathrm{C}_{6} \mathrm{H}_{4}$ & 0 & - \\
\hline 13 & B & ferrocenyl & 0 & - \\
\hline 14 & C & $\mathrm{Ph}$ & 80 & 94 \\
\hline 15 & D & $\mathrm{Ph}$ & 91 & 99 \\
\hline 16 & $\mathbf{E}$ & $\mathrm{Ph}$ & 0 & - \\
\hline 17 & $\mathbf{F}$ & $\mathrm{Ph}$ & 28 & 69 \\
\hline 18 & G & $\mathrm{Ph}$ & 57 & 88 \\
\hline
\end{tabular}

${ }^{\mathrm{a}} 60^{\circ} \mathrm{C}$.

Table 34: Addition reactions of arylboronic acids to linear enones catalysed by the bisoxazoline complex PdL14 [14].

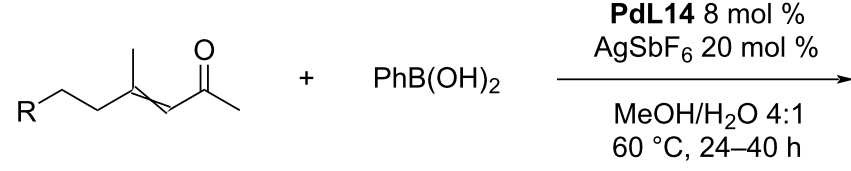

$60{ }^{\circ} \mathrm{C}, 24-40 \mathrm{~h}$
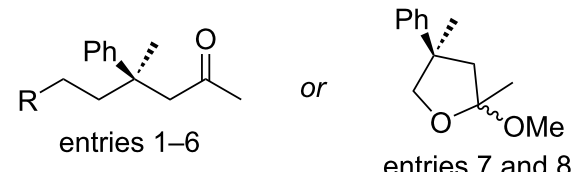

\begin{tabular}{ccccc}
\hline entry & substrate configuration & $\mathrm{R}$ & yield (\%) & ee (\%) \\
\hline 1 & $E$ & $\mathrm{Ph}$ & 14 & 8 \\
2 & $E$ & $t$-Bu & $<10$ & - \\
3 & $E$ & $t$-BuO & 84 & 23 \\
4 & $\mathrm{BnO}$ & 81 & 25 \\
5 & $\mathrm{BnO}$ & 78 & 36 \\
6 & $\mathrm{~B}$ & TBDPSO & 38 & 60 \\
7 & $E$ & TrO & 53 & $51^{\mathrm{a}}$ \\
\hline
\end{tabular}

aDetermined after ring opening of the ketal. 
<smiles>C[C@]1(c2ccccc2)CCOC(=O)C1</smiles>

$88 \%$ ee

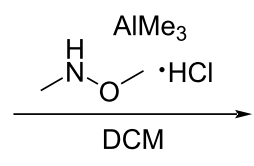

$91 \%$
$\mathrm{HO}_{\mathrm{I}} \mathrm{N}^{-} \mathrm{O}_{-}$

Scheme 23: Ring opening of an enantioenriched tetrahydropyran-2one derivative as alternative strategy to linear products [14].

enone ( 7 equiv). The results are summarised in Table 35 and it is clear that the yields for most of the cases were very low and exceeded $30 \%$ in only a few cases (mostly when a high catalyst amount was used). On the other hand, the enantioselectivities were excellent in almost every example (Table 35) [14,15].

Selected addition products were used as intermediates in the total syntheses of various biologically active compounds (Scheme 24) [14-16].

\section{Catalytic systems based on different groups of ligands}

The use of the chiral 1,10-phenanthroline ligand $\mathbf{L} 15$ for the addition of phenylboronic acid to 2-cyclohexenone and chromone (Scheme 25) [61] was proposed by Tamura et al. in 2017. Excellent conversions and enantioselectivities (96-97\%; 94-97\% ee) were achieved for both studied substrates. However, a further use of this ligand has not been published yet.

Optically pure pyridine-hydrazones were successfully used for a number of various enantioselective transformations [62]. In 2019, Retamosa et al. used them for 1,4- and 1,6-addition reactions of boronic acids to cyclic (di)enones. Initial studies showed the best yields when DCE was used as a solvent upon the addition of 0.2 equiv of water [62]. Without the addition of water, no reproducible results were obtained. The addition of 1.1-1.5 equiv of water caused a minimal decrease of the enan-

Table 35: Addition reactions of ortho-substituted arylboronic acids to five and six-membered enones [14,15].

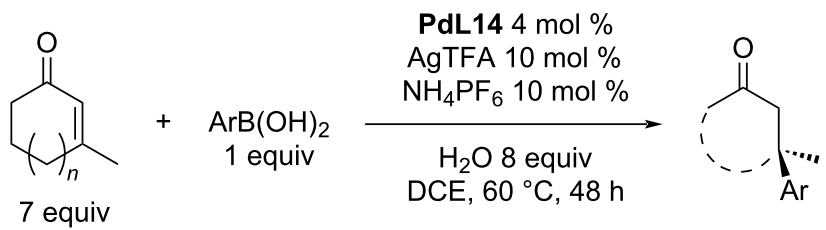

\begin{tabular}{|c|c|c|c|c|}
\hline entry & $n$ & $\operatorname{Ar}$ & yield (\%) & ee $(\%)$ \\
\hline 1 & 0 & $2-\mathrm{Me}-\mathrm{C}_{6} \mathrm{H}_{4}$ & 23 & 90 \\
\hline 2 & 1 & $2-\mathrm{Me}-\mathrm{C}_{6} \mathrm{H}_{4}$ & 16 & 98 \\
\hline 3 & 0 & $2-\mathrm{MeO}-\mathrm{C}_{6} \mathrm{H}_{4}$ & 45 & 80 \\
\hline 4 & 1 & $2-\mathrm{MeO}-\mathrm{C}_{6} \mathrm{H}_{4}$ & $42^{a}$ & 96 \\
\hline 5 & 0 & $2-\mathrm{F}-\mathrm{C}_{6} \mathrm{H}_{4}$ & 20 & 95 \\
\hline 6 & 1 & $2-\mathrm{F}-\mathrm{C}_{6} \mathrm{H}_{4}$ & $23^{a}$ & 95 \\
\hline 7 & 0 & $2-\mathrm{Cl}-\mathrm{C}_{6} \mathrm{H}_{4}$ & $12^{\mathrm{a}}$ & 94 \\
\hline 8 & 1 & $2-\mathrm{Cl}-\mathrm{C}_{6} \mathrm{H}_{4}$ & $<10$ & - \\
\hline 9 & 0 & dibenzofuran-4-yl & 51 & 94 \\
\hline 10 & 1 & dibenzofuran-4-yl & 36 & 94 \\
\hline 11 & 0 & 1-naphthyl & $38^{a}$ & 85 \\
\hline 12 & 1 & 1-naphthyl & 26 & 95 \\
\hline 13 & 0 & 2,3-diOMe-5-Me- $\mathrm{C}_{6} \mathrm{H}_{2}$ & $55^{a}$ & 92 \\
\hline 14 & 1 & 2,3-diOMe-5-Me- $\mathrm{C}_{6} \mathrm{H}_{2}$ & 19 & 94 \\
\hline 15 & 0 & 2,3-diMeO- $\mathrm{C}_{6} \mathrm{H}_{3}$ & 25 & 94 \\
\hline 16 & 1 & 2,3-diMeO- $\mathrm{C}_{6} \mathrm{H}_{3}$ & 44 & 99 \\
\hline 17 & 0 & 2-MeO-5-Me- $\mathrm{C}_{6} \mathrm{H}_{3}$ & $32^{a}$ & 80 \\
\hline 18 & 1 & 2-MeO-5-Me- $\mathrm{C}_{6} \mathrm{H}_{3}$ & 28 & 91 \\
\hline 19 & 0 & 2,5-diMeO-4-Me- $\mathrm{C}_{6} \mathrm{H}_{2}$ & $21^{a}$ & 74 \\
\hline 20 & 1 & 2,5-diMeO-4-Me- $\mathrm{C}_{6} \mathrm{H}_{2}$ & $<10$ & 84 \\
\hline 21 & 0 & 2-MeO-4-Me- $\mathrm{C}_{6} \mathrm{H}_{3}$ & $<10$ & 68 \\
\hline 22 & 1 & 2-MeO-4-Me- $\mathrm{C}_{6} \mathrm{H}_{3}$ & 17 & 90 \\
\hline
\end{tabular}

*8 mol \% PdL14 used. 

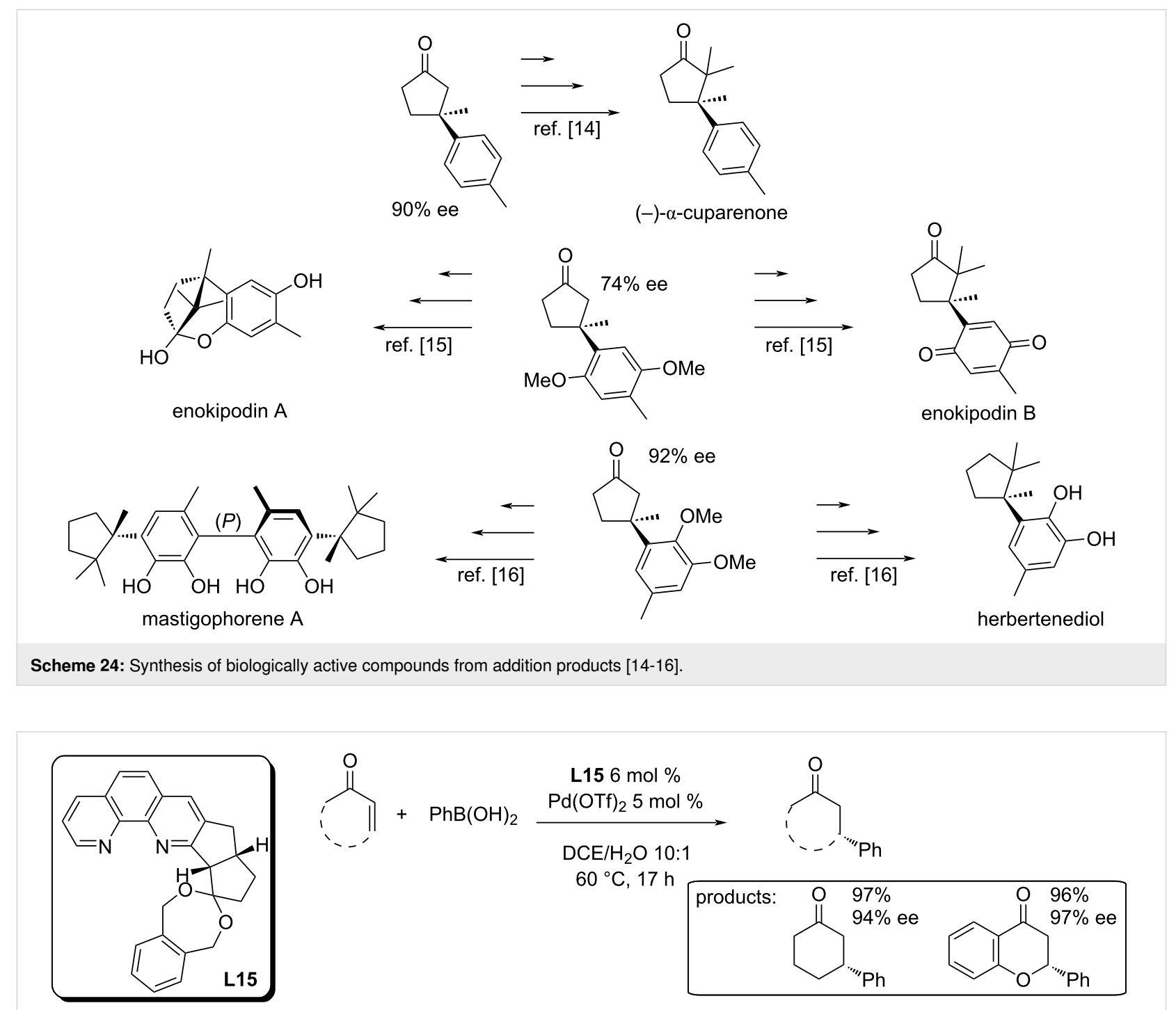

Scheme 25: Chiral 1,10-phenantroline derivative L15 as ligand for the Pd-catalysed addition reactions of phenylboronic acid to 2-cyclohexenone and chromone [61].

tioselectivity from 91 to $88 \%$ ee (entries 1 and 2, Table 36) [62].

For the whole series of different substrates and boronic acids, there were enantioselectivities of about $90 \%$ ee and average to excellent yields of $43-97 \%$ (Table 36) [62]. This catalytic system worked for 3-unsubstituted enones but was much more powerful in the case of addition reactions to 3-substituted enones that lead to all-carbon quaternary stereogenic centres [62].

In the case of 1,6-additions, the amount of the starting dienones was increased to 4.17 equivalents relative to the boronic acids. Further, the boronic acid was gradually added over 12 hours and then the mixture was kept under the reaction conditions for another time period up to total 72 or $96 \mathrm{~h}$. The prolonged reaction time increased the obtained yields but at the expense of reducing the enantioselectivity of the product ( 61 to $81 \% ; 79$ to $67 \%$ ee; entries 1 and 2, Table 37). This led to the conclusion that the ligand is not chemically stable in the reaction medium and undergoes decomposition over time. Only low to average conversions (up to $81 \%$ ) and only average enantioselectivities (up to $80 \%$ ee; Table 37 ) were achieved for the studied substrates [62].

One of the most recent contributions to this topic came from the group of Hong and Stoltz in 2020. Here, attention was focused on the development of a methodology for the enantioselective addition to 2-substituted chromones [63]. The original work from the Stoltz group using pyridine-oxazolines was very suc- 
Table 36: Addition reactions of arylboronic acids to five and six-membered enones catalysed by L16/Pd(TFA) 2 [62]
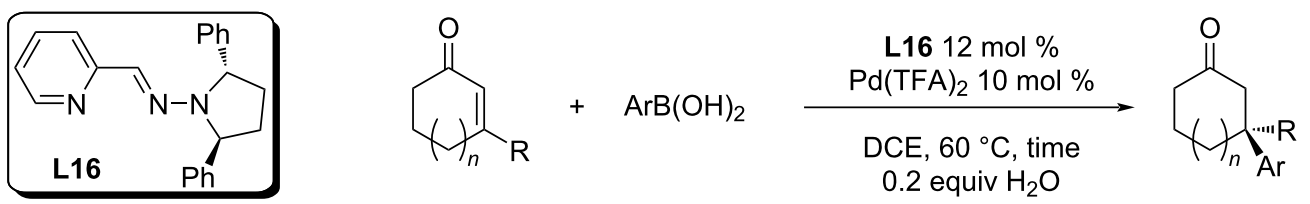

\begin{tabular}{|c|c|c|c|c|c|c|}
\hline entry & $n$ & $\mathrm{R}$ & $\mathrm{Ar}$ & time $(\mathrm{h})$ & yield (\%) & ee $(\%)$ \\
\hline 1 & 1 & $\mathrm{Me}$ & $\mathrm{Ph}$ & 24 & 94 & 91 \\
\hline 2 & 1 & $\mathrm{Me}$ & $\mathrm{Ph}$ & 24 & $90^{\mathrm{a}}$ & $88^{a}$ \\
\hline 3 & 1 & $\mathrm{Me}$ & 4-Me- $\mathrm{C}_{6} \mathrm{H}_{4}$ & 48 & 93 & 91 \\
\hline 4 & 1 & $\mathrm{Me}$ & $4-\mathrm{F}-\mathrm{C}_{6} \mathrm{H}_{4}$ & 72 & 43 & 90 \\
\hline 5 & 1 & $\mathrm{Me}$ & $4-\mathrm{Cl}-\mathrm{C}_{6} \mathrm{H}_{4}$ & 72 & 77 & 90 \\
\hline 6 & 1 & $\mathrm{Me}$ & $4-\mathrm{MeO}-\mathrm{C}_{6} \mathrm{H}_{4}$ & 72 & 73 & 90 \\
\hline 7 & 1 & $\mathrm{Me}$ & $4-\mathrm{CF}_{3} \mathrm{O}-\mathrm{C}_{6} \mathrm{H}_{4}$ & 72 & 65 & 90 \\
\hline 8 & 1 & $\mathrm{Me}$ & 3,5-diMe- $\mathrm{C}_{6} \mathrm{H}_{3}$ & 24 & 75 & 92 \\
\hline 9 & 1 & Et & $\mathrm{Ph}$ & 48 & 80 & 89 \\
\hline 10 & 1 & $\mathrm{Ph}$ & 4-MeO- $\mathrm{C}_{6} \mathrm{H}_{4}$ & 72 & 0 & - \\
\hline 11 & 1 & $\mathrm{H}$ & $\mathrm{Ph}$ & 48 & 76 & 87 \\
\hline 12 & 0 & $\mathrm{Me}$ & $\mathrm{Ph}$ & 20 & 95 & 88 \\
\hline 13 & 0 & $\mathrm{Me}$ & 2-MeO- $\mathrm{C}_{6} \mathrm{H}_{4}$ & 48 & 73 & 91 \\
\hline 14 & 0 & $\mathrm{Me}$ & $4-\mathrm{Me}^{-} \mathrm{C}_{6} \mathrm{H}_{4}$ & 48 & 97 & 88 \\
\hline 15 & 0 & $\mathrm{Me}$ & 3,4- $\left(\mathrm{CH}_{2} \mathrm{O}_{2}\right) \mathrm{C}_{6} \mathrm{H}_{3}$ & 60 & $65^{b}$ & $86^{\mathrm{b}}$ \\
\hline 16 & 0 & $\mathrm{Me}$ & 2,5-diOMe-4-MeC ${ }_{6} \mathrm{H}_{2}$ & 72 & 38 & 93 \\
\hline
\end{tabular}

a1.1 equiv of water used; b ${ }^{2} 169 \mathrm{~mol} \%$ and Pd(TFA) $27.5 \mathrm{~mol} \%$ were used.

Table 37: 1,6-Addition reaction of arylboronic acids to dienones catalysed by $\operatorname{L16/Pd(TFA)} 2$ [62].<smiles>[R]C=CC1=CC(=O)CCC1</smiles>

4.17 equiv
$+\operatorname{ArB}(\mathrm{OH})_{2}$

1 equiv
L16 $17 \mathrm{~mol} \%$<smiles>[R]C(Br)CC1CCC(C(=O)O)C(=O)C1</smiles>
$\mathrm{H}_{2} \mathrm{O} 0.2$ equiv

\begin{tabular}{|c|c|c|c|c|c|}
\hline entry & $\mathrm{R}$ & $\mathrm{Ar}$ & time (h) & yield (\%) & ee (\%) \\
\hline 1 & $\mathrm{Me}$ & $\mathrm{Ph}$ & 72 & 61 & 79 \\
\hline 2 & $\mathrm{Me}$ & $\mathrm{Ph}$ & 96 & 81 & 67 \\
\hline 3 & $\mathrm{Me}$ & 4-Me- $\mathrm{C}_{6} \mathrm{H}_{4}$ & 72 & 44 & 74 \\
\hline 4 & $\mathrm{Me}$ & 4-Me- $\mathrm{C}_{6} \mathrm{H}_{4}$ & 96 & 78 & 68 \\
\hline 5 & $\mathrm{Me}$ & $4-\mathrm{CF}_{3} \mathrm{O}-\mathrm{C}_{6} \mathrm{H}_{4}$ & 72 & 35 & 80 \\
\hline 6 & $\mathrm{Me}$ & $4-\mathrm{CF}_{3} \mathrm{O}-\mathrm{C}_{6} \mathrm{H}_{4}$ & 96 & 47 & 72 \\
\hline 7 & $n-\mathrm{Bu}$ & $\mathrm{Ph}$ & 72 & 31 & 52 \\
\hline
\end{tabular}

cessful for addition reactions to 2-unsubstituted chromones (Table 23). However, in the attempted addition reaction of phenylboronic acid to 2-methylchromone, the expected product was not isolated (entry 6, Table 22) [51]. Therefore, a new optically pure substituted pyridine-dihydroisoquinoline $\mathbf{L 1 7}$ was developed (Table 38) [63]. The studied catalytic system of ligand
$\mathbf{L 1 7}$ in combination with $\operatorname{Pd}(\mathrm{TFA})_{2}$ allowed the isolation of the desired products in excellent yields, especially for electron-rich boronic acids. The yields for the products from addition reactions with electron-poor boronic acids were only average. However, excellent enantioselectivities were achieved for all studied substrate combinations (90-99\% ee; Table 38) [63]. 
Table 38: Addition reactions of arylboronic acids to 2-substituted chromones catalysed by L17/Pd(TFA) $[$ [63].
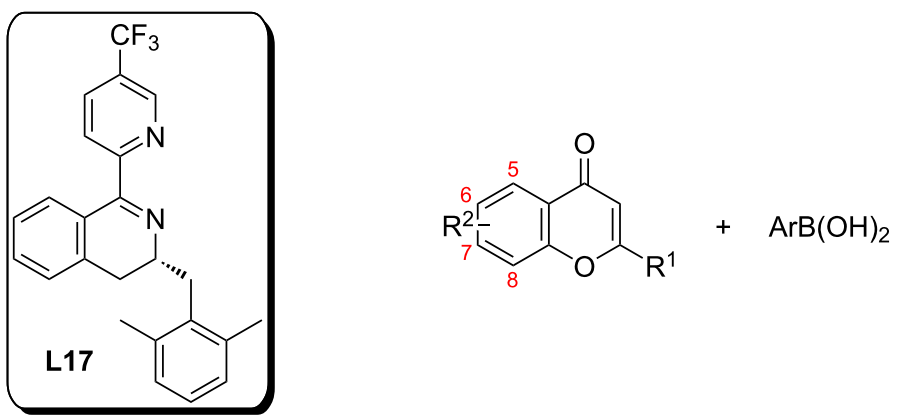

L17 $6 \mathrm{~mol} \%$ $\mathrm{Pd}(\mathrm{TFA})_{2} 5 \mathrm{~mol} \%$ $\mathrm{NH}_{4} \mathrm{PF}_{6} 30 \mathrm{~mol} \%$ water, $\mathrm{O}_{2}$

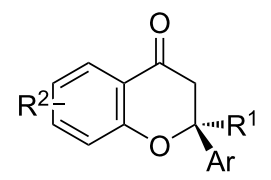

\begin{tabular}{|c|c|c|c|c|c|}
\hline entry & $\mathrm{R}^{1}$ & $\mathrm{R}^{2}$ & $\mathrm{Ar}$ & yield (\%) & ee $(\%)$ \\
\hline 1 & $\mathrm{Me}$ & $\mathrm{H}$ & $\mathrm{Ph}$ & 98 & 95 \\
\hline 2 & $\mathrm{Me}$ & $\mathrm{H}$ & $4-\mathrm{Me}-\mathrm{C}_{6} \mathrm{H}_{4}$ & 80 & 96 \\
\hline 3 & $\mathrm{Me}$ & $\mathrm{H}$ & 4-Et- ${ }_{6} \mathrm{H}_{4}$ & 85 & 98 \\
\hline 4 & $\mathrm{Me}$ & $\mathrm{H}$ & $4-\mathrm{MeO}-\mathrm{C}_{6} \mathrm{H}_{4}$ & 51 & 90 \\
\hline 5 & $\mathrm{Me}$ & $\mathrm{H}$ & $4-t-\mathrm{Bu}-\mathrm{C}_{6} \mathrm{H}_{4}$ & 78 & 98 \\
\hline 6 & $\mathrm{Me}$ & $\mathrm{H}$ & $3-\mathrm{MeO}-\mathrm{C}_{6} \mathrm{H}_{4}$ & 81 & 99 \\
\hline 7 & $\mathrm{Me}$ & $\mathrm{H}$ & $3-\mathrm{Me}-\mathrm{C}_{6} \mathrm{H}_{4}$ & 82 & 99 \\
\hline 8 & $\mathrm{Me}$ & $\mathrm{H}$ & 3,5-diMe- $\mathrm{C}_{6} \mathrm{H}_{3}$ & 77 & 97 \\
\hline 9 & $\mathrm{Me}$ & $\mathrm{H}$ & $3,4-\left(\mathrm{CH}_{2} \mathrm{O}_{2}\right)-\mathrm{C}_{6} \mathrm{H}_{3}$ & 47 & 96 \\
\hline 10 & $\mathrm{Me}$ & $\mathrm{H}$ & $4-\mathrm{F}-\mathrm{C}_{6} \mathrm{H}_{4}$ & 80 & 98 \\
\hline 11 & $\mathrm{Me}$ & $\mathrm{H}$ & $4-\mathrm{Cl}-\mathrm{C}_{6} \mathrm{H}_{4}$ & 86 & 99 \\
\hline 12 & Me & $\mathrm{H}$ & $4-\mathrm{Br}-\mathrm{C}_{6} \mathrm{H}_{4}$ & 32 & 98 \\
\hline 13 & Me & $\mathrm{H}$ & $4-\mathrm{CF}_{3}-\mathrm{C}_{6} \mathrm{H}_{4}$ & 31 & 99 \\
\hline 14 & $\mathrm{Me}$ & $\mathrm{H}$ & $3-\mathrm{F}-\mathrm{C}_{6} \mathrm{H}_{4}$ & 60 & 96 \\
\hline 15 & $\mathrm{Me}$ & $\mathrm{H}$ & $3-\mathrm{Cl}-\mathrm{C}_{6} \mathrm{H}_{4}$ & 55 & 92 \\
\hline 16 & Et & $\mathrm{H}$ & $\mathrm{Ph}$ & 93 & 98 \\
\hline 17 & $\mathrm{iPr}$ & $\mathrm{H}$ & $\mathrm{Ph}$ & 47 & 97 \\
\hline 18 & Cy & $\mathrm{H}$ & $\mathrm{Ph}$ & 48 & 98 \\
\hline 19 & $\mathrm{Bn}$ & $\mathrm{H}$ & $\mathrm{Ph}$ & 52 & 98 \\
\hline 20 & $\mathrm{Me}$ & 6-Me & $\mathrm{Ph}$ & 89 & 98 \\
\hline 21 & $\mathrm{Me}$ & 6-MeO & $\mathrm{Ph}$ & 88 & 98 \\
\hline 22 & $\mathrm{Me}$ & 7-MeO & $\mathrm{Ph}$ & 92 & 98 \\
\hline 23 & $\mathrm{Me}$ & $6-\mathrm{F}$ & $\mathrm{Ph}$ & 74 & 97 \\
\hline 24 & $\mathrm{Me}$ & $6-\mathrm{Cl}$ & $\mathrm{Ph}$ & 90 & 96 \\
\hline 25 & $\mathrm{Me}$ & $6-\mathrm{Br}$ & $\mathrm{Ph}$ & 64 & 99 \\
\hline
\end{tabular}

\section{Evaluation of current state and outlook}

Asymmetric addition reactions to enones have so far been described in the literature in connection with catalysis. The catalyst is usually a complex of a transition metal with a suitable ligand. However, metal-free catalysis is also known [64]. Among the most successful transition-metal catalysts are those based on rhodium, as evidenced by the number of reports that deal with the issue. The rhodium-catalysed addition of various boronic acids to conjugated cyclic enones (the so-called Hayashi-Miyaura reaction) is a well-established method for 3-unsubstituted substrates as well as for 2-unsubstituted chromones [17-19,21-24]. On the other hand, there is only one example of the usage of a rhodium-based catalyst for the addi- tion of arylboronic acid to 3-substituted enones. The olefinooxazoline ligand $\mathbf{L 1 8}$ has been used for the rhodium-catalysed addition reaction of phenylboronic acid to 3-methyl-2-cyclohexenone and affording the product in a low yield and moderate enantioselectivity $(36 \% ; 85 \%$ ee; Scheme 26) [20]. Palladium-based catalysis provides better results in this area.

Up to now, asymmetric addition reactions to sterically hindered enones are still challenging. In Scheme 27, we present some underdeveloped methodologies.

We have so far tried to achieve asymmetric addition to some of these cyclic enones in our laboratory without success. Specifi- 

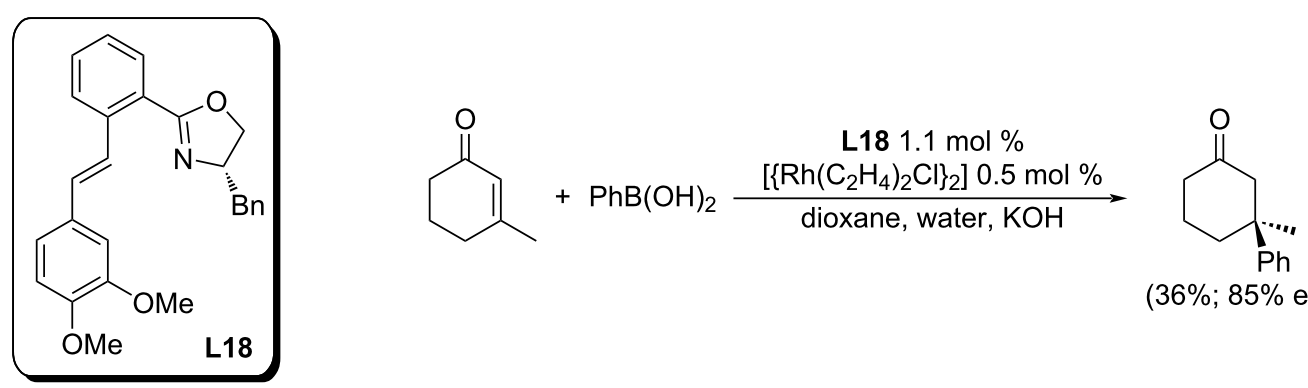

$(36 \% ; 85 \%$ ee $)$

Scheme 26: The Rh-catalysed addition reaction of phenylboronic acid to a 3-substituted enone [20].<smiles>[R][R]C([R])=CC([R])=O</smiles><smiles>[R]C1=CC(=O)CCC1([R])[R]</smiles>

$\mathrm{R}^{1} \neq \mathrm{H}$ or $\mathrm{R}^{2} \neq \mathrm{H}$<smiles>CC1=CC(=O)CC(C)(C)C1</smiles><smiles>CC1=CC(=O)CC1(C)C</smiles>

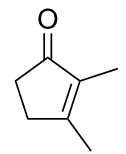

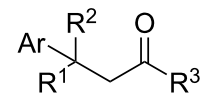

only $<60 \%$ ee<smiles>[R]C1C(=O)CC2CCCC21[Te]</smiles>
only diastereoselective

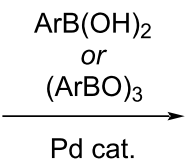

Pd cat. only diastereoselective

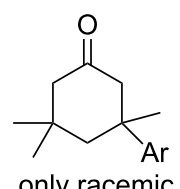

only racemic

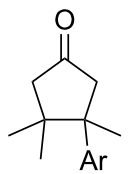

unreactive

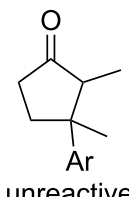

unreactive

Scheme 27: Underdeveloped methodologies [14,15,65-67]

cally, it was catalysis in a homogeneous medium, using ligand L9 and Pd (TFA) 2 . Also, continuous-flow reactions are currently a general challenge, especially for the pharmaceutical industry. The prerequisite for a successful continuous synthesis in the field of asymmetric addition reactions to enones is the mastery of recyclable heterogeneous catalysis. Very recently, we reported [57] the first heterogeneous polystyrene-supported recyclable catalyst for asymmetric conjugate addition reactions

of arylboronic acids to five and six-membered enones. In our laboratory, we also attempted to perform this reaction under flow conditions. However, the change from batch to flow arrangement itself is another challenging task. Nevertheless, it should be noted at this point that in the case of rhodium complex catalysis, the asymmetric addition of phenylboronic acid to enones in continuous flow has been successful [24]. In 2021, Walhers et al. presented a theoretical study based on the Q2MM method about the asymmetric addition of arylboronic acids to conjugated cyclic enones, catalysed by a complex of L9 and $\operatorname{Pd}(\mathrm{TFA})_{2}$ [68]. The authors prepared a training set from the data of currently known combinations of PyOx derivatives as ligands, boronic acids and enones ( 82 hits). They have calculated the predictions of enantioselectivities for $\mathrm{Pd}(\mathrm{TFA})_{2}$ complexes of 27 new PyOx-type ligands (for the reaction of 3-methyl-2-cyclohexenone with phenylboronic acid) and 59 new enones (in reactions with phenylboronic acid catalysed by L9/Pd(TFA $)_{2}$ ). The calculation performed was related to a transition state and included steric and inductive effects. Although this approach may be suitable for predicting theoretically achievable enantioselectivity and is very promising, it is not engineered to predict reactivity. Besides, the reactivity (conversion or yield) depends on the reaction medium which is not included in the theoretical model. The experimental validation of the predicted results is therefore a challenge that has to be finished [68].

\section{Conclusion}

In this review, we focused on palladium-catalysed asymmetric 1,4-addition reactions of arylboronic acids to conjugated enones and chromones. The suitability of the ligand used, the reaction conditions, and additives in terms of the yield and enantioselectivity of the transformation have been discussed. The review is classified according to the type of ligand of the catalytic complex used. The yields and corresponding enantioselectivities from the relevant literature were summarised in clear tables. Based on the above results, we propose a flowchart facilitating the reader in selecting a suitable ligand for a given combination of enone and arylboronic acid (Scheme 28). However, the 


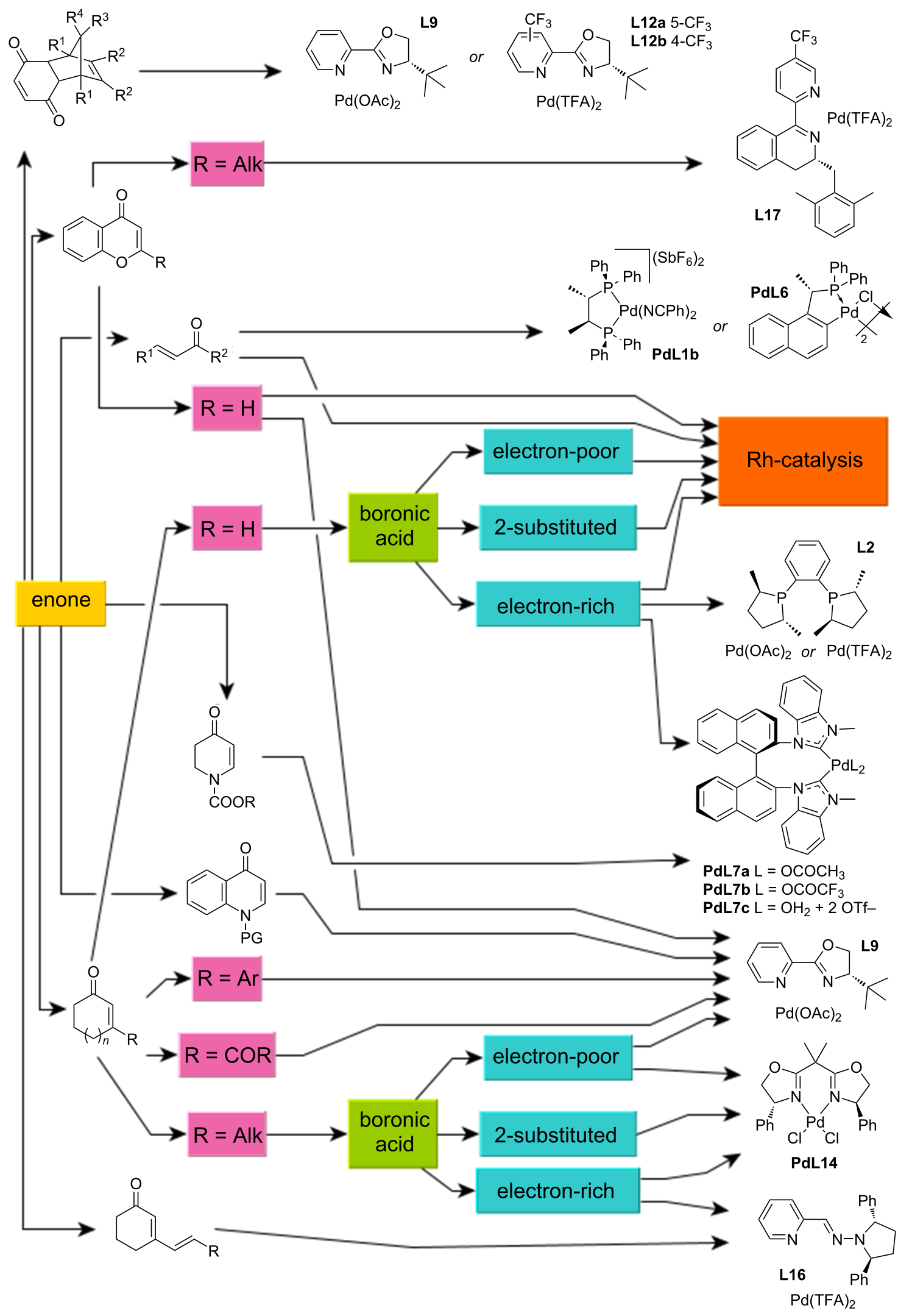


reader should be aware of its limitations because not all ligands have been studied on all substrates. Also, close to the end of the review, the catalysis by rhodium complexes has been mentioned. With these catalysts only reactions of 3-unsubstituted enone derivatives have been described. It can be said that, despite great efforts, some problems remain unresolved. Thus, palladium-based catalysts represent a more suitable alternative to the widely used rhodium complexes for these sterically hindered enone derivatives.

\section{Funding}

The authors thank the Czech Ministry of Education Youth and Sports (project number SGS_2021_004) for financial support.

\section{ORCID ${ }^{\circledR} \mathrm{iDs}$}

Jan Bartáček - https://orcid.org/0000-0001-5078-7751 Jan Svoboda - https://orcid.org/0000-0001-7948-4746 Jaroslav Pochobradský - https://orcid.org/0000-0003-3792-6408 Alexander Čegan - https://orcid.org/0000-0001-9977-8223 Miloš Sedlák - https://orcid.org/0000-0001-9112-812X Jiří Váňa - https://orcid.org/0000-0003-4756-7314

\section{References}

1. Albuquerque de Oliveira Mendes, L.; Ponciano, C. S.; Depieri Cataneo, A. H.; Wowk, P. F.; Bordignon, J.; Silva, H.; Vieira de Almeida, M.; Ávila, E. P. Chem.-Biol. Interact. 2020, 331 , 109218. doi:10.1016/j.cbi.2020.109218

2. Tutunchi, H.; Naeini, F.; Ostadrahimi, A.; Hosseinzadeh-Attar, M. J. Phytother. Res. 2020, 34, 3137-3147. doi:10.1002/ptr.6781

3. Kobayashi, K.; Nishikata, T.; Yamamoto, Y.; Miyaura, N. Bull. Chem. Soc. Jpn. 2008, 81, 1019-1025. doi:10.1246/bcsj.81.1019

4. Bürki, C.; Whyte, A.; Arndt, S.; Hashmi, A. S. K.; Lautens, M. Org. Lett. 2016, 18, 5058-5061. doi:10.1021/acs.orglett.6b02505

5. Wang, X.; Liu, B.; Searle, X.; Yeung, C.; Bogdan, A.; Greszler, S.; Singh, A.; Fan, Y.; Swensen, A. M.; Vortherms, T.; Balut, C.; Jia, Y.; Desino, K.; Gao, W.; Yong, H.; Tse, C.; Kym, P. J. Med. Chem. 2018 61, 1436-1449. doi:10.1021/acs.jmedchem.7b01339

6. Greszler, S. N.; Shelat, B.; Voight, E. A. Org. Lett. 2019,21, 5725-5727. doi:10.1021/acs.orglett.9b02099

7. Liu, X.; Pu, W.; He, H.; Fan, X.; Zheng, Y.; Zhou, J.-K.; Ma, R.; He, J.; Zheng, Y.; Wu, K.; Zhao, Y.; Yang, S.-Y.; Wang, C.; Wei, Y.-Q.; Wei, X.-W.; Peng, Y. Cancer Lett. 2019, 458, 76-85. doi:10.1016/j.canlet.2019.05.016

8. Khatua, A.; Shaw, K.; Bisai, V. Tetrahedron Lett. 2020, 61, 151736 doi:10.1016/j.tetlet.2020.151736

9. Timmerman, J. C.; Sims, N. J.; Wood, J. L. J. Am. Chem. Soc. 2019 141, 10082-10090. doi:10.1021/jacs.9b04472

10. Li, L.-Q.; Li, M.-M.; Chen, D.; Liu, H.-M.; Geng, H.-C.; Lin, J.; Qin, H.-B. Tetrahedron Lett. 2014, 55, 5960-5962. doi:10.1016/j.tetlet.2014.08.110

11. Shockley, S. E.; Holder, J. C.; Stoltz, B. M. Org. Lett. 2014, 16, 6362-6365. doi:10.1021/ol5031537

12. Shaw, K.; Niyogi, S.; Bisai, V. Tetrahedron Lett. 2020, 61, 151850. doi:10.1016/j.tetlet.2020.151850
13. Shaw, K.; Niyogi, S.; Nandi, R.; Bisai, V. Tetrahedron Lett. 2020, 61, 152169. doi:10.1016/j.tetlet.2020.152169

14. Gottumukkala, A. L.; Matcha, K.; Lutz, M.; de Vries, J. G.; Minnaard, A. J. Chem. - Eur. J. 2012, 18, 6907-6914. doi:10.1002/chem.201200694

15. Buter, J.; Moezelaar, R.; Minnaard, A. J. Org. Biomol. Chem. 2014, 12, 5883-5890. doi:10.1039/c4ob01085j

16. Buter, J.; Heijnen, D.; Vila, C.; Hornillos, V.; Otten, E.; Giannerini, M.; Minnaard, A. J.; Feringa, B. L. Angew. Chem., Int. Ed. 2016, 55, 3620-3624. doi:10.1002/anie.201510328

17. Defieber, C.; Paquin, J.-F.; Serna, S.; Carreira, E. M. Org. Lett. 2004, 6, 3873-3876. doi:10.1021/ol048240x

18. Kurihara, K.; Sugishita, N.; Oshita, K.; Piao, D.; Yamamoto, Y.; Miyaura, N. J. Organomet. Chem. 2007, 692, 428-435. doi:10.1016/j.jorganchem.2006.04.042

19. Shintani, R.; Tsutsumi, Y.; Nagaosa, M.; Nishimura, T.; Hayashi, T. J. Am. Chem. Soc. 2009, 131, 13588-13589. doi:10.1021/ja905432x

20. Hahn, B. T.; Tewes, F.; Fröhlich, R.; Glorius, F. Angew. Chem., Int. Ed. 2010, 49, 1143-1146. doi:10.1002/anie.200905712

21. Chen, G.; Gui, J.; Li, L.; Liao, J. Angew. Chem., Int. Ed. 2011, 50, 7681-7685. doi:10.1002/anie.201102586

22. Thaler, T.; Guo, L.-N.; Steib, A. K.; Raducan, M.; Karaghiosoff, K.; Mayer, P.; Knochel, P. Org. Lett. 2011, 13, 3182-3185. doi:10.1021/ol200841x

23. Yasukawa, T.; Miyamura, H.; Kobayashi, S. J. Am. Chem. Soc. 2012, 134, 16963-16966. doi:10.1021/ja307913e

24. Shen, G.; Osako, T.; Nagaosa, M.; Uozumi, Y. J. Org. Chem. 2018, 83, 7380-7387. doi:10.1021/acs.joc.8b00178

25. Gutnov, A. Eur. J. Org. Chem. 2008, 4547-4554. doi:10.1002/ejoc.200800541

26. Miyaura, N. Synlett 2009, 2039-2050. doi:10.1055/s-0029-1217555

27. Shockley, S. E.; Holder, J. C.; Stoltz, B. M. Org. Process Res. Dev. 2015, 19, 974-981. doi:10.1021/acs.oprd.5b00169

28. Yang, G.; Zhang, W. Chem. Soc. Rev. 2018, 47, 1783-1810. doi:10.1039/c7cs00615b

29. Wu, L.; Shen, J.; Yang, G.; Zhang, W. Tetrahedron Lett. 2018, 59, 4055-4062. doi:10.1016/j.tetlet.2018.10.013

30. Li, W.; Zhang, J. Adv. Organomet. Chem. 2020, 74, 325-403. doi:10.1016/bs.adomc.2020.01.001

31. Wang, Z. Org. Chem. Front. 2020, 7, 3815-3841. doi:10.1039/d0qo00763c

32. Nishikata, T.; Yamamoto, Y.; Miyaura, N. Chem. Lett. 2005, 34, 720-721. doi:10.1246/cl.2005.720

33. Nishikata, T.; Yamamoto, Y.; Gridnev, I. D.; Miyaura, N. Organometallics 2005, 24, 5025-5032. doi:10.1021/om050678t

34. Nishikata, T.; Yamamoto, Y.; Miyaura, N. Adv. Synth. Catal. 2007, 349, 1759-1764. doi:10.1002/adsc.200600622

35. Yamamoto, Y.; Nishikata, T.; Miyaura, N. Pure Appl. Chem. 2008, 80, 807-817. doi:10.1351/pac200880050807

36. Nishikata, T.; Kobayashi, Y.; Kobayshi, K.; Yamamoto, Y.; Miyaura, N. Synlett 2007, 3055-3057. doi:10.1055/s-2007-990964

37. Gini, F.; Hessen, B.; Minnaard, A. J. Org. Lett. 2005, 7, 5309-5312. doi:10.1021/ol052222d

38. Hu, X.; Yang, X.; Dai, X.-J.; Li, C.-J. Adv. Synth. Catal. 2017, 359, 2402-2406. doi:10.1002/adsc.201700277

39. Suzuma, Y.; Yamamoto, T.; Ohta, T.; Ito, Y. Chem. Lett. 2007, 36, 470-471. doi:10.1246/cl.2007.470

40. Suzuma, Y.; Hayashi, S.; Yamamoto, T.; Oe, Y.; Ohta, T.; Ito, Y. Tetrahedron: Asymmetry 2009, 20, 2751-2758. doi:10.1016/j.tetasy.2009.11.025 
41. Poláčková, V.; Bariak, V.; Šebesta, R.; Toma, Š. Chem. Pap. 2011, 65, 338-344. doi:10.2478/s11696-011-0016-3

42. Morisaki, Y.; Imoto, H.; Hirano, K.; Hayashi, T.; Chujo, Y. J. Org. Chem. 2011, 76, 1795-1803. doi:10.1021/j01024442

43. Wong, J.; Gan, K.; Chen, H. J.; Pullarkat, S. A. Adv. Synth. Catal. 2014, 356, 3391-3400. doi:10.1002/adsc.201400473

44. Zhang, T.; Shi, M. Chem. - Eur. J. 2008, 14, 3759-3764. doi:10.1002/chem.200701982

45. Xu, Q.; Zhang, R.; Zhang, T.; Shi, M. J. Org. Chem. 2010, 75, 3935-3937. doi:10.1021/j01006224

46. Mullick, A. B.; Jeletic, M. S.; Powers, A. R.; Ghiviriga, I.; Abboud, K. A.; Veige, A. S. Polyhedron 2013, 52, 810-819. doi:10.1016/j.poly.2012.07.046

47. Kikushima, K.; Holder, J. C.; Gatti, M.; Stoltz, B. M. J. Am. Chem. Soc. 2011, 133, 6902-6905. doi:10.1021/ja200664x

48. Holder, J. C.; Zou, L.; Marziale, A. N.; Liu, P.; Lan, Y.; Gatti, M.; Kikushima, K.; Houk, K. N.; Stoltz, B. M. J. Am. Chem. Soc. 2013, 135, 14996-15007. doi:10.1021/ja401713g

49. Holder, J. C.; Goodman, E. D.; Kikushima, K.; Gatti, M.; Marziale, A. N.; Stoltz, B. M. Tetrahedron 2015, 71, 5781-5792. doi:10.1016/j.tet.2014.11.048

50. Holder, J. Org. Synth. 2015, 92, 247-266. doi:10.15227/orgsyn.092.0247

51. Holder, J. C.; Marziale, A. N.; Gatti, M.; Mao, B.; Stoltz, B. M. Chem. - Eur. J. 2013, 19, 74-77. doi:10.1002/chem.201203643

52. Boeser, C. L.; Holder, J. C.; Taylor, B. L. H.; Houk, K. N.; Stoltz, B. M.; Zare, R. N. Chem. Sci. 2015, 6, 1917-1922. doi:10.1039/c4sc03337j

53. Ochi, S.; Xia, Y.; Dong, G. Bull. Chem. Soc. Jpn. 2020, 93, 1213-1217. doi:10.1246/bcsj.20200147

54. Van Zeeland, R.; Stanley, L. M. ACS Catal. 2015, 5, 5203-5206. doi:10.1021/acscatal.5b01272

55. Kadam, A. A.; Ellern, A.; Stanley, L. M. Org. Lett. 2017, 19 , 4062-4065. doi:10.1021/acs.orglett.7b01825

56. Lestini, E.; Blackman, L. D.; Zammit, C. M.; Chen, T.; Williams, R. J.; Inam, M.; Couturaud, B.; O'Reilly, R. K. Polym. Chem. 2018, 9 , 820-823. doi:10.1039/c7py02050c

57. Bartáček, J.; Váňa, J.; Drabina, P.; Svoboda, J.; Kocúrik, M.; Sedlák, M. React. Funct. Polym. 2020, 153, 104615. doi:10.1016/j.reactfunctpolym.2020.104615

58. Zhou, L.; Qiu, J.; Wang, M.; Xu, Z.; Wang, J.; Chen, T. J. Inorg. Organomet. Polym. Mater. 2020, 30, 4569-4577. doi:10.1007/s10904-020-01599-2

59. Lamb, C. J. C.; Vilela, F.; Lee, A.-L. Org. Lett. 2019, 21, 8689-8694. doi:10.1021/acs.orglett.9b03293

60. Lai, J.; Li, W.; Wei, S.; Li, S. Org. Chem. Front. 2020, 7, 2263-2268. doi:10.1039/d0qo00519c

61. Tamura, M.; Ogata, H.; Ishida, Y.; Takahashi, Y. Tetrahedron Lett. 2017, 58, 3808-3813. doi:10.1016/j.tetlet.2017.08.041

62. de Gracia Retamosa, M.; Álvarez-Casao, Y.; Matador, E.; Gómez, Á.; Monge, D.; Fernández, R.; Lassaletta, J. M. Adv. Synth. Catal. 2019, 361, 176-184. doi:10.1002/adsc.201801021

63. Baek, D.; Ryu, H.; Ryu, J. Y.; Lee, J.; Stoltz, B. M.; Hong, S. Chem. Sci. 2020, 11, 4602-4607. doi:10.1039/d0sc00412j

64. Roscales, S.; Ortega, V.; Csákÿ, A. G. J. Org. Chem. 2013, 78, 12825-12830. doi:10.1021/jo402262m

65. Gao, A.; Liu, X.-Y.; Ding, C.-H.; Hou, X.-L. Synlett 2017, 28 , 2829-2832. doi:10.1055/s-0036-1590742

66. Jordan-Hore, J. A.; Sanderson, J. N.; Lee, A.-L. Org. Lett. 2012, 14, 2508-2511. doi:10.1021/ol300794a
67. Heintz, P. M.; Schumacher, B. P.; Chen, M.; Huang, W.; Stanley, L. M. ChemCatChem 2019, 11, 4286-4290. doi:10.1002/cctc.201900894

68. Wahlers, J.; Maloney, M.; Salahi, F.; Rosales, A. R.; Helquist, P.; Norrby, P.-O.; Wiest, O. J. Org. Chem. 2021, 86, 5660-5667. doi:10.1021/acs.joc.1c00136

\section{License and Terms}

This is an Open Access article under the terms of the Creative Commons Attribution License (https://creativecommons.org/licenses/by/4.0). Please note that the reuse, redistribution and reproduction in particular requires that the author(s) and source are credited and that individual graphics may be subject to special legal provisions.

The license is subject to the Beilstein Journal of Organic Chemistry terms and conditions:

(https://www.beilstein-journals.org/bjoc/terms)

The definitive version of this article is the electronic one which can be found at: https://doi.org/10.3762/bjoc. 17.84 